\title{
Strontium isotopes in melt inclusions from Samoan basalts: Implications for heterogeneity in the Samoan plume
}

\author{
Matthew G. Jackson ${ }^{a, *}$, Stanley R. Hart ${ }^{b}$ \\ ${ }^{a}$ Massachusetts Institute of Technology-Woods Hole Oceanographic Institution Joint Program, Woods Hole, Massachusetts, 02543, USA \\ ${ }^{\mathrm{b}}$ Department of Geology and Geophysics, Woods Hole Oceanographic Institution, Woods Hole, Massachusetts, 02543, USA
}

Received 25 October 2005; received in revised form 22 February 2006; accepted 26 February 2006

Available online 19 April 2006

Editor: R.W. Carlson

\begin{abstract}
We measured ${ }^{87} \mathrm{Sr} /{ }^{86} \mathrm{Sr}$ ratios on 41 olivine-hosted melt inclusions from nine Samoan basalts using laser ablation multi-collector (LA-MC) ICPMS. ${ }^{87} \mathrm{Sr} /{ }^{86} \mathrm{Sr}$ ratios are corrected for mass bias after eliminating major isobaric interferences from Rb and $\mathrm{Kr}$. The external precision averages $\pm 320 \mathrm{ppm}(2 \sigma)$ for the ${ }^{87} \mathrm{Sr} /{ }^{86} \mathrm{Sr}$ ratios on natural Samoan basalt glass standards of a similar composition to the melt inclusions.

All of the Sr-isotope ratios measured by LA-MC-ICPMS on Samoan melt inclusions fall within the range measured on wholerocks using conventional methods. However, melt inclusions from two Samoan basalt bulk rock samples are extremely heterogeneous in ${ }^{87} \mathrm{Sr} /{ }^{86} \mathrm{Sr}(0.70459-0.70926)$, covering $70 \%$ of the variability observed in ocean island basalts worldwide and nearly all of the variability observed in the Samoan island chain $(0.7044-0.7089)$. Seven melt inclusions from a third high ${ }^{3} \mathrm{He} /{ }^{4} \mathrm{He}$ Samoan basalt are isotopically homogeneous and exhibit ${ }^{87} \mathrm{Sr} /{ }^{86} \mathrm{Sr}$ values from 0.70434 to 0.70469 .

Several melt inclusions yield ${ }^{87} \mathrm{Sr} /{ }^{86} \mathrm{Sr}$ ratios higher than their host rock, indicating that assimilation of oceanic crust and lithosphere is not the likely mechanism contributing to the isotopic variability in these melt inclusions. Additionally, none of the 41 melt inclusions analyzed exhibit ${ }^{87} \mathrm{Sr} /{ }^{86} \mathrm{Sr}$ ratios lower than the least radiogenic basalts in Samoa $\left({ }^{87} \mathrm{Sr} /{ }^{86} \mathrm{Sr}=0.7044\right)$, within the quoted external precision. This provides an additional argument against assimilation of oceanic crust and lithosphere as the source of the isotopic diversity in the melt inclusions.

The trace element and isotopic diversity in Samoan melt inclusions can be modeled by aggregated fractional melting of two sources: A high ${ }^{3} \mathrm{He} /{ }^{4} \mathrm{He}$ source and an EM2 (enriched mantle 2) source. Melts of these two sources mix to generate the isotopic diversity in the Samoan melt inclusions. However, the melt inclusions from a basalt with the highest ${ }^{3} \mathrm{He} /{ }^{4} \mathrm{He}$ ratios in Samoa exhibit no evidence of an enriched component, but can be modeled as melts of a pure high ${ }^{3} \mathrm{He} /{ }^{4} \mathrm{He}$ mantle source.
\end{abstract}

(C) 2006 Elsevier B.V. All rights reserved.

Keywords: ${ }^{87} \mathrm{Sr} /{ }^{86} \mathrm{Sr}$; laser ablation; MC-ICPMS; melt inclusion; Samoa; EM2; PHEM; FOZO

* Corresponding author. Tel.: +1 5082893490 ; fax: +1 5084572175.

E-mail address: mjackson@whoi.edu (M.G. Jackson).

\section{Introduction}

Ocean island basalts (OIBs) erupted at hotspots are thought to be the surface expression of buoyantly upwelling mantle plumes that sample the mantle's compositional heterogeneities at various depths and times 
$[1,2]$. The Samoan islands and seamounts, formed by a mantle plume impinging on the Pacific plate just north of the Tonga Trench, form a time-progressive hotspot track [3,4] which conforms reasonably well to Morgan's hotspot model [5]. Samoan lavas exhibit the highest ${ }^{87} \mathrm{Sr} /{ }^{86} \mathrm{Sr}$ ratios and the largest ${ }^{87} \mathrm{Sr} /{ }^{86} \mathrm{Sr}$ variation (0.7044-0.7089) measured in fresh OIBs [4,6], making them ideal for prospecting for diverse Sr-isotope compositions in melt inclusions.

Olivine-hosted melt inclusions in Samoan lavas provide snapshots of diverse magma chemistry before complete melt aggregation, providing an opportunity to see more of the isotopic heterogeneity which exists in the melt source but that is not detectable in whole rocks. However, the chemical variability in melt inclusions may be generated by a number of processes that obscure source variation, including pre-entrapment fractional crystallization, post-entrapment diffusive reequilibration, crustal assimilation, and degree, type and depth of melting [7-16].

Studies delineating $\mathrm{Pb}$-isotope diversity in melt inclusions have demonstrated that heterogeneous melt source compositions are an important factor in generating compositional variability [17-21]. A landmark $\mathrm{Pb}-$ isotope study of melt inclusions hosted in basalts from Mangaia Island in the Cook Islands revealed significantly more isotopic heterogeneity than is found in whole rocks from the island [17]. The results indicate the presence of an unradiogenic $\mathrm{Pb}$-isotope endmember in the melt inclusions not discernable in whole-rock basalts. Problematically, this unradiogenic $\mathrm{Pb}$ endmember has been poorly characterized, owing partly to the large uncertainties associated with in situ $\mathrm{Pb}$-isotope measurements: $\mathrm{Pb}$-isotope data from melt inclusions generally are limited to ${ }^{208} \mathrm{~Pb} /{ }^{206} \mathrm{~Pb}$ versus ${ }^{207} \mathrm{~Pb} /{ }^{206} \mathrm{~Pb}$ isotope projections (due to the inability to collect precise ${ }^{204} \mathrm{~Pb}$ data on silicate melt inclusions), which place DMM (depleted MORB mantle, low ${ }^{3} \mathrm{He} /{ }^{4} \mathrm{He}$, low ${ }^{87} \mathrm{Sr} /{ }^{86} \mathrm{Sr}$ ), FOZO (Focus Zone, high ${ }^{3} \mathrm{He} /{ }^{4} \mathrm{He}$, low ${ }^{87} \mathrm{Sr} /{ }^{86} \mathrm{Sr}$ ), PHEM (Primitive Helium Mantle, high ${ }^{3} \mathrm{He} /{ }^{4} \mathrm{He}$, middle-range ${ }^{87} \mathrm{Sr} /{ }^{86} \mathrm{Sr}$ ) and EM2 (enriched mantle 2, low ${ }^{3} \mathrm{He} /{ }^{4} \mathrm{He}$, high ${ }^{87} \mathrm{Sr} /{ }^{86} \mathrm{Sr}$ ) in such close graphical proximity that they cannot be unequivocally resolved. The true pedigree of the unradiogenic $\mathrm{Pb}$ endmember in Mangaia is still unknown, and could be similar to any of these four endmembers.

An advantage to the Sr-isotope system is that the EM2 endmember has dramatically higher ${ }^{87} \mathrm{Sr} /{ }^{86} \mathrm{Sr}$ ratios ( 0.7089) [4] than the DMM (0.7026) [22], PHEM (0.7045) [23] and FOZO (0.7030) [24] mantle endmembers, and can be readily differentiated from the three less radiogenic endmembers. PHEM hosts signif- icantly more radiogenic $\mathrm{Sr}$ than DMM and FOZO and is easily resolved from these two components. Unfortunately, DMM and FOZO exhibit similar ${ }^{87} \mathrm{Sr} /{ }^{86} \mathrm{Sr}$ ratios and it will be difficult to differentiate between these two components as potential sources of the isotopic diversity in melt inclusions.

We present Sr-isotope data from olivine-hosted melt inclusions recovered from Samoan basalts, some of which lie near the EM2 mantle endmember, with the goal of better understanding the puzzling unradiogenic component sampled by melt inclusions. To this end, we also contribute Sr-isotope data measured on melt inclusions from a recently discovered high ${ }^{3} \mathrm{He} /{ }^{4} \mathrm{He}$ basalt from Samoa [25]. Our strategy is to analyze $\mathrm{Sr}$ isotopes in melt inclusions from EM2 and high ${ }^{3} \mathrm{He} /$ ${ }^{4} \mathrm{He}$ endmember basalts from Samoa, to constrain the role of the various components-EM2, PHEM, DMM and FOZO-that may be contributing to the Sr-isotope diversity in the Samoan plume.

\section{Methods}

A detailed description of the protocol used for in situ measurement of Sr isotopes in basaltic glasses (and melt inclusions) by LA-MC-ICPMS is provided in the Supplementary data. In order to measure Sr-isotope ratios in situ, we use a $213 \mathrm{~nm}$ NewWave laser ablation system coupled to a Themo-Finnigan Neptune MC-ICPMS, located in the Plasma Facility at Woods Hole Oceanographic Institution (WHOI). During analytical runs, the laser is run in aperture mode with $100 \%$ power, a pulse rate of $20 \mathrm{~Hz}$ and a spot size of $120 \mu \mathrm{m}$. The raster pattern varies depending on the size and shape of the melt inclusion, and the line speed is $4 \mu \mathrm{m} / \mathrm{s}$. Surface contamination is removed by pre-ablation using the same raster and spot size, but with a pulse rate of $5 \mathrm{~Hz}$, $45 \%$ power and a raster speed of $30 \mu \mathrm{m} / \mathrm{s}$.

During each analytical session, we measure intensities on masses 82 through 88 . Raw data are exported to an offline data correction program (TweaKr) for correcting the $\mathrm{Rb}$ and $\mathrm{Kr}$ isobaric interferences. Runs with low intensities (i.e., $<1 \mathrm{~V}$ on mass 88 , due to small size or low $\mathrm{Sr}$ content) were discarded as they are prone to large systematic errors [26]. Masses 85 and 88 are pure $\mathrm{Rb}$ and $\mathrm{Sr}$, respectively, with no significant known interferences, and require correction only for mass fractionation. We correct for $\mathrm{Kr}$ interferences on masses 84 and 86 so that the mass fractionation-corrected ${ }^{84} \mathrm{Sr} /{ }^{86} \mathrm{Sr}$ value is canonical $(0.0565725)$. The protocol for correcting mass 87 for the $\mathrm{Rb}$ interference is the following: $\mathrm{A}$ Samoan basalt glass with known ${ }^{87} \mathrm{Sr} /{ }^{86} \mathrm{Sr}$, from analysis by conventional Thermal Ionization Mass Spectrometry 
Table 1

Corrected and normalized ${ }^{87} \mathrm{Sr} /{ }^{86} \mathrm{Sr}$ melt inclusion and whole-rock data, including $\mathrm{Rb} / \mathrm{Sr}$ ratios and raw exported Neptune data (in volts)

\begin{tabular}{|c|c|c|c|c|c|c|c|c|c|c|c|c|c|c|c|c|c|}
\hline $\begin{array}{l}\text { Sample name } \\
\text { and grain \# }\end{array}$ & $\begin{array}{l}\text { Disc } \\
\#\end{array}$ & $\begin{array}{l}\text { Mass } 82 \\
\text { meas'd-V }\end{array}$ & $\begin{array}{l}\text { Mass } 83 \\
\text { meas'd-V }\end{array}$ & $\begin{array}{l}\text { Mass } 84 \\
\text { meas'd-V }\end{array}$ & $\begin{array}{l}\text { Mass } 85 \\
\text { meas'd-V }\end{array}$ & $\begin{array}{l}\text { Mass } 86 \\
\text { meas'd-V }\end{array}$ & $\begin{array}{l}\text { Mass } 87 \\
\text { meas'd-V }\end{array}$ & $\begin{array}{l}\text { Mass } 88 \\
\text { meas'd-V }\end{array}$ & $\begin{array}{l}{ }^{85} \mathrm{Rb} /{ }^{87} \mathrm{Rb} \\
\text { required }\end{array}$ & $\begin{array}{l}{ }^{87} \mathrm{Sr} /{ }^{86} \mathrm{Sr} \\
\text { corr'd }^{\mathrm{a}}\end{array}$ & $\begin{array}{l}{ }^{87} \mathrm{Sr} /{ }^{86} \mathrm{Sr} \\
\text { corr'd }^{\mathrm{b}}\end{array}$ & $\begin{array}{l}\text { Int. } \\
\text { prec. }\end{array}$ & $\mathrm{Rb} / \mathrm{Sr}$ & $\begin{array}{l}\text { Int. } \\
\text { prec. }\end{array}$ & $\begin{array}{l}\# \\
\text { Cycles } \\
\end{array}$ & Type & $\begin{array}{l}\text { Oliv } \\
\text { Fo } \\
\end{array}$ \\
\hline $\begin{array}{l}\text { AVON3-78-1 } \\
\text { (whole rock): }\end{array}$ & & & & & & & & & & & 0.70890 & & 0.1255 & & & & \\
\hline $78-1 Z$ & Year1 & 0.0013 & 0.0011 & 0.0193693 & 0.158083 & 0.263023 & 0.250903 & 2.25759 & 2.58966 & 0.70791 & 0.70784 & 87 & 0.0746 & 1.82 & $14^{\mathrm{c}}$ & $\mathrm{C}$ & 84.6 \\
\hline $78-1 \# 7^{\mathrm{d}}$ & Disc1 & 0.0020 & 0.0022 & 0.0193323 & 0.164332 & 0.188415 & 0.199670 & 1.60867 & 2.58811 & 0.70927 & 0.70926 & 123 & 0.1081 & 2.47 & 9 & $\mathrm{H}$ & 84.6 \\
\hline $78-1 \# 9^{d}$ & Disc1 & 0.0019 & 0.0021 & 0.0178511 & 0.111482 & 0.163039 & 0.159876 & 1.38845 & 2.58811 & 0.70733 & 0.70732 & 103 & 0.0850 & 1.90 & 6 & $\mathrm{H}$ & 84.4 \\
\hline $78-1 \# 6^{\mathrm{d}}$ & Disc2 & 0.0031 & 0.0034 & 0.0297219 & 0.341900 & 0.308400 & 0.354647 & 2.62064 & 2.58593 & 0.70846 & 0.70843 & 99 & 0.1397 & 2.63 & 32 & $\mathrm{H}$ & 83.6 \\
\hline $78-1 \# 9^{d}$ & Disc2 & 0.0031 & 0.0034 & 0.0316443 & 0.384820 & 0.340724 & 0.395010 & 2.89882 & 2.58593 & 0.70873 & 0.70870 & 94 & 0.1421 & 3.08 & 30 & $\mathrm{H}$ & 82.8 \\
\hline $78-1 \# 10^{\mathrm{d}}$ & Disc2 & 0.0030 & 0.0031 & 0.0241696 & 0.094343 & 0.202069 & 0.179689 & 1.70410 & 2.58663 & 0.70845 & 0.70842 & 104 & 0.0593 & 3.21 & 16 & $\mathrm{H}$ & 83.6 \\
\hline $78-1 \# 4^{\mathrm{d}}$ & Disc3 & 0.0049 & 0.0057 & 0.0638080 & 0.704962 & 0.756968 & 0.817352 & 6.43584 & 2.58694 & 0.70869 & 0.70866 & 44 & 0.1179 & 0.60 & 40 & G & 85.2 \\
\hline 78-1inside & Disc3 & 0.0048 & 0.0049 & 0.0311385 & 0.155536 & 0.152840 & 0.165959 & 1.25071 & 2.58564 & 0.70689 & 0.70686 & 139 & 0.1337 & 2.20 & 16 & $\mathrm{C}$ & 84.3 \\
\hline $78-1 B$ & Disc3 & 0.0044 & 0.0043 & 0.0327454 & 0.189114 & 0.222802 & 0.230356 & 1.86119 & 2.58675 & 0.70791 & 0.70788 & 127 & 0.1089 & 5.76 & 10 & $\mathrm{C}$ & 84.2 \\
\hline $78-1 \mathrm{C}$ & Disc3 & 0.0041 & 0.0043 & 0.0408646 & 0.414636 & 0.401444 & 0.448986 & 3.40453 & 2.58675 & 0.70866 & 0.70863 & 38 & 0.1304 & 1.96 & 24 & $\mathrm{C}$ & 83.9 \\
\hline $78-1 \mathrm{D}$ & Disc3 & 0.0048 & 0.0048 & 0.0313504 & 0.130366 & 0.156852 & 0.158811 & 1.28485 & 2.58675 & 0.70699 & 0.70696 & 119 & 0.1091 & 3.79 & 14 & $\mathrm{C}$ & 85.3 \\
\hline $\begin{array}{l}\text { AVON3-71-2 } \\
\quad \text { (whole rock): }\end{array}$ & & & & & & & & & & & 0.70594 & & 0.0754 & & & & \\
\hline $71-2 C^{d}$ & Year1 & 0.0015 & 0.0012 & 0.0241555 & 0.131881 & 0.348997 & 0.301171 & 2.99950 & 2.58977 & 0.70488 & 0.70481 & 50 & 0.0469 & 4.99 & $10^{\mathrm{c}}$ & G & 88.8 \\
\hline $71-2 C^{\mathrm{e}}$ & Disc3 & 0.0049 & 0.0051 & 0.0423813 & 0.151006 & 0.357484 & 0.309961 & 3.00928 & 2.58772 & 0.70487 & 0.70484 & 60 & 0.0539 & 2.09 & 19 & $\mathrm{G}$ & 88.8 \\
\hline $71-2 \mathrm{Da}$ & Year1 & 0.0014 & 0.0012 & 0.0190549 & 0.143364 & 0.258958 & 0.241512 & 2.22256 & 2.58977 & 0.70555 & 0.70549 & 53 & 0.0687 & 3.92 & $12^{\mathrm{c}}$ & $\mathrm{C}$ & 90.1 \\
\hline $71-2 \mathrm{i} \_\mathrm{mi}^{\mathrm{d}}$ & Disc1 & 0.0041 & 0.0042 & 0.0293387 & 0.151118 & 0.188888 & 0.190950 & 1.57393 & 2.58696 & 0.70605 & 0.70602 & 42 & 0.1028 & 0.89 & 19 & G & 90.7 \\
\hline 71-2\#6_saol1 & Disc1 & 0.0040 & 0.0044 & 0.0392836 & 0.237282 & 0.399731 & 0.376067 & 3.39132 & 2.58675 & 0.70532 & 0.70529 & 63 & 0.0750 & 2.45 & 32 & $\mathrm{C}$ & 90.3 \\
\hline 71-2\#6_saol2 & Disc1 & 0.0038 & 0.0039 & 0.0311684 & 0.151330 & 0.259691 & 0.241924 & 2.18859 & 2.58675 & 0.70511 & 0.70508 & 90 & 0.0741 & 3.15 & 15 & $\mathrm{C}$ & 90.5 \\
\hline 71-2pentagon & Disc1 & 0.0035 & 0.0036 & 0.0274768 & 0.164455 & 0.221630 & 0.220515 & 1.86556 & 2.58653 & 0.70603 & 0.70600 & 69 & 0.0944 & 1.40 & 35 & $\mathrm{C}$ & 91.1 \\
\hline $71-2 \# 5^{d}$ & Disc3 & 0.0049 & 0.0055 & 0.0608667 & 0.440578 & 0.704362 & 0.672560 & 5.98503 & 2.58694 & 0.70537 & 0.70534 & 34 & 0.0792 & 1.23 & 40 & G & 91.0 \\
\hline $71-2 \# 5^{\mathrm{e}}$ & Disc3 & 0.0049 & 0.0057 & 0.0600272 & 0.456791 & 0.688053 & 0.667289 & 5.84446 & 2.58694 & 0.70537 & 0.70534 & 34 & 0.0841 & 1.21 & 40 & G & 91.0 \\
\hline $71-2 \# 6^{\mathrm{d}}$ & Disc3 & 0.0050 & 0.0053 & 0.0461581 & 0.261970 & 0.420138 & 0.399032 & 3.54513 & 2.58674 & 0.70602 & 0.70600 & 53 & 0.0794 & 1.35 & 40 & G & 85.7 \\
\hline $71-2 \# 6^{\mathrm{e}}$ & Disc3 & 0.0050 & 0.0054 & 0.0511361 & 0.320998 & 0.514222 & 0.489758 & 4.35389 & 2.58674 & 0.70600 & 0.70598 & 32 & 0.0793 & 1.19 & 40 & G & 85.7 \\
\hline $71-2 Z$ & Disc3 & 0.0041 & 0.0042 & 0.0286629 & 0.120538 & 0.176062 & 0.169532 & 1.46336 & 2.58809 & 0.70576 & 0.70573 & 97 & 0.0882 & 2.60 & 21 & $\mathrm{C}$ & 86.1 \\
\hline $71-2 \mathrm{~N}$ & Disc 3 & 0.0041 & 0.0043 & 0.0326106 & 0.171904 & 0.249420 & 0.242412 & 2.09517 & 2.58778 & 0.70554 & 0.70551 & 48 & 0.0879 & 2.74 & 26 & $\mathrm{C}$ & 90.5 \\
\hline 71-2imi_run2 & Disc3 & 0.0046 & 0.0048 & 0.0392641 & 0.162916 & 0.326152 & 0.292704 & 2.74335 & 2.58778 & 0.70520 & 0.70518 & 112 & 0.0638 & 2.80 & 12 & $\mathrm{C}$ & 91.0 \\
\hline $71-2 \mathrm{~V}$ & Disc3 & 0.0034 & 0.0037 & 0.0358138 & 0.196791 & 0.370738 & 0.339729 & 3.15166 & 2.58754 & 0.70461 & 0.70459 & 122 & 0.0668 & 4.32 & 13 & $\mathrm{C}$ & 87.4 \\
\hline $\begin{array}{l}\text { OFU-04-06 } \\
\quad \text { (whole rock): }\end{array}$ & & & & & & & & & & & 0.70458 & & 0.0458 & & & & \\
\hline OFU-04-06-13 & Ofu & 0.0012 & 0.0004 & 0.0123598 & 0.087599 & 0.202878 & 0.179279 & 1.74009 & 2.58774 & 0.70458 & 0.70457 & 226 & 0.0541 & 6.04 & 6 & $\mathrm{H}$ & 79.8 \\
\hline OFU-04-06-15 & Ofu & 0.0008 & 0.0006 & 0.0166800 & 0.116272 & 0.260130 & 0.231639 & 2.23575 & 2.58791 & 0.70443 & 0.70443 & 128 & 0.0556 & 1.62 & 13 & $\mathrm{H}$ & 77.3 \\
\hline
\end{tabular}




\begin{tabular}{|c|c|c|c|c|c|c|c|c|c|c|c|c|c|c|c|c|c|}
\hline OFU-04-06- $25^{\mathrm{d}}$ & Ofu & 0.0009 & 0.0008 & 0.0272537 & 0.215485 & 0.450579 & 0.407078 & 3.87445 & 2.58797 & 0.70455 & 0.70454 & 60 & 0.0595 & 3.24 & 20 & $\mathrm{H}$ & 77.2 \\
\hline OFU-04-06-26 ${ }^{\mathrm{d}}$ & Ofu & 0.0007 & 0.0006 & 0.0135577 & 0.076760 & 0.200599 & 0.173323 & 1.72195 & 2.58771 & 0.70443 & 0.70443 & 86 & 0.0476 & 2.73 & 16 & $\mathrm{H}$ & 76.5 \\
\hline OFU-04-06-28 & Ofu & 0.0007 & 0.0006 & 0.0138764 & 0.082936 & 0.207139 & 0.180426 & 1.77796 & 2.58777 & 0.70435 & 0.70434 & 164 & 0.0499 & 1.97 & 11 & $\mathrm{H}$ & 78.4 \\
\hline OFU-04-06-03 ${ }^{\mathrm{d}}$ & Ofu & 0.0004 & 0.0005 & 0.0090473 & 0.057761 & 0.131245 & 0.115793 & 1.11700 & 2.58747 & 0.70443 & 0.70443 & 92 & 0.0560 & 2.67 & 15 & $\mathrm{H}$ & 83.8 \\
\hline OFU-04-06-02 ${ }^{\mathrm{d}}$ & Ofu & 0.0007 & 0.0006 & 0.0126725 & 0.082453 & 0.187441 & 0.166696 & 1.61548 & 2.58588 & 0.70469 & 0.70469 & 184 & 0.0542 & 0.96 & 7 & $\mathrm{H}$ & 76.5 \\
\hline $\begin{array}{l}\text { AVON3-71-11 } \\
\quad \text { (whole rock): }\end{array}$ & & & & & & & & & & & 0.70550 & & 0.0700 & & & & \\
\hline $71-11 a^{d}$ & Disc1 & 0.0035 & 0.0035 & 0.0250240 & 0.083017 & 0.152405 & 0.138888 & 1.27387 & 2.58654 & 0.70653 & 0.70653 & 83 & 0.0691 & 1.22 & 16 & G & 83.0 \\
\hline $71-11 a^{e}$ & Disc1 & 0.0019 & 0.0021 & 0.0204900 & 0.125897 & 0.216562 & 0.204083 & 1.85257 & 2.58857 & 0.70692 & 0.70692 & 109 & 0.0720 & 0.92 & 15 & $\mathrm{G}$ & 83.0 \\
\hline $71-11 \# 1^{\mathrm{d}}$ & Disc3 & 0.0048 & 0.0048 & 0.0316250 & 0.103649 & 0.160366 & 0.150752 & 1.31592 & 2.58772 & 0.70683 & 0.70680 & 144 & 0.0846 & 5.70 & 8 & $\mathrm{G}$ & 81.4 \\
\hline $\begin{array}{l}\text { AVON3-68-3 } \\
\text { (whole rock): }\end{array}$ & & & & & & & & & & & 0.70539 & & 0.0688 & & & & \\
\hline $68-3 \# 6 \mathrm{mil}^{\mathrm{d}}$ & Disc1 & 0.0020 & 0.0021 & 0.0186133 & 0.117638 & 0.165627 & 0.163878 & 1.40909 & 2.58798 & 0.70625 & 0.70624 & 75 & 0.0884 & 3.01 & 20 & G & 87.9 \\
\hline $68-3 \# 6 \mathrm{mi} 2$ & Disc1 & 0.0038 & 0.0040 & 0.0305189 & 0.209211 & 0.258789 & 0.264567 & 2.18215 & 2.58653 & 0.70577 & 0.70575 & 87 & 0.1027 & 1.92 & 12 & $\mathrm{C}$ & 87.9 \\
\hline $68-3 \# 6 \mathrm{mi}^{\mathrm{e}}$ & Disc1 & 0.0037 & 0.0041 & 0.0371899 & 0.294848 & 0.389761 & 0.392493 & 3.31142 & 2.58653 & 0.70577 & 0.70574 & 93 & 0.0954 & 1.73 & 9 & $\mathrm{C}$ & 87.9 \\
\hline 68-3Ami & Disc3 & 0.0041 & 0.0042 & 0.0302365 & 0.092078 & 0.197293 & 0.173102 & 1.64414 & 2.58754 & 0.70482 & 0.70480 & 144 & 0.0600 & 6.45 & 10 & $\mathrm{C}$ & 90.1 \\
\hline $\begin{array}{l}\text { AVON3-63-2 } \\
\quad \text { (whole rock): }\end{array}$ & & & & & & & & & & & 0.70540 & & 0.0679 & & & & \\
\hline $63-2 \mathrm{mi}$ & Disc3 & 0.0049 & 0.0051 & 0.0641890 & 0.514757 & 0.759082 & 0.741869 & 6.46111 & 2.58815 & 0.70599 & 0.70596 & 58 & 0.0856 & 2.68 & 31 & $\mathrm{C}$ & - \\
\hline $63-2 \mathrm{mi}^{\mathrm{e}}$ & Disc3 & 0.0047 & 0.0056 & 0.0601701 & 0.544474 & 0.708353 & 0.718034 & 6.03171 & 2.58815 & 0.70616 & 0.70613 & 69 & 0.0969 & 1.22 & 36 & $\mathrm{C}$ & - \\
\hline 63-2ami & Disc3 & 0.0044 & 0.0045 & 0.0283814 & 0.086324 & 0.138106 & 0.128251 & 1.13104 & 2.58815 & 0.70522 & 0.70520 & 181 & 0.0818 & 4.84 & 11 & $\mathrm{C}$ & 87.1 \\
\hline 63-2bmil & Disc3 & 0.0044 & 0.0045 & 0.0334163 & 0.133112 & 0.234231 & 0.215648 & 1.95929 & 2.58815 & 0.70528 & 0.70525 & 55 & 0.0728 & 3.15 & 23 & $\mathrm{C}$ & 86.6 \\
\hline $\begin{array}{l}\text { AVON3-74-1 } \\
\quad \text { (whole rock): }\end{array}$ & & & & & & & & & & & 0.70469 & & 0.0484 & & & & \\
\hline $74-1 \mathrm{mi}$ & Year1 & 0.0015 & 0.0012 & 0.0174643 & 0.076749 & 0.224099 & 0.189719 & 1.91969 & 2.58895 & 0.70483 & 0.70477 & 157 & 0.0426 & 1.38 & $9^{c}$ & $\mathrm{C}$ & 85.1 \\
\hline $\begin{array}{l}\text { S11 (whole } \\
\text { rock): }\end{array}$ & & & & & & & & & & & 0.70620 & & 0.0597 & & & & \\
\hline $\mathrm{S} 11 \mathrm{mi}$ & Disc3 & 0.0048 & 0.0048 & 0.0330920 & 0.078499 & 0.189324 & 0.161268 & 1.56507 & 2.58564 & 0.70520 & 0.70518 & 125 & 0.0539 & 6.13 & 11 & $\mathrm{C}$ & 76.5 \\
\hline $\begin{array}{l}\text { AVON3-78-3 } \\
\quad \text { (whole rock): }\end{array}$ & & & & & & & & & & & 0.70889 & & 0.1108 & & & & \\
\hline $78-3 \mathrm{mi}$ & Year1 & 0.0014 & 0.0012 & 0.0184433 & 0.207247 & 0.241204 & 0.254752 & 2.06790 & 2.58966 & 0.70814 & 0.70807 & 61 & 0.1068 & 3.51 & $18^{\mathrm{c}}$ & $\mathrm{C}$ & 84.1 \\
\hline \multicolumn{18}{|c|}{ 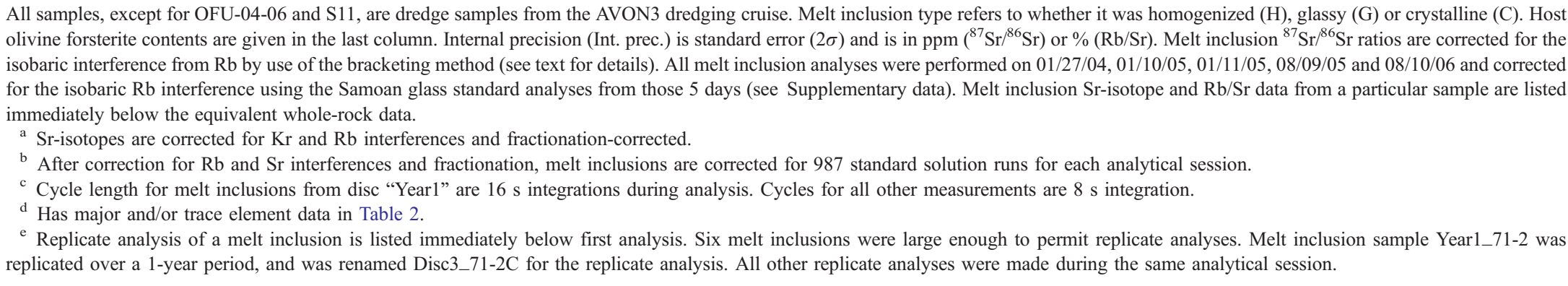 } \\
\hline
\end{tabular}


(TIMS), is measured by laser ablation, $\mathrm{Kr}$-corrected, and the ${ }^{85} \mathrm{Rb} /{ }^{87} \mathrm{Rb}$ ratio is adjusted until the known TIMS ${ }^{87} \mathrm{Sr} /{ }^{86} \mathrm{Sr}$ value of the glass is achieved. We adopted the strategy of using the required ${ }^{85} \mathrm{Rb} /{ }^{87} \mathrm{Rb}$ of the Samoan basalt glass standards to bracket the ${ }^{85} \mathrm{Rb} /$ ${ }^{87} \mathrm{Rb}$ of the basalt glass unknowns. In order to estimate the overall accuracy associated with this technique, we apply contiguous bracketing of the glass standard runs, and we are able to reproduce the known TIMS values to within an average of $\pm 320 \mathrm{ppm}$ ( $2 \sigma$ standard deviation). However, due to uncertainty associated with the ${ }^{85} \mathrm{Rb} /$ ${ }^{87} \mathrm{Rb}$ ratio $(2.5875 \pm 0.00275,2 \sigma)$, the final, corrected ${ }^{87} \mathrm{Sr} /{ }^{86} \mathrm{Sr}$ ratio exhibits an error magnification that is directly proportional to the $\mathrm{Rb} / \mathrm{Sr}$ ratio of the sample. Samples with low $\mathrm{Rb} / \mathrm{Sr}$ will exhibit less error from the $\mathrm{Rb}$ correction $(145 \mathrm{ppm}, \mathrm{Rb} / \mathrm{Sr}=0.04)$ than samples with high $\mathrm{Rb} / \mathrm{Sr}$ (505 ppm, $\mathrm{Rb} / \mathrm{Sr}=0.14$ ) (see Supplementary data). However, over the range of $\mathrm{Rb} / \mathrm{Sr}$ in the Samoan basalt glass standards (0.045-0.126), we find no relationship between the internal (in-run) precision of ${ }^{87} \mathrm{Sr} /{ }^{86} \mathrm{Sr}$ ratios (which average $45 \mathrm{ppm}$, 2ó standard deviation) and $\mathrm{Rb} / \mathrm{Sr}$ during analyses of basalt glasses by laser ablation. Similarly, there does not appear to be a relationship between $\mathrm{Kr} / \mathrm{Sr}$ and the internal precision or reproducibility (external precision) of the ${ }^{87} \mathrm{Sr} /{ }^{86} \mathrm{Sr}$ ratios in Samoan glass standards over the range of ratios that we have observed during melt inclusion analysis $\left({ }^{82} \mathrm{Kr} /{ }^{88} \mathrm{Sr}\right.$ from 0.00013 to 0.004$)$. Finally, the reproducibility of ${ }^{87} \mathrm{Sr} /{ }^{86} \mathrm{Sr}$ measurement does not appear to be related to $\mathrm{Sr}$ intensity over the range of $\mathrm{Sr}$ intensities observed in lasering Samoan glasses, a range that encompasses the melt inclusion analyses.

Six melt inclusions were large enough for replicate analysis (one melt inclusion, 71-2C, was replicated over a one-year period), and five of their ${ }^{87} \mathrm{Sr} /{ }^{86} \mathrm{Sr}$ ratios were reproducible within the quoted precision. However, the replicate analysis of melt inclusion 71-11a was different by $550 \mathrm{ppm}$ (see Table 1), while error resulting from the Rb correction is only $260 \mathrm{ppm}(2 \sigma)$ on Samoan glass standards with similar $\mathrm{Rb} / \mathrm{Sr}$ ratios. The internal precision of the replicate analysis of this melt inclusion was $\sim 100 \mathrm{ppm}(2 \sigma)$. Data from this melt inclusion indicates that larger-than-usual ${ }^{85} \mathrm{Rb} /{ }^{87} \mathrm{Rb}$ variations over time can occasionally generate uncertainties (above the $2 \sigma$ level) in ${ }^{87} \mathrm{Sr} /{ }^{86} \mathrm{Sr}$ that are somewhat larger than error predicted by the data from Samoan glass standards.

An upper limit for the ${ }^{87} \mathrm{Sr} /{ }^{86} \mathrm{Sr}$ measurement precision on Samoan melt inclusions with low $\mathrm{Rb} / \mathrm{Sr}$ can be inferred from the near-uniform ratios obtained on melt inclusions from the high ${ }^{3} \mathrm{He} /{ }^{4} \mathrm{He}$ Ofu basalt. $\mathrm{The} \mathrm{Rb} / \mathrm{Sr}$ values were among the lowest during analy- sis of Ofu melt inclusions, and the tight clustering of the Ofu melt inclusions may be partially explained by decreased error of ${ }^{87} \mathrm{Sr} /{ }^{86} \mathrm{Sr}$ measurement for these samples compared to other, higher $\mathrm{Rb} / \mathrm{Sr}$ Samoan glasses and melt inclusions from Vailulu'u and Malumalu. If we assume that the Ofu melt inclusions are isotopically homogeneous, then the external precision on these 7 melt inclusions is $\pm 335 \mathrm{ppm}(2 \sigma)$. Some of the apparent variability may be a result of error from the $\mathrm{Rb}$ correction, which is $\pm 190 \mathrm{ppm}(2 \sigma)$ at $\mathrm{Rb} / \mathrm{Sr}$ ratios of 0.053 , and may not reflect true variability. Additionally, internal precision varied from 60 to $226 \mathrm{ppm}$ ( $2 \sigma$ standard error) on the seven Ofu melt inclusions.

Masses 85 and 88 represent pure $\mathrm{Rb}$ and $\mathrm{Sr}$, respectively, so that fairly precise measurement of $\mathrm{Rb} / \mathrm{Sr}$ ratios can be generated. After correcting for mass fractionation $(\approx 1.5 \% / \mathrm{amu}), \mathrm{Rb} / \mathrm{Sr}$ ratios on Samoan basalt glasses measured by laser ablation are reproduceable to $17 \%$ ( $2 \sigma$, compared to ratios obtained by XRF/ICP techniques on the same samples), and precise $(1.7 \%, 2 \sigma)$ during multiple runs on the same glass (see Supplementary data).

Major element compositions of glassy and homogenized melt inclusions were obtained with a JEOL-733 automated electron microprobe at the Massachusetts Institute of Technology using an electron beam with current of $10 \mathrm{nA}$ and accelerating potential of $15 \mathrm{kV}$ focused to a spot of $1-2 \mu \mathrm{m}$ in diameter for olivine analyses, and defocused to $10 \mu \mathrm{m}$ for glass analyses. Trace element contents were determined with a Cameca IMS $3 \mathrm{f}$ ion microprobe following the techniques described in $[27,28]$. A small beam $(5 \mu \mathrm{m}$ diameter spot), combined with a high-energy filtering technique (80-100 eV window), was used to determine trace element concentrations. Precision for $\mathrm{Sr}, \mathrm{La}, \mathrm{Zr}, \mathrm{Y}$ is estimated to be $\pm 15 \%$, and $\pm 20-30 \%$ for $\mathrm{Ba}, \mathrm{Nb}$ and $\mathrm{Rb}$. Homogenization of olivine-hosted melt inclusions was performed in a furnace at 1187-1220 C (depending on olivine composition) at $1 \mathrm{~atm}$ pressure for $5 \mathrm{~min}$ in a graphite capsule.

To correct for the effects of crystallization of olivine in the glassy and homogenized melt inclusions, we add equilibrium olivine to the melt inclusions in $0.1 \%$ increments until equilibrium with mantle olivine $\left(\mathrm{Fo}_{90}\right)$ is achieved, assuming olivine-melt partitioning of $\mathrm{Fe}$ and $\mathrm{Mg}$ from [29]. Instead of correcting the melt inclusions to be in equilibrium with the host olivine, this correction scheme is chosen so that we can compare them to similarly corrected Samoan whole-rock lavas (after discarding data from the most evolved$\mathrm{MgO}<6.5$ wt.\%-whole-rock samples). 


\section{Results}

\subsection{Sr-isotope variability in melt inclusions}

Sr-isotopes were measured in melt inclusions from nine geochemically well-characterized basalt samples $[4,25]$ from five islands and seamounts located along the Samoan hotspot track. Olivines $\left(\mathrm{Fo}_{76-91}\right)$ with large ellipsoidal melt inclusions (50-250 $\mu \mathrm{m}$ diameter) were separated from the basalt samples for melt inclusion exposure and isotopic analysis. Most of the melt inclusions were crystalline and usually contained dendritic clinopyroxene in a glassy matrix, with spinel and rare sulfide globules; some $(\approx 5 \%)$ of the melt inclusions were glassy. The high ${ }^{3} \mathrm{He} /{ }^{4} \mathrm{He}$ basalt sample OFU-04-06 was unique in that amphibole and apatite were common melt inclusion phases, and carbonate was also observed.

Olivines $\left(\mathrm{Fo}_{82-85}\right)$ hosting melt inclusions were separated from Malumalu seamount dredge sample 781, a picrite with the highest ${ }^{87} \mathrm{Sr} /{ }^{86} \mathrm{Sr}$ ratio (0.7089) of any OIB [4]. Melt inclusion-rich olivines were also recovered from dredge sample 71-2 $\left(\mathrm{Fo}_{84-91}\right)$ from Vailulu'u, a seamount that displays intermediate enrichment relative to the other Samoan islands and seamounts (bulk rock ${ }^{87} \mathrm{Sr} /{ }^{86} \mathrm{Sr}$ isotope ratios from 0.7052 to $0.7067, n=20$ ). From Ofu Island, olivines $\left(\mathrm{Fo}_{76-84}\right)$ were recovered from ankaramite dike sample OFU-04-06, which exhibits the highest ${ }^{3} \mathrm{He} /{ }^{4} \mathrm{He}$ measured in a Samoan basalt [25]. Lavas from Ofu are the most isotopically homogeneous of the volcanoes in the Samoan chain $\left({ }^{87} \mathrm{Sr} /{ }^{86} \mathrm{Sr}\right.$ from 0.70444 to $0.70480, n=12$ ). Finally, a smaller number of olivines were separated for melt inclusion analysis from Vailulu'u dredge samples 71-11 (Fo F1-83 $\left._{81}\right)$ 63-2 $\left(\mathrm{Fo}_{86-87}\right)$ and 68-3 ( $\left.\mathrm{Fo}_{87-90}\right)$, Malumalu dredge sample 78-3 ( $\left.\mathrm{Fo}_{84}\right)$, Ta'u Island dredge sample $74-1\left(\mathrm{Fo}_{85}\right)$, and Savai'i subaerial post-erosional sample S11 ( $\left.\mathrm{Fo}_{76}\right)$.

The Sr-isotope data from melt inclusions in just three Samoan whole-rock samples (OFU-04-06, 78-1 and 712) define a broad array that encompasses the entire spectrum of Sr-isotope variability (0.70434-0.70926) recorded in Samoan basalts (Fig. 1 and Table 1). Eleven melt inclusions from $78-1$ display ${ }^{87} \mathrm{Sr} /{ }^{86} \mathrm{Sr}$ values of $0.70686-0.70926$, and encompass over $30 \%$ of the isotope variability observed in the OIB mantle. Vailulu'u melt inclusions from dredge samples 71-2 $\left({ }^{87} \mathrm{Sr} /{ }^{86} \mathrm{Sr}=0.70459-0.70602, n=12\right.$ melt inclusions $)$ and $68-3\left({ }^{87} \mathrm{Sr} /{ }^{86} \mathrm{Sr}=0.70480-0.70624, n=3\right)$ exhibit a smaller range of $\mathrm{Sr}$-isotope values than 78-1. However, the magnitude of the Sr-isotope heterogeneity in the melt inclusions from these two samples is approxi-
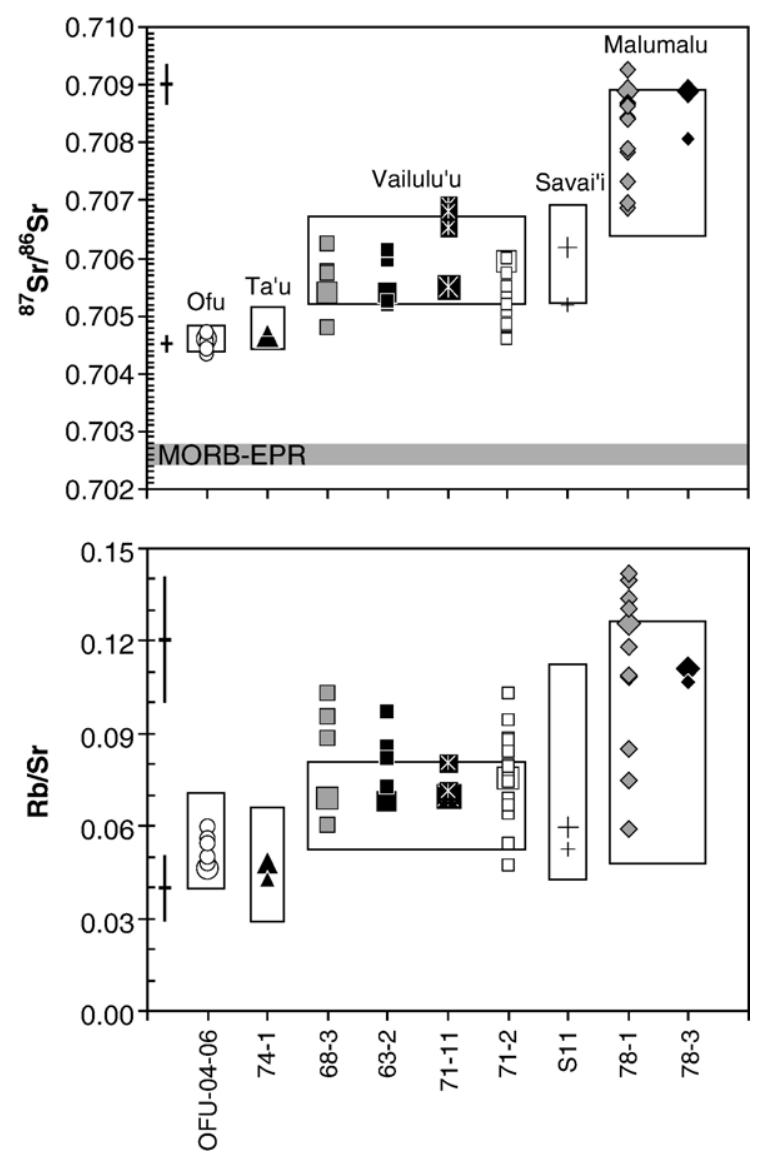

Fig. $1 .{ }^{87} \mathrm{Sr} /{ }^{86} \mathrm{Sr}$ (upper panel) and $\mathrm{Rb} / \mathrm{Sr}$ (lower panel) in melt inclusions from nine basalt samples compared to the total variation in each island/seamount (shown by boxes). References for whole-rock data can be found in [4]. The nine whole rocks from which the melt inclusions were separated are represented by larger symbols. No melt inclusions are more isotopically depleted than the most depleted lava measured in the island chain $\left({ }^{87} \mathrm{Sr} /{ }^{86} \mathrm{Sr}>0.7044\right)$. The range for EPR N-MORB [22] (averaged by segment) plots significantly below the Samoan whole rocks and melt inclusions. Replicate analyses on the same melt inclusion are averaged. The $\mathrm{Rb} / \mathrm{Sr}$ for Savai'i whole-rock sample SAV1-25 is not included because of alteration. Internal precision ( $2 \sigma$, standard error) for ${ }^{87} \mathrm{Sr} /{ }^{86} \mathrm{Sr}$ is approximately the size of the data symbols. ${ }^{87} \mathrm{Sr} /{ }^{86} \mathrm{Sr}$ error bars represent error propagated from the $\mathrm{Rb}$ correction, as determined on Samoan glass standards, and dominates the error associated with ${ }^{87} \mathrm{Sr} /{ }^{86} \mathrm{Sr}$ measurement by LAICP-MS; maximum and minimum (500 and $150 \mathrm{ppm}$ ) errors are shown for reference. Error bars for $\mathrm{Rb} / \mathrm{Sr}$ are $\pm 17 \%(2 \sigma$, standard deviation), and are based on the reproduceability of $\mathrm{Rb} / \mathrm{Sr}$ measurement on Samoan glass standards; internal precision for $\mathrm{Rb} / \mathrm{Sr}$ averages an order of magnitude better. Samples are listed in order of increasing whole-rock ${ }^{87} \mathrm{Sr} /{ }^{86} \mathrm{Sr}$, from left to right.

mately equal to the variability observed in Vailulu'u seamount lavas, although the melt inclusions sample a more depleted component than observed in whole rocks from this seamount. Among the Vailulu'u samples, only sample 71-11 $\left({ }^{87} \mathrm{Sr} /{ }^{86} \mathrm{Sr}=0.70653-0.70692, n=2\right)$ 
hosts inclusions that sample compositions similar to the most enriched isotopic compositions observed in Vailulu'u volcano. Like sample 71-11, isotopic analyses of melt inclusions from sample $63-2\left({ }^{87} \mathrm{Sr} /\right.$ $\left.{ }^{86} \mathrm{Sr}=0.70520-0.70613, n=3\right)$ lie completely within the isotopic range found in the whole rocks from Vailulu'u seamount. OFU-04-06 melt inclusions exhibit the least isotopic variability $\left({ }^{87} \mathrm{Sr} /{ }^{86} \mathrm{Sr}=0.70434-\right.$ $0.70469, n=7$ ) among the samples with isotopic analyses on more than two different inclusions, and this variability is similar to the variability sampled by whole-rock lavas from the island. There is only a single melt inclusion analysis from each of basalt samples 783 (0.70807), 74-1 (0.70477) and S11 (0.70518); the Srisotope ratios lie within the range observed in the respective host volcanoes.

Although melt inclusions show more depleted isotopic compositions than the island or seamount from which they were recovered, they are not observed to sample compositions more depleted than whole rocks from the Samoan hotspot $\left({ }^{87} \mathrm{Sr} /{ }^{86} \mathrm{Sr} \geq 0.7044\right)$. Therefore, the least radiogenic Sr-isotope ratios in Samoan basalts and melt inclusions are significantly more enriched than the depleted upper mantle sampled by MORB along the EPR (East Pacific Rise; 0.702280.70287, N-MORB segment averages from [22]); the old oceanic crust upon which the Samoan island chain is constructed is probably isotopically similar to these modern EPR basalts.

$\mathrm{Rb} / \mathrm{Sr}$ ratios measured by LA-ICP MS on the same set of melt inclusions tell a story similar to that of the isotopes. Melt inclusions in sample 78-1 exhibit the largest variation in $\mathrm{Rb} / \mathrm{Sr}$ ratios (0.0593-0.1421), and the variability is similar to that observed in the whole rocks measured from Malumalu seamount. The $\mathrm{Rb} / \mathrm{Sr}$ ratios in OFU-04-06 melt inclusions show some heterogeneity $(\mathrm{Rb} / \mathrm{Sr}$ from 0.0476 to $0.0595, n=7)$, but this variability is smaller than the variability sampled by whole-rock lavas from the island. Vailulu'u melt inclusions from dredge samples 71-2 ( Rb/Sr from 0.0469 to $0.1028, n=12$ melt inclusions) and $68-3(\mathrm{Rb} / \mathrm{Sr}$ from 0.060 to $0.1027, n=3$ ) exhibit a range of $\mathrm{Rb} / \mathrm{Sr}$ values that falls between 78-1 and OFU-04-06. Unlike the isotopes, however, the magnitude of the $\mathrm{Rb} / \mathrm{Sr}$ heterogeneity in the melt inclusions from samples 71-2 and 68-3 is greater than the variability observed in Vailulu'u seamount lavas, and, within error of measurement, do not sample a component with lower $\mathrm{Rb} / \mathrm{Sr}$ than observed in whole rocks from this seamount.

The present dataset suggests that the isotopic variability exhibited by the melt inclusions in a basalt sample may be a function of the whole-rock isotopic composition. In Fig. 2, the Sr-isotope variability of melt inclusions in three basalt samples-those with the largest number of melt inclusion analyses-is plotted against the bulk ${ }^{87} \mathrm{Sr} /{ }^{86} \mathrm{Sr}$ composition of the respective whole rocks. The ${ }^{87} \mathrm{Sr} /{ }^{86} \mathrm{Sr}$ variability, determined by the difference between the highest and the lowest ${ }^{87} \mathrm{Sr} /{ }^{86} \mathrm{Sr}$
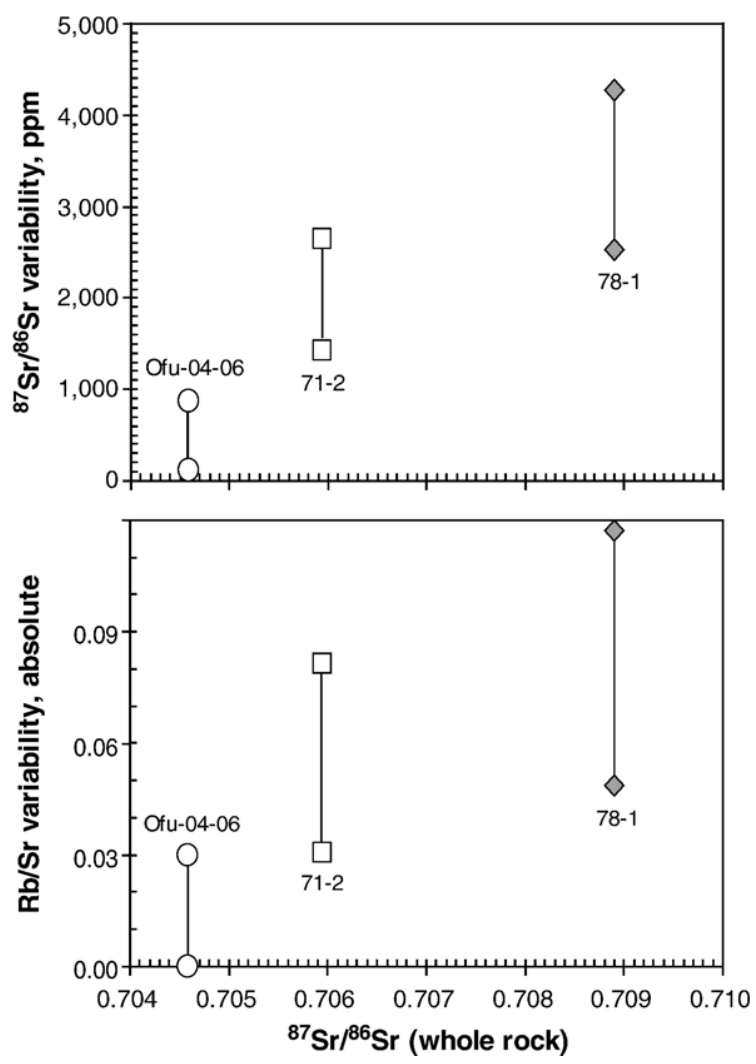

Fig. 2. Upper panel: Melt inclusion isotopic variability (in ppm) as a function of whole-rock ${ }^{87} \mathrm{Sr} /{ }^{86} \mathrm{Sr}$ ratio for the three Samoan lavas with the greatest number of melt inclusion analyses. Melt inclusion isotopic variability increases with increasing ${ }^{87} \mathrm{Sr} /{ }^{86} \mathrm{Sr}$ (and decreasing ${ }^{3} \mathrm{He} /$ ${ }^{4} \mathrm{He}$, not shown) in the three Samoan basalts. Variability is determined by the difference between the most isotopically extreme melt inclusions in a basalt sample. The maximum and minimum values for this variability are a result of the uncertainty introduced by the $\mathrm{Rb}$ correction, which is directly related to the $\mathrm{Rb} / \mathrm{Sr}$ of the melt inclusion. For example, the maximum variability in basalt sample $78-1$ is determined by the difference between the highest $(0.7092$ plus $391 \mathrm{ppm}$ uncertainty) and lowest plausible ${ }^{87} \mathrm{Sr} /{ }^{86} \mathrm{Sr}$ (0.7072 minus $393 \mathrm{ppm}$ uncertainty). The minimum variability is determined by the difference between the lowest plausible ${ }^{87} \mathrm{Sr} /{ }^{86} \mathrm{Sr}$ in the most enriched melt inclusion (i.e., 0.7089 , or 0.7092 minus 389 ppm uncertainty) and the highest plausible ${ }^{87} \mathrm{Sr} /{ }^{86} \mathrm{Sr}$ in the most depleted melt inclusion (0.7074, or 0.7072 plus 393 ppm uncertainty). Lower panel: Melt inclusion $\mathrm{Rb} / \mathrm{Sr}$ variability (absolute) as a function of whole-rock ${ }^{87} \mathrm{Sr} /$

${ }^{86} \mathrm{Sr}$ ratio. Maximum and minimum variability is determined the same way, but assumes an uncertainty for $\mathrm{Rb} / \mathrm{Sr}$ of $17 \%$. The magnitude of variability due to internal precision is approximated by the size of the data symbols in both panels. 
ratios from melt inclusions in a given basalt sample, exhibits a maximum and a minimum due to the uncertainty introduced by the $\mathrm{Rb}$ correction. Although the number of data points is limited, the data are consistent with melt inclusion isotopic diversity increasing with increasing ${ }^{87} \mathrm{Sr} /{ }^{86} \mathrm{Sr}$ (increasing EM2 component) and decreasing ${ }^{3} \mathrm{He} /{ }^{4} \mathrm{He}$ (not shown). The range of variability for Malumalu sample 78-1 is larger than, but overlaps with, the range of values from Vailulu'u sample 71-2. The melt inclusions from the high ${ }^{3} \mathrm{He} /{ }^{4} \mathrm{He}$ Ofu basalt exhibit the smallest range of probable ${ }^{87} \mathrm{Sr} /$ ${ }^{86} \mathrm{Sr}$ ratios, and they do not overlap with the range from samples 71-2 and 78-1. A similar observation can be made for the variability of $\mathrm{Rb} / \mathrm{Sr}$ ratios in the melt inclusions, where $\mathrm{Rb} / \mathrm{Sr}$ tends toward greater melt inclusion variability in samples 78-1 and 71-2; the Ofu sample has the smallest range of variability, and overlaps slightly with the lowest probable variability in sample 71-2. It is notable that OFU-04-06 exhibits the highest ${ }^{3} \mathrm{He} /{ }^{4} \mathrm{He}$ ratio (and low ${ }^{87} \mathrm{Sr} /{ }^{86} \mathrm{Sr}$ ) found in Samoa, an observation that may be linked to the small degree of isotopic and trace element variability in its melt inclusions.

\subsection{Major and trace element characteristics of melt inclusions}

$\mathrm{Rb} / \mathrm{Sr}$ and ${ }^{87} \mathrm{Sr} /{ }^{86} \mathrm{Sr}$ ratios from the melt inclusions define a broad array that encompasses the entire spectrum of $\mathrm{Sr}$-isotope and $\mathrm{Rb} / \mathrm{Sr}$ variability recorded in Samoan basalts (Fig. 3). Curiously, the melt inclusions from Malumalu do not form an array by themselves, but plot over a broad region. $\mathrm{The} \mathrm{Rb} / \mathrm{Sr}$ and $\mathrm{Sr}$-isotope data array form a crude mantle isochron of $1.1 \mathrm{Ga}$.

Major and trace elements were measured on melt inclusions from Vailulu'u, Malumalu and Ofu basalts, and they reveal a large range of compositions (Table 2). Although the trace element compositions of Vailulu'u melt inclusions are similar to whole-rock analyses from this seamount, melt inclusions from EM2 endmember basalt 78-1 record a greater degree of trace element variability than all of the whole rocks measured from Malumalu. One

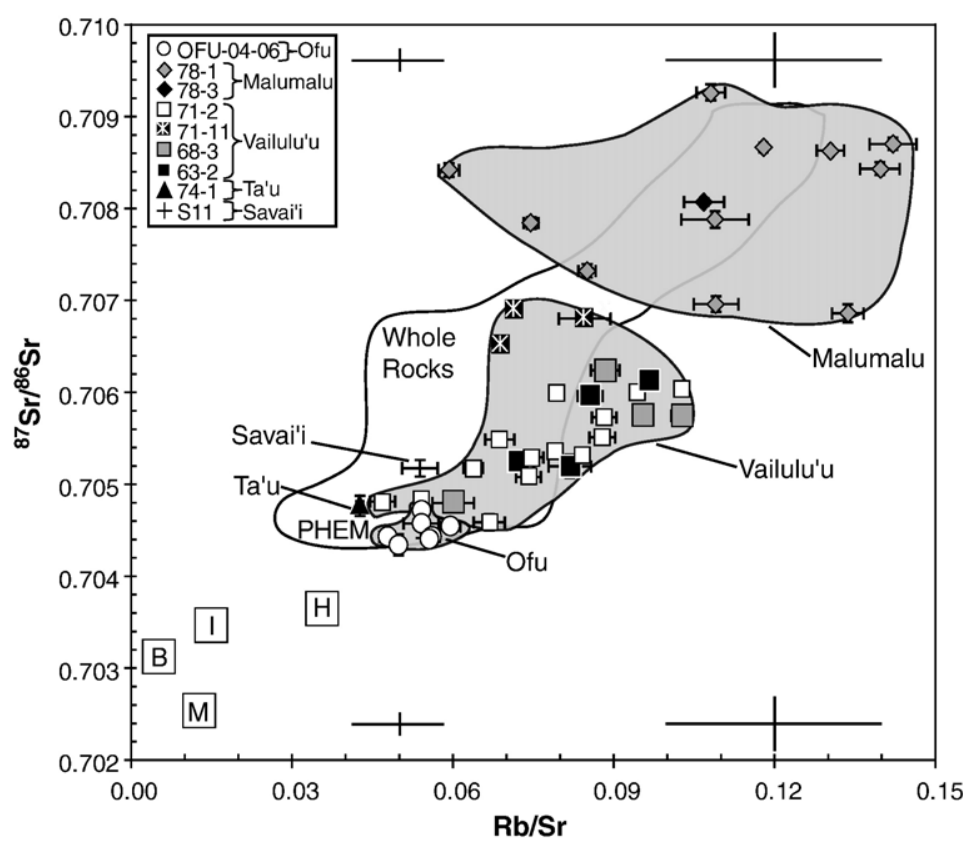

Fig. $3{ }^{87} \mathrm{Sr} /{ }^{86} \mathrm{Sr}$ versus $\mathrm{Rb} / \mathrm{Sr}$ ratios for Samoan whole rocks and melt inclusions, determined by laser ablation. The shaded regions represent the extent of melt inclusion variability for the volcanoes (Vailulu'u, Malumalu and Ofu). The open region encompasses the least evolved $(\mathrm{MgO} \geq 6.5$ wt.\%) whole-rock measurements from these three volcanoes and Ta'u, thus encompassing islands and seamounts only on the eastern half of the Samoan hotspot track (where $\sim 98 \%$ of the analyzed melt inclusions were recovered). Whole-rock data from Ofu is unpublished, and for the other volcanoes is from [4]. MORB range is limited to EPR N-MORB (M) segment averages [22]. High ${ }^{3} \mathrm{He} /{ }^{4} \mathrm{He}$ basalts from Hawaii (H) [37], Iceland (I) [38] and Baffin Island (B) [39] provide an approximation for FOZO (higher ${ }^{3} \mathrm{He} /{ }^{4} \mathrm{He}$ ratios exist for Hawaiian basalts [40], but ${ }^{87} \mathrm{Sr} /{ }^{86} \mathrm{Sr}$ data are not available for these samples; $\mathrm{Rb} / \mathrm{Sr}$ data for high ${ }^{3} \mathrm{He} /{ }^{4} \mathrm{He}$ samples from Baffin Island are found in [41]). Error bars on symbols are internal precision of measurement ( $2 \sigma$, mean deviation). Error bars on periphery of figure denote external precision of measurements, as determined by Samoan glass standards with compositions similar to the melt inclusions: $\mathrm{Rb} / \mathrm{Sr}$ error is $17 \%\left(2 \sigma\right.$, standard deviation) and ${ }^{87} \mathrm{Sr} /$ ${ }^{86} \mathrm{Sr}$ error is based on error associated with the $\mathrm{Rb}$ correction $(2 \sigma$, standard deviation). Replicate analyses of the same melt inclusion are shown. The melt inclusion data form a crude mantle isochron age of $\sim 1.1 \mathrm{Ga}$. 
Table 2

Melt inclusion major and trace element data (uncorrected for olivine fractionation), and host olivine composition

\begin{tabular}{|c|c|c|c|c|c|c|c|c|c|c|c|c|c|c|c|c|c|c|c|c|c|c|c|c|}
\hline Sample \# & Disc \# & Grain \# & $\neq \mathrm{SiO}_{2}$ & $\mathrm{TiO}_{2}$ & $\mathrm{Al}_{2} \mathrm{O}_{3}$ & $\mathrm{FeO}$ & $\mathrm{MnO}$ & $\mathrm{MgO}$ & $\mathrm{CaO}$ & $\mathrm{Na}_{2} \mathrm{O}$ & $\mathrm{K}_{2} \mathrm{O}$ & $\mathrm{P}_{2} \mathrm{O}_{5}$ & Total & $\mathrm{Mg} \#$ & OlFo & & $\mathrm{Sr}$ & $\mathrm{Y}$ & $\mathrm{Zr}$ & $\mathrm{Nb}$ & $\mathrm{Ba}$ & $\mathrm{La}$ & $\mathrm{Sr} /$ & Type \\
\hline $3-1$ & Disc1 & $\# 7$ & 45.64 & 77 & 12.97 & 14.11 & 7 & 0.03 & 9.53 & 3.46 & 6 & 0 & 99.19 & 47.0 & 84.6 & 181 & 1176 & 3.6 & 979 & 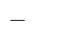 & - & 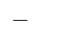 & (.) & - \\
\hline-1 & Disc1 & $\# 9$ & 46.57 & 99 & 13.06 & .75 & & 02 & 13.09 & 2.94 & & & 99.74 & & 84.4 & 49 & 443 & & 245 & - & - & 45.6 & & $\mathrm{H}$ \\
\hline-1 & Disc1 & $\# 10-11$ & 44.98 & .22 & 12.84 & .18 & 0.14 & .26 & 11.29 & 2.62 & 76 & 39 & 98.10 & 62.1 & 84.0 & 75 & 507 & 8.1 & 269 & - & - & - & - & $\mathrm{H}$ \\
\hline 78-1 & Disc1 & $\# 12$ & 46.37 & 3.76 & 13.09 & 11.51 & 0.17 & 8.03 & 11.38 & 2.93 & 1.91 & 0.40 & 99.65 & 58.0 & 84.4 & 59 & 545 & 3.2 & 339 & 73.1 & 390 & - & - & $\mathrm{H}$ \\
\hline 78-1 & Disc2 & $\# 5$ & 45.16 & 3.42 & 12.62 & 11.09 & 0.17 & 9.15 & 12.42 & 2.46 & 1.42 & 0.42 & 98.68 & 62.0 & 84.3 & 130 & 1127 & 75.5 & 568 & 132.9 & 796 & 96.1 & - & $\mathrm{H}$ \\
\hline $3-1$ & Disc2 & $\# 6$ & 47.22 & 3.45 & 13.60 & 11.80 & 0.23 & 7.10 & 10.17 & 3.13 & 2.10 & 0.42 & 99.38 & 54.4 & 83.6 & 115 & 926 & 54.1 & 543 & 122.4 & 666 & 93.8 & 0.7 & $\mathrm{H}$ \\
\hline $8-1$ & Disc2 & $\# 7$ & 47.20 & 2.92 & 13.65 & 9.94 & 0.14 & 7.83 & 11.36 & 2.73 & 2.00 & 0.40 & & 60.9 & 83.9 & - & - & - & - & - & - & - & - & $\mathrm{H}$ \\
\hline-1 & Disc2 & $\# 8$ & 45.57 & 3.20 & 12.26 & 11.20 & 0.17 & 9.26 & 11.33 & 2.71 & 1.33 & 0 & 97.88 & 62.1 & 83.6 & 71 & 679 & 40.6 & 360 & 76.0 & 409 & 57.7 & - & $\mathrm{H}$ \\
\hline-1 & Disc2 & $\# 9$ & 46.81 & 3.46 & 14.03 & 11.81 & 0.16 & 7.34 & 10.54 & 2.93 & 1.91 & 3 & 99.59 & 55.2 & 82.8 & 76 & 655 & 38.7 & 400 & 8 & 482 & 2.3 & 0.70 & $\mathrm{H}$ \\
\hline-1 & Disc2 & $\# 10$ & 46.32 & .46 & 13.16 & 11.01 & 0.15 & 7.65 & 11.60 & 4.80 & 1.27 & 0.46 & 100.01 & 57.9 & 83.6 & 33 & 631 & 37.3 & 346 & 73.4 & 450 & 55.1 & & $\mathrm{H}$ \\
\hline $3-1$ & Disc2 & $\# 11 \mathrm{Le}$ & 46.32 & 3.24 & 12.74 & 11.04 & 0.14 & 8.18 & 12.72 & 3.18 & 1.33 & 0.39 & 99.67 & 59.5 & 83.6 & 55 & 598 & 36.7 & 281 & 56.1 & 401 & 45.5 & - & $\mathrm{H}$ \\
\hline $8-1$ & Disc2 & $\# 11$ RtS & - & - & - & - & - & - & - & - & - & - & - & - & 83.2 & 194 & 1694 & 100.5 & 871 & 193.5 & 1258 & 173.6 & - & $\mathrm{H}$ \\
\hline $8-1$ & Disc2 & $\# 11$ RtL & 44.61 & 3.77 & 12.99 & 11.76 & 0.19 & 6.23 & 13.20 & 2.70 & 1.57 & 0.44 & 97.85 & 51.2 & 83.2 & 299 & 2480 & 158.7 & 1310 & 293.5 & 1887 & 246.6 & - & $\mathrm{H}$ \\
\hline 78-1 & Disc2 & $\# 3$ & 46.09 & 3.23 & 12.50 & 10.68 & 0.1 & 8.85 & 11.47 & 2.5 & 1.59 & 0. & & 62.1 & 84.1 & 135 & 1038 & 62.5 & 579 & & 719 & 0.6 & - & $\mathrm{H}$ \\
\hline-1 & Disc2 & \# & 46.45 & 2.99 & 12.17 & 10.32 & 0 & 9.22 & 12.92 & 2.3 & 1.37 & & 98.80 & 63.9 & 3.9 & 104 & 901 & 55.1 & 5 & & 36 & 8.9 & - & $\mathrm{H}$ \\
\hline-1 & Disc3 & $\# 4$ & 46.07 & 3.81 & 13.22 & 10.47 & 0.12 & 6.00 & 12.52 & 2.93 & 1.80 & 0.42 & 97.81 & 53.1 & 85.2 & 69 & 555 & 26.4 & 297 & & 370 & 55.4 & 0.7 & $\mathrm{G}$ \\
\hline-2 & Disc1 & $\mathrm{g} \# 3-4$ & 48.50 & 2.66 & 12.55 & 9.41 & 0.14 & 7.38 & 14.63 & 2.33 & 0.84 & 03 & 99.13 & 60.8 & 87.4 & 26 & 384 & 23.0 & 185 & 30.4 & 124 & 22.4 & - & $\mathrm{G}$ \\
\hline $1-2$ & Disc1 & $\mathrm{i}$ & 48.13 & 2.57 & 12.54 & 9.21 & 0.14 & 8.07 & 13.85 & 2.48 & 0.78 & 0.27 & 98.40 & 63.4 & 90.7 & - & - & - & - & - & - & - & 0.7 & G \\
\hline $1-2$ & Disc3 & $\# 3$ & 46.12 & 3.48 & 13.06 & 10.94 & 0.15 & 5.81 & 14.09 & 2.55 & 1.29 & 0.3 & 98.23 & 51.3 & 84.3 & 50 & 517 & 29.5 & 237 & 52.7 & 347 & 40.9 & - & G \\
\hline $71-2$ & Disc3 & $\# 5$ & 46.71 & 3.10 & 12.72 & 9.66 & 0.15 & 7.90 & 13.10 & 2.45 & 1.24 & 0.3 & 97.72 & 61.8 & 91.0 & 45 & 504 & 27.1 & 243 & 58.8 & 314 & 35.3 & 0.7 & $\mathrm{G}$ \\
\hline $71-2$ & Disc3 & $\# 6$ & 46.46 & 3.23 & 12.31 & 10.52 & 0.1 & 7.54 & 13.64 & 2.6 & 1.14 & & & 58.7 & 85.7 & 50 & 5 & 33.3 & & & 20 & 9 & & $G$ \\
\hline 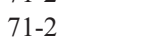 & $\mathrm{J}$ & $\mathrm{C}$ & & $J$ & & & & & 1 & & & & & & & 27 & & & & & 177 & 9 & & $G$ \\
\hline-11 & Disc3 & $\# 1$ & 49.01 & 3.13 & 12.53 & 11.05 & 0.18 & 6.15 & 12.01 & 2.85 & 0.94 & 0.40 & 98.51 & 52.4 & 81.4 & 34 & 419 & 27.1 & 232 & 41.4 & 205 & 35.6 & 0.7 & G \\
\hline $71-11$ & Disc1 & $\mathrm{a}$ & 49.28 & 2.82 & 12.70 & 10.94 & 0.14 & 6.89 & 11.63 & 2.60 & 1.01 & 0.37 & 98.73 & 55.5 & 83.0 & 36 & 409 & 30.3 & 223 & 40.9 & 214 & 33.0 & & G \\
\hline $68-3$ & Disc1 & $\# 6 \mathrm{mil}$ & 48.77 & 2.88 & 14.30 & 8.75 & 0.13 & 4.68 & 14.74 & 2.64 & 1.35 & 0.37 & 98.98 & 51.4 & 87.9 & 54 & 533 & 27.0 & 260 & 62.5 & 378 & 46.3 & 0.7 & G \\
\hline OFU-04-06 & Ofu & 13 & 44.25 & 3.31 & 12.60 & 10.10 & 0.11 & 7.99 & 13.38 & 3.40 & 0.94 & 0.50 & 96.75 & 61.4 & 79.8 & 52 & 856 & 41.6 & 464 & 76.8 & 343 & 106.2 & $0.7 c$ & $\mathrm{H}$ \\
\hline FU- & Ofu & 14 & 46.33 & 3 & 14.03 & 8 & 0. & 8. & 11.89 & 3. & 1.08 & & & 54.9 & 80.4 & 61 & 6 & 33.3 & 3 & 5 & 311 & 77.8 & - & $\mathrm{H}$ \\
\hline 06 & Ofu & 15 & 46 & 2.81 & 13 & 10.58 & 0 . & 7.20 & 10 & & 1.09 & & & 60.5 & & 60 & 0 & 0 & 374 & & 3 & 2.1 & & $\mathrm{H}$ \\
\hline PFU-04-06 & Ofu & 16 & 46.74 & 3.13 & 14.12 & 7.00 & 0.09 & 8.26 & 13.11 & 3.76 & 1.19 & $0 .{ }^{2}+2$ & & 49.5 & 01.9 & 68 & 760 & 38.6 & 393 & 72.5 & 363 & 91.1 & - & $\mathrm{H}$ \\
\hline OFU-04-06 & Ofu & 18 & 50.44 & 1.16 & 14.17 & 7.56 & 0.07 & 7.33 & 11.22 & 4.69 & 1.38 & 0.39 & 98.67 & 51.4 & 79.3 & 63 & 926 & 33.8 & 460 & 84.1 & 399 & 113.9 & - & $\mathrm{H}$ \\
\hline OFU-04-06 & Ofu & 19 & 47.15 & 2.14 & 11.15 & 17.06 & 0.21 & 13.83 & 2.72 & 1.56 & 1.71 & 0.46 & 98.00 & 75.2 & 76.6 & - & - & - & - & - & - & - & - & $\mathrm{H}$ \\
\hline OFU-04-06 & Ofu & 20 & 47.36 & 2.90 & 14.50 & 9.00 & 0.13 & 7.59 & 10.84 & 4.02 & 1.06 & 0.39 & 97.84 & 55.1 & 78.6 & 81 & 909 & 39.0 & 438 & 70.3 & 402 & 32.5 & - & $\mathrm{H}$ \\
\hline OFU-04-06 & Ofu & $24 \mathrm{re}$ & 46.35 & 3.58 & 13.47 & 8.58 & 0.09 & 8.11 & 13.70 & 3.23 & 0.72 & 0.29 & 98.13 & 55.8 & 83.0 & - & - & - & - & - & - & - & - & $\mathrm{H}$ \\
\hline OFU-04-06 & Ofu & 25 & 45.74 & 3.16 & 13.55 & & 0.1 & 7.71 & & 3. & 0.89 & & & 63.6 & 77.2 & 59 & 659 & 38.1 & 383 & 48.7 & 243 & - & & $\mathrm{H}$ \\
\hline OFU-04-06 & Ofu & 26 & 46.14 & 2.51 & 12.70 & 10.60 & 0.10 & 8.04 & 13.61 & 3.01 & 0.74 & 0.34 & 97.93 & 62.3 & 76.5 & 45 & 573 & 37.7 & 338 & 42.3 & 191 & - & 0.70443 & $\mathrm{H}$ \\
\hline
\end{tabular}




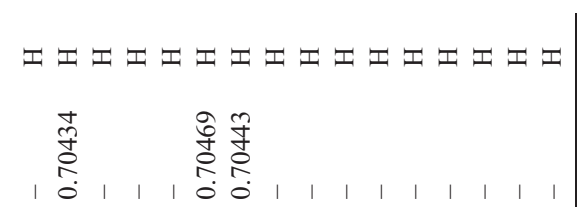

t.

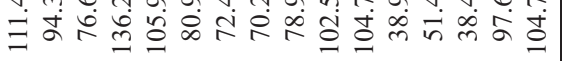

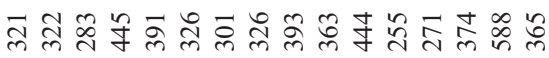

$\infty$ -

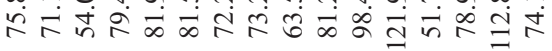

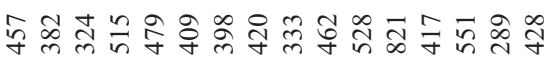

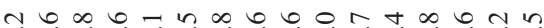

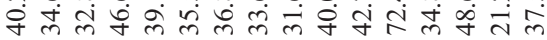

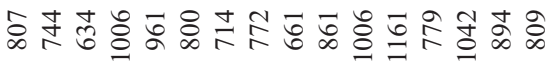

路

nt.

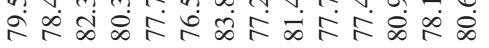

Oํ

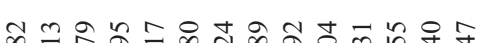

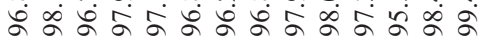

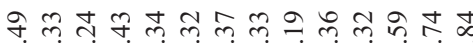

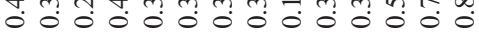

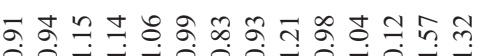

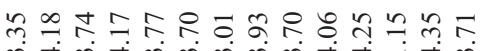

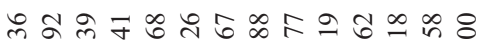

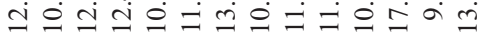

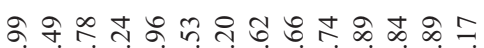

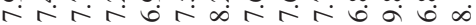

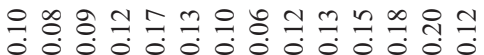

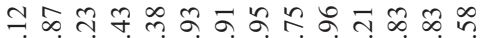

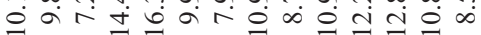

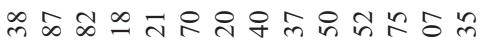

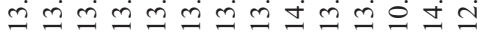

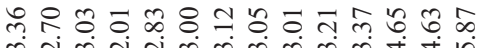

लतल तथलmलm m

징 ส

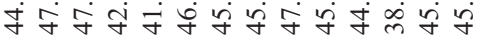

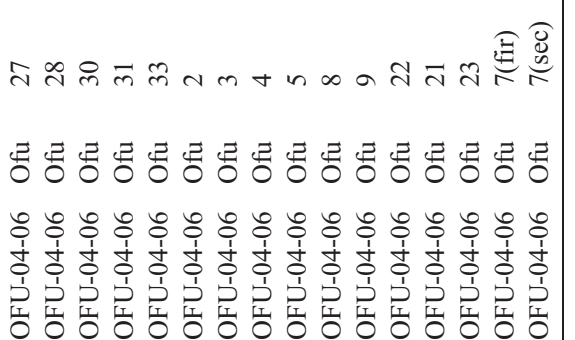

melt inclusion from sample 78-1 displays high $\mathrm{Sr}$ and $\mathrm{Ba}$ concentrations ( 2500 and $1900 \mathrm{ppm}$, respectively) that are 6 times more enriched than any whole-rock lavas examined from Malumalu. This ultra-enriched composition is significantly more enriched than observed in any Samoan basalts, and is derived from either an extremely enriched source or from very small degrees of melting.

Melt inclusions from OFU-04-06 also exhibit some unusual major and trace element compositions. One $\mathrm{Ofu}$ melt inclusion exhibits unusually low $\mathrm{K}_{2} \mathrm{O}$ concentrations. Additionally, the OFU-04-06 melt inclusions exhibit a large range in $\mathrm{SiO}_{2}$, including one sample with unusually low $\mathrm{SiO}_{2}(38.0 \%)$ and high $\mathrm{CaO}$ (17.2\%). These uncommon major element compositions may be due to the combination of unusual phases present in the OFU-04-06 melt inclusions prior to homogenization in the lab. Low glass totals in the OFU-04-06 inclusions are likely due to high volatile contents in the homogenized glasses, a hypothesis consistent with the volatile-rich phases in melt inclusions from this sample.

In addition to $\mathrm{Rb} / \mathrm{Sr}$ ratios, several other major and trace element parameters correlate with ${ }^{87} \mathrm{Sr} /{ }^{86} \mathrm{Sr}$ in the melt inclusions. Melt inclusions from Ofu, Vailulu'u and Malumalu exhibit negative $\mathrm{Ba}$ anomalies that also are observed in Samoan shield-stage lavas [4] (Fig. 4). An approximation for this $\mathrm{Ba}$ anomaly is $(\mathrm{Ba} / \mathrm{Nb})_{\mathrm{N}}$ (normalized to PUM, primitive upper mantle [30]), a ratio which correlates with ${ }^{87} \mathrm{Sr} /{ }^{86} \mathrm{Sr}$ in whole rocks and melt inclusions (Fig. 5). The $(\mathrm{Ba} / \mathrm{Nb})_{\mathrm{N}}$ values are lowest (largest Ba-anomaly) in the basalts and melt inclusions with low ${ }^{87} \mathrm{Sr} /{ }^{86} \mathrm{Sr}$, and highest in the basalts and melt inclusions with elevated ${ }^{87} \mathrm{Sr} /{ }^{86} \mathrm{Sr}$ ratios. It is notable that basalts and melt inclusions associated with elevated ${ }^{3} \mathrm{He} /{ }^{4} \mathrm{He}$ ratios, and not the high ${ }^{87} \mathrm{Sr} /{ }^{86} \mathrm{Sr} \mathrm{EM} 2$ endmember basalts, have the largest $\mathrm{Ba}$ anomalies. The mechanism that generates this anomaly is unknown [4], and the anomaly also exists in MORB and HIMU basalts, but not in basalts with EM1 characteristics.

The negative $\mathrm{K}_{2} \mathrm{O}$ anomaly in the Samoan melt inclusions (Fig. 4) is commonly observed in OIBs. Curiously, however, PUM-normalized K exhibits little variability regardless of the degree of enrichment of the other trace elements (with the exception of a single Ofu melt inclusion). Despite the limited variability, olivine fractionation-corrected $\mathrm{K}_{2} \mathrm{O}$ concentrations exhibit a relationship with ${ }^{87} \mathrm{Sr} /{ }^{86} \mathrm{Sr}$ in the melt inclusions (Fig. 5).

$\mathrm{Nb} / \mathrm{Zr}$ also correlates with ${ }^{87} \mathrm{Sr} /{ }^{86} \mathrm{Sr}$ in Samoan basalts and melt inclusions (Fig. 5). The lowest $\mathrm{Nb} / \mathrm{Zr}$ ratios are associated with unradiogenic ${ }^{87} \mathrm{Sr} /{ }^{86} \mathrm{Sr}$ values. $\mathrm{Nb} / \mathrm{Zr}$ ratios correlate with $\mathrm{Pb}$-isotopes [4] and inversely with ${ }^{3} \mathrm{He} /$ 


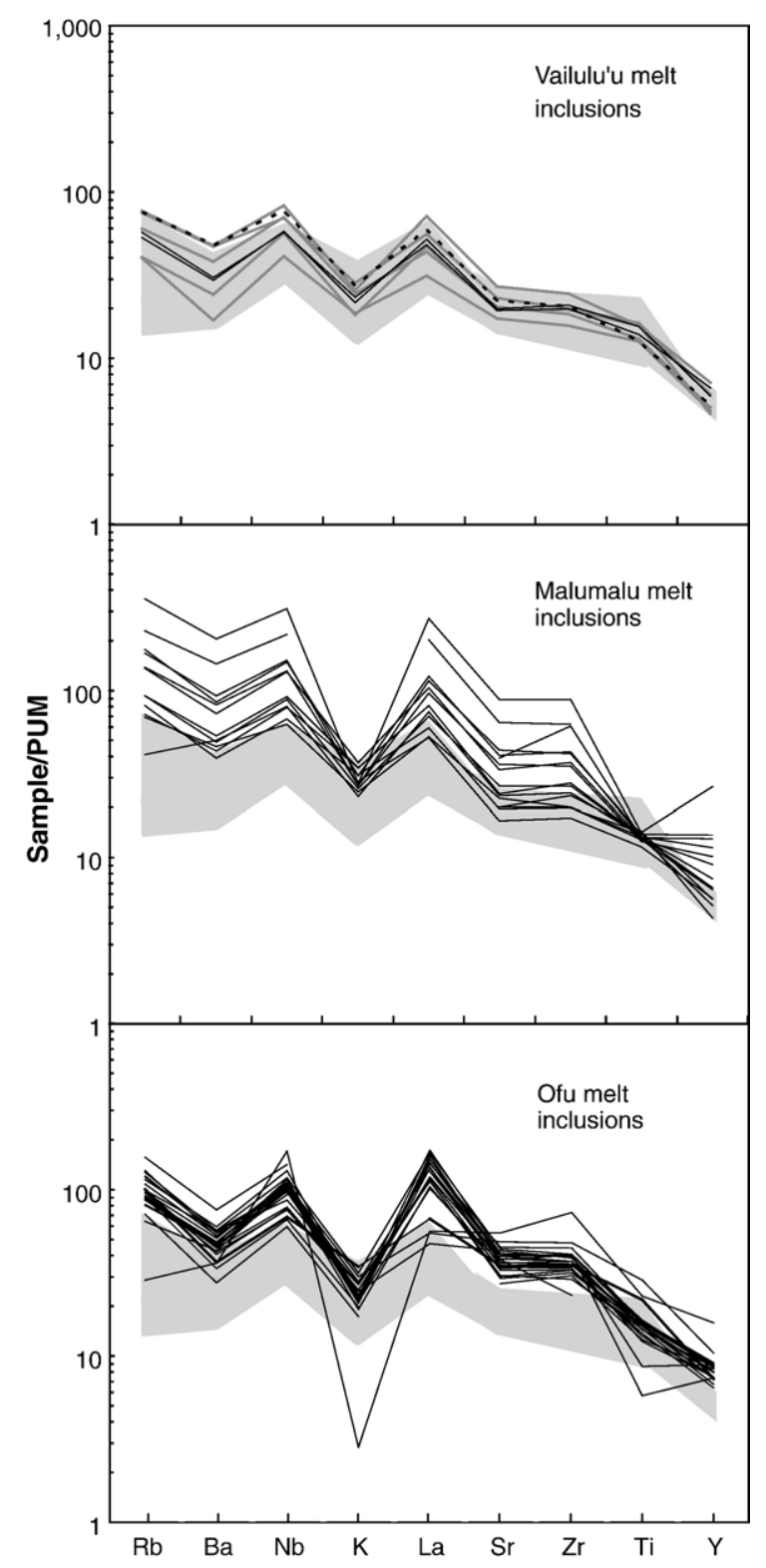

Fig. 4. PUM-normalized trace element patterns of Samoan basalts and melt inclusions; melt inclusion data is from ion probe analysis, except for $\mathrm{K}$ and $\mathrm{Ti}$, which were measured by electron probe. Vailulu'u melt inclusions are from three samples: 71-2 (grey lines), 68-3 (dashed line), 71-11 (solid black lines). Malumalu and Ofu melt inclusions are from samples 78-1 and OFU-04-06, respectively. All melt inclusions (except for one melt inclusion from 78-1 and two from OFU-04-06 that have no major element compositions, see Table 2) are corrected for olivine fractionation to be in equilibrium with mantle olivine of $\mathrm{Fo}_{90}$ (see text for correction scheme). The grey field encloses the range of whole-rock patterns from the least evolved basalts $(>6.5 \mathrm{wt} \% \mathrm{MgO})$ from Vailulu'u, Ofu and Malumalu; whole-rock compositions have been corrected for olivine addition/fractionation. PUM values from [30].
${ }^{4} \mathrm{He}$ (not shown) in Samoan basalts. $\mathrm{Nb} / \mathrm{Zr}$ may serve as a proxy for ${ }^{3} \mathrm{He} /{ }^{4} \mathrm{He}$ isotopes in Samoan melt inclusions; therefore, it may be important that the $\mathrm{Nb} / \mathrm{Zr}$ ratios in several of the Ofu-04-06 melt inclusions exhibit values lower than the ratios observed in whole rocks.

\subsection{Melting models of the EM2 source}

It is important to place constraints on the trace element variability introduced by melting processes. A plot of $\mathrm{Sr}$ versus $\mathrm{Ti} / \mathrm{Zr}$ shows that the majority of the melt inclusions form an array that extends outside of the whole-rock field to enriched $\mathrm{Sr}$ and low $\mathrm{Ti} / \mathrm{Zr}$ values (Fig. 6). The low Ti/Zr ratios (15-88) observed in the melt inclusions extend to lower values than observed in whole-rock basalts from the eastern Samoa islands and seamounts (63-130). Such low values cannot be produced by crystal fractionation of melts before olivine entrapment, and assimilation of MORB $(\mathrm{Ti} / \mathrm{Zr}=88)$ also fails to produce low $\mathrm{Ti} / \mathrm{Zr}$ values [31]. A model of the Samoan EM2 source composition [4] provides a robust estimate for the mantle source sampled by the extreme EM2 basalt sample 78-1, and variable degrees of aggregated modal fractional melts of this source $(\mathrm{Sr}=20.0 \mathrm{ppm}, \mathrm{Ti} / \mathrm{Zr}=101.9)$ in the garnet and spinel stability fields can describe much of the melt inclusion array in Fig. 6. Consistent with the model of the EM2 source as a metasomatized harzburgite [4], we adopt a harzburgite source lithology (1\% spinel, 3.6\% clinopyroxene [cpx], 20.6\% orthopyroxene [opx] and 74.8\% olivine), with mineral modes from [32] and mineral $/$ melt partition coefficients from [33]. We assume the mineral modes of a similar bulk composition for melting in the garnet stability field (3.8\% garnet, $2.7 \% \mathrm{cpx}, 17.7 \% \mathrm{opx}$ and $75.8 \%$ olivine) using the spinel to garnet conversion from [34]. The two melting models follow similar trajectories, but melting in the spinel stability field is required to generate the exceptionally high $\mathrm{Sr}$ and low $\mathrm{Ti} / \mathrm{Zr}$ observed in the ultra-enriched Malumalu melt inclusions. Interestingly, if the EM2 source [4] has a more cpx-rich lithology than the harzburgite in our melting model, it will not produce melts with the $\mathrm{Sr}$ concentrations observed in the most enriched melt inclusion at reasonable degrees ( $>1 \%$ ) of melting (Fig. 7).

Other geochemical indicators, including $\mathrm{Y} / \mathrm{Zr}$ ratios, more clearly resolve the relative roles of melting in the garnet and spinel stability fields. Due to the relative compatibility of $\mathrm{Y}$ in residual garnet, low $\mathrm{Y} / \mathrm{Zr}$ ratios are consistent with melting in the presence of garnet. A role for melting in the garnet stability field is suggested in a plot of $\mathrm{Y} / \mathrm{Zr}$ against $\mathrm{Nb} / \mathrm{Zr}$ in Fig. 6. This is particularly true for the Ofu melt inclusions, which trend to the lowest $\mathrm{Y} / \mathrm{Zr}$ ratios 

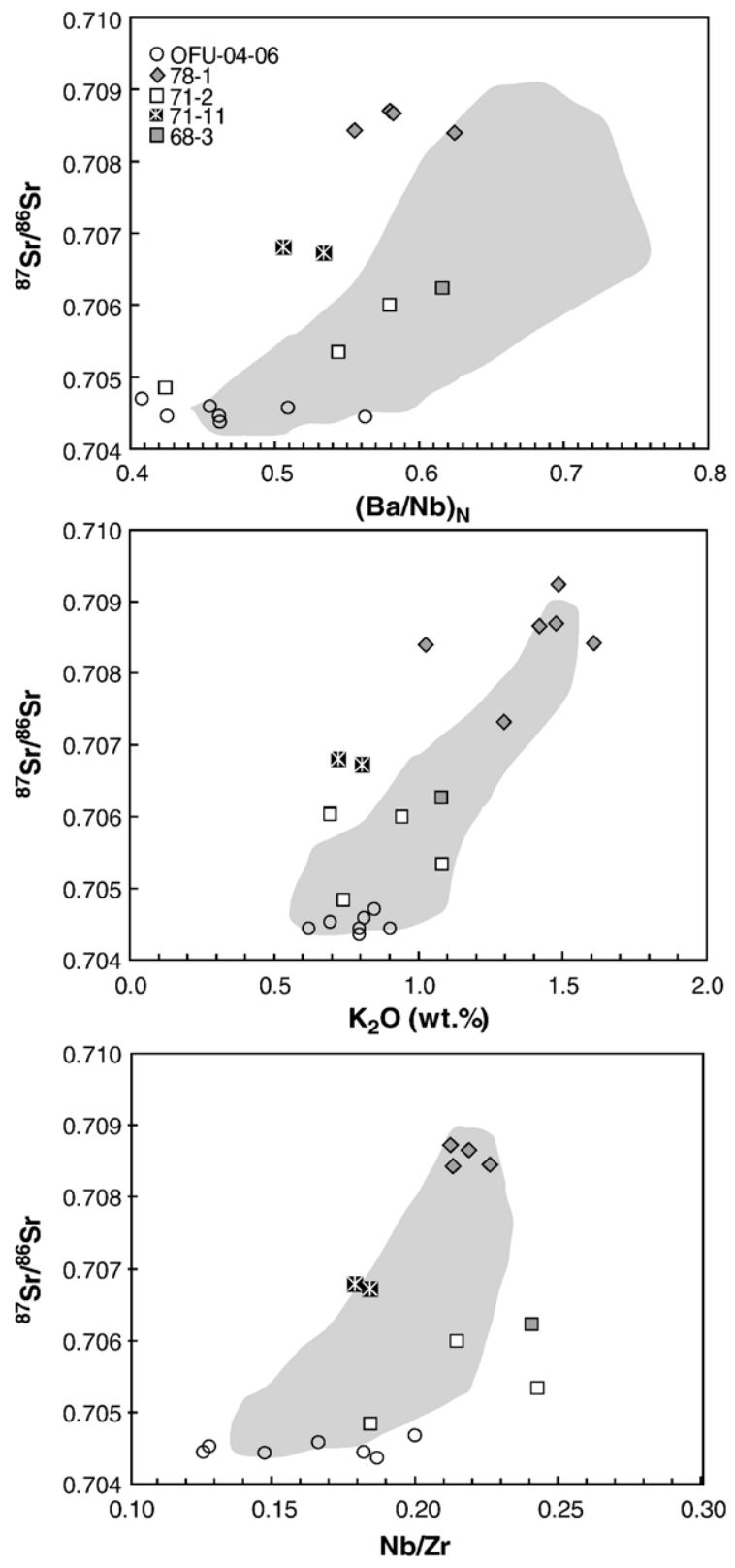

Fig. 5. $\mathrm{Nb} / \mathrm{Zr}, \mathrm{K}_{2} \mathrm{O}$ and $\mathrm{Ba} / \mathrm{Nb}_{\mathrm{N}}$ versus ${ }^{87} \mathrm{Sr} /{ }^{86} \mathrm{Sr}$. $\mathrm{K}_{2} \mathrm{O}$ measured by electron probe, and $\mathrm{Nb}, \mathrm{Zr}$ and $\mathrm{Ba}$ by ion probe. $(\mathrm{Ba} / \mathrm{Nb})_{\mathrm{N}}$ (normalized to PUM) is used as a proxy for the pervasive negative Ba anomaly in Samoan shield-stage basalts. The EM2 basalts and melt inclusions are associated with elevated $\mathrm{Nb} / \mathrm{Zr}, \mathrm{K}_{2} \mathrm{O}$ and $(\mathrm{Ba} / \mathrm{Nb})_{\mathrm{N}}$ (smaller negative $\mathrm{Ba}$ anomalies), and the low ${ }^{87} \mathrm{Sr} /{ }^{86} \mathrm{Sr}$ basalts exhibit lower $\mathrm{Nb} / \mathrm{Zr}, \mathrm{K}_{2} \mathrm{O}$ and $(\mathrm{Ba} / \mathrm{Nb})_{\mathrm{N}}$ (larger negative $\mathrm{Ba}$ anomalies). All melt inclusions are corrected for olivine fractionation. The grey fields enclose the range of whole-rock patterns from the least evolved basalts $(>6.5 \mathrm{wt} . \% \mathrm{MgO})$ from Vailulu'u, Ofu and Malumalu (whole-rock compositions have been corrected for olivine addition/fractionation). Symbols are the same as Fig. $3 .{ }^{87} \mathrm{Sr} /{ }^{86} \mathrm{Sr}$ internal precision $(2 \sigma$, standard error $)$ is approximately the size of the symbol. observed in the melt inclusions suite and straddle the garnet melting trend at $5 \%$ melt. This is similar to the $\mathrm{Ti} / \mathrm{Zr}$ versus Sr plot, where the garnet melting curve trends through the Ofu melt inclusion field at $\sim 4 \%$ melt. Malumalu and Vailulu'u melt inclusions (and Samoan whole rocks) are offset to higher $\mathrm{Y} / \mathrm{Zr}$ ratios, perhaps suggesting a larger role for melting in the spinel stability field, an observation that is consistent with the same subset of melt inclusions in the Ti/ $\mathrm{Zr}$ versus Sr melt model.

No single melting model of the EM2 source perfectly describes the melt inclusion fields for all three volcanoes, but we find that a combination of melting and mixing satisfactorily reproduces the melt inclusion geochemical variability. The relative roles of melting and mixing of different components can be partially deconvolved in a plot of ${ }^{87} \mathrm{Sr} /{ }^{86} \mathrm{Sr}$ versus $1 / \mathrm{Sr}$ (Fig. 8), where twocomponent mixing trajectories are linear and variable degrees of melting result in horizontal trajectories. The Ofu melt inclusions lie on a horizontal trend, which can be described by various degrees of melting of a single source that exhibits a ${ }^{87} \mathrm{Sr} /{ }^{86} \mathrm{Sr}$ ratio of $\sim 0.7045$, and the Malumalu and Vailulu'u melt inclusions form a diagonal array that suggests a role for two-component mixing.

\section{Discussion}

\subsection{A homogeneous source for PHEM basalts}

Compelling evidence that the Samoan melt inclusions sample a heterogeneous source comes from Sr-isotope analysis of the melt inclusions from Vailulu'u and Malumalu basalts. However, the uniformly unradiogenic character of the Ofu melt inclusions precludes a significant contribution from an enriched, radiogenic (EM2) component. This suggests that Samoan melts with high ${ }^{3} \mathrm{He} /{ }^{4} \mathrm{He}$ sample a homogeneous source and do not mix with melts of an enriched component. By comparison, the melt inclusions from Malumalu and Vailulu'u span a large range of $\mathrm{Sr}$ concentrations and isotopic compositions, indicating that both variable degrees of melting and mixing have occurred. An aggregated fractional melt trajectory for the garnet stability field is plotted (Fig. 8) for the EM2 source [4], and the Malumalu and Vailulu'u melt inclusions form a broad array that trends diagonally away from the horizontal Ofu melting trajectory toward low degree $(\sim 1 \%)$ melts of the EM2 source; the Vailulu'u and Malumalu melt inclusions can be produced by aggregated melts of an Ofu source that then mix with aggregated fractional garnet melts of the EM2 source.

Unlike the EM2 source, the trace element source composition of the high ${ }^{3} \mathrm{He} /{ }^{4} \mathrm{He}$, lower ${ }^{87} \mathrm{Sr} /{ }^{86} \mathrm{Sr} \mathrm{Ofu}$ source component is less clear. Called PHEM [23], this 

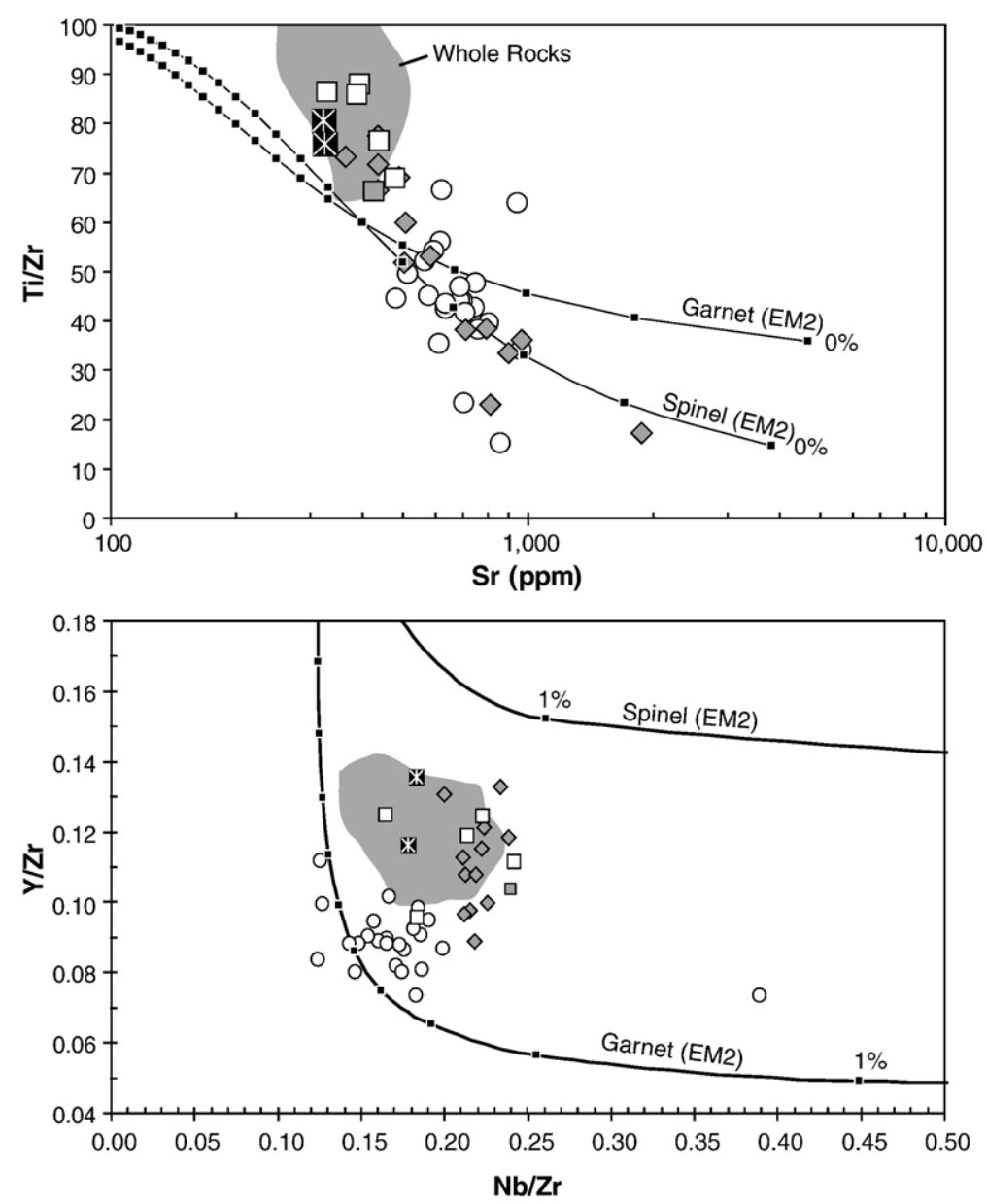

Fig. 6. Upper panel: Ti/Zr versus Sr concentration in melt inclusions and whole rocks with melting models. All melt inclusions and whole rocks are corrected for olivine fractionation to be in equilibrium with mantle olivine. Grey field is for whole-rock samples from Vailulu'u, Malumalu and Ofu. Lines with closed boxes represent aggregated fractional melting trends of the EM2 source [4] in the garnet and spinel stability fields, using partition coefficients from [33]. Harzburgite mineral modes are from [32]. All melting is non-modal. Tick marks are every $1 \%$ melting, beginning at $0 \%$ and increasing to the left. Lower panel: $\mathrm{Y} / \mathrm{Zr}$ versus $\mathrm{Nb} / \mathrm{Zr}$ in melt inclusions and whole rock, including melting models in the garnet and spinel stability fields. Tick marks are every $1 \%$ and the degree of melting increases to the left. Melting parameters and grey field are the same as upper panel.

component melts to form basalts and melt inclusions from Ofu. However, it is possible to bracket the source composition of this component and estimate the degree of melting captured in the Ofu melt inclusions. Although the Ofu basalts are more isotopically depleted than the EM2 basalts, an isotopically and trace element depleted DMM lherzolite source (7 ppm Sr) [35] fails to produce the high $\mathrm{Sr}$ concentrations observed in the Ofu melt inclusions (Fig. 7). This would suggest that the Ofu source is either more refractory or more trace element enriched, or both, than the lherzolitic [35] DMM source. The first option can be explored by invoking a more refractory, harzburgitic DMM source. However, only unreasonably low $(F<1 \%)$ degrees of melting can produce the most enriched Sr concentration observed an
Ofu melt inclusion. The second scenario can be tested by invoking the trace element enriched EM2 source, and assigning it a lherzolitic lithology that is similar to DMM. At reasonable degrees of melting $(F=1.5 \%)$, such a source can generate melts with sufficiently high $\mathrm{Sr}$ contents to match the range observed in Ofu. Finally, a harzburgitic EM2 source, which is both more refractory and trace element enriched than DMM, can generate the most enriched melt inclusions from Malumalu and Ofu between $1 \%$ and 2\% melting. The harzburgitic EM2 source can serve as a probable upper limit for the trace element enrichment of the PHEM source because we consider it unlikely for the less isotopically enriched PHEM component to exhibit greater trace element enrichment than EM2. However, 


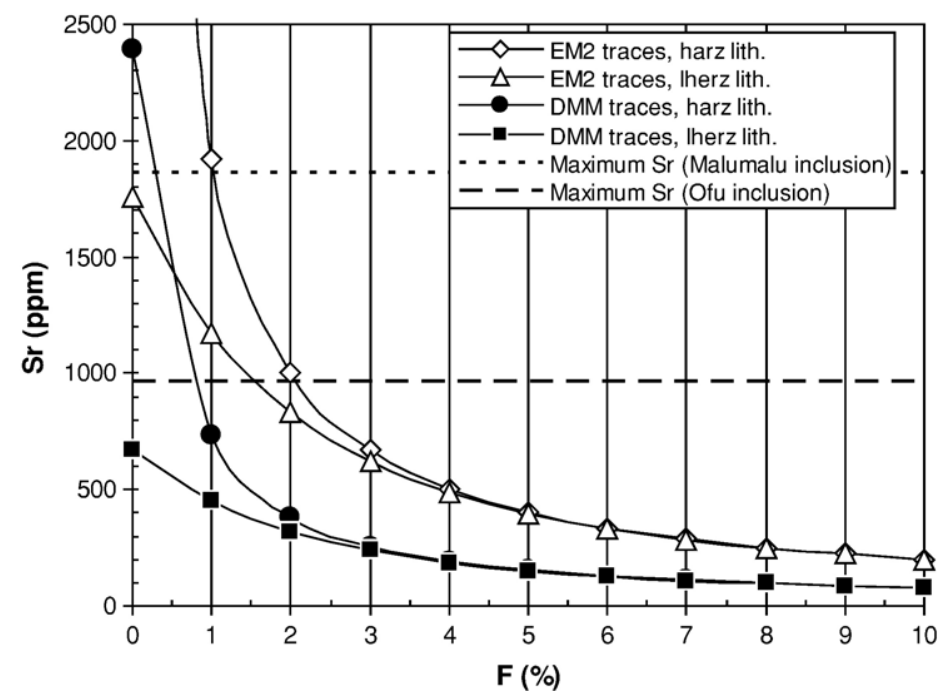

Fig. 7. Sr in melt versus degree of melting $(F)$ for various combinations of two lithologies and two trace element source abundances. Two dashed lines represent olivine fractionation-corrected $\mathrm{Sr}$ concentrations in the most enriched melt inclusions from Malumalu sample 78-1 (upper line) and Vailulu'u sample 71-2 (lower line). DMM trace element source and lherzolite lithology from [35], converted to equivalent garnet facies lithology using relationship from [34]. EM2 source from [4]. Harzburgite lithology from [32]. Note that only the EM2 source with a harzburgite lithology can produce the highest $\mathrm{Sr}$ concentration observed in the melt inclusion from sample 78-1 at $F \geq 1 \%$. All melting is non-modal in the garnet stability field. Neither modal melting nor melting in the spinel stability field significantly changes our conclusions at $F \geq 1 \%$.

a PHEM source with a lithology (and/or Sr concentrations) intermediate between DMM and EM2 cannot be ruled out. If PHEM has the same $\mathrm{Sr}$ content and lithology as the EM2 source, the Vailulu'u and Malumalu melt inclusion arrays can be explained as mixtures of $6.5 \pm 1.5 \%$ melts of PHEM and $\sim 1 \%$ melts of EM2. However, the degree of melting of the PHEM source that contributes to the Malumalu-Vailulu'u mixing array should be taken as a maximum.

Unlike the Ofu melt inclusions, which sample a pure PHEM source, no melt inclusions sample a pure EM2 melt (as calclulated by [4], using ultra-enriched Srisotope compositions from Samoan xenoliths [36]). Mixing lines in Fig. 8 between a 1\% EM2 melt and $6.5 \pm 1.5 \%$ PHEM melts indicate that the subset of Vailulu'u and Malumalu melt inclusions with both ${ }^{87} \mathrm{Sr} /$ ${ }^{86} \mathrm{Sr}$ and $\mathrm{Sr}$ concentration data are dominated by a PHEM component, and exhibit less than a $\sim 30 \%$ contribution from the EM2 component. However, one Malumalu melt inclusion exhibits a much larger contribution from an EM2 component, as indicated by its high $(\sim 1865 \mathrm{ppm})$ $\mathrm{Sr}$ content and low $(\sim 17) \mathrm{Ti} / \mathrm{Zr}$ ratio (Fig. 6). The PHEM-EM2 melt mixing lines in Fig. 8 suggest that this melt inclusion contains more than a $70 \%$ contribution from the EM2 melt component. The mixing model suggests that a $70 \%$ contribution from an EM2 melt would produce an extrapolated ${ }^{87} \mathrm{Sr} /{ }^{86} \mathrm{Sr}$ ratio of $\sim 0.712$, which is a significantly higher ratio than has been observed in a Samoan basalt, but close to the ${ }^{87} \mathrm{Sr} /$
${ }^{86} \mathrm{Sr}$ of cpx in metasomatized xenoliths from Savai'i in western Samoa. Unfortunately, this ultra-enriched melt inclusion was too small for isotopic analysis.

\subsection{Isotopic variability in Samoan melt inclusions: MORB or FOZO?}

Correlations between trace elements and $\mathrm{Sr}$ isotopes suggest that trace element variability in Samoan basalts and melt inclusions may reflect heterogeneity in the Samoan mantle. $\mathrm{Rb} / \mathrm{Sr}, \mathrm{K}_{2} \mathrm{O},(\mathrm{Ba} / \mathrm{Nb})_{\mathrm{N}}$ and $\mathrm{Nb} / \mathrm{Zr}$ ratios correlate with $\mathrm{Sr}$ isotopes in Samoan lavas and melt inclusions, suggesting that these trace elements are heterogeneous in the Samoan mantle source. However, a combination of melting processes and variable source lithology may drive the observed correlations, limiting the role for source heterogeneity. For example, the relatively constant $\mathrm{K}_{2} \mathrm{O}$ concentrations and negative (PUM-normalized) anomalies in Samoan lavas may be a result of residual phlogopite, which may cause $\mathrm{K}_{2} \mathrm{O}$ to behave more compatibly in the Samoan source during melting. However, $\mathrm{K}_{2} \mathrm{O}$ correlates with ${ }^{87} \mathrm{Sr} /{ }^{86} \mathrm{Sr}$ in the whole rocks and melt inclusions (Fig. 5), suggesting a role for $\mathrm{K}_{2} \mathrm{O}$ heterogeneity in the Samoan source, and that $\mathrm{K}_{2} \mathrm{O}$ concentrations in Samoan basalts and melt inclusions may be controlled only partially by melting processes.

Assuming that $\mathrm{Rb} / \mathrm{Sr}$ variability in Samoan melts reflects source variability, the array formed by the ${ }^{87} \mathrm{Sr} /$ 


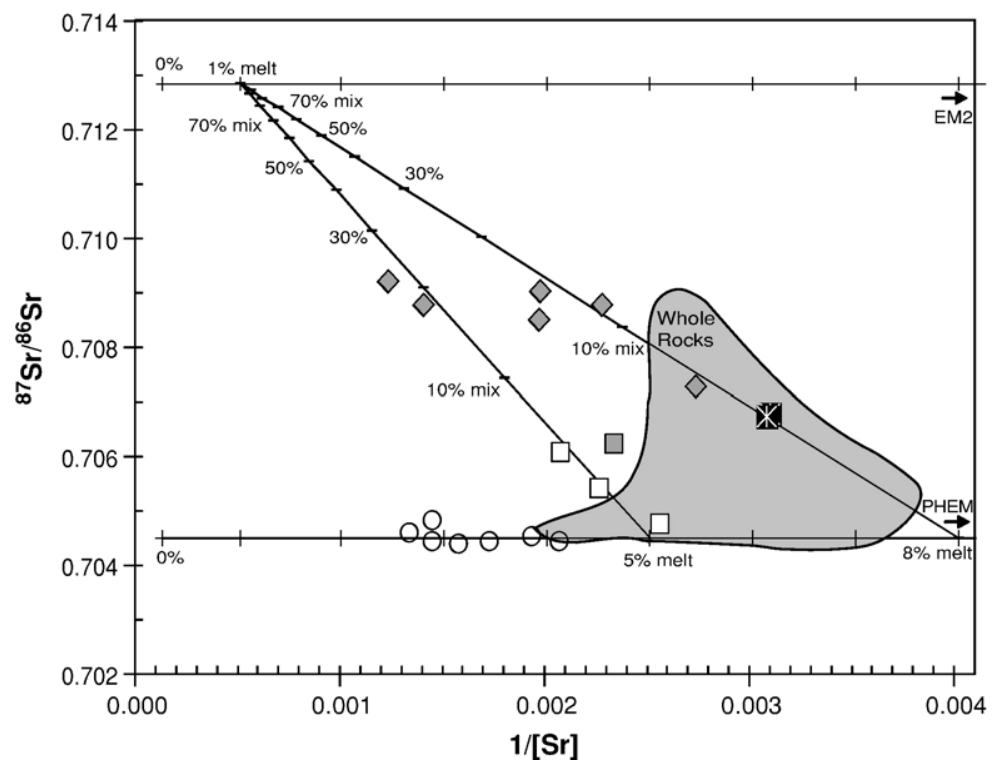

Fig. $8 .{ }^{87} \mathrm{Sr} /{ }^{86} \mathrm{Sr}$ versus $1 /[\mathrm{Sr}]$ for Samoan melt inclusions and basalts. Malumalu and Vailulu'u melt inclusions form a quasi-linear array extending away from the whole-rock basalts from Malumalu, Ofu and Vailulu'u (grey field, same as Fig. 6). Ofu melt inclusions fall off this array, plotting at lower ${ }^{87} \mathrm{Sr}{ }^{86} \mathrm{Sr}$ at a given $\mathrm{Sr}$ concentration. Aggregated non-modal fractional melting trends of the EM2 and PHEM sources in the garnet stability field are shown as horizontal lines (tick marks are every $1 \%$ melting, beginning at $0 \%$ and increasing to the right). Two mixing lines, both extending diagonally from a $1 \%$ EM2 melt to 5\% and 8\% PHEM melts, are shown (each tick represents $10 \%$ mixture, starting at $0 \%$ EM 2 and increasing to the upper left). Ofu melt inclusions lie on the melting trend for PHEM, and require no mixing with an EM2 component. Malumalu and Vailulu'u melt inclusions can be described by mixing of melts from the EM2 and PHEM sources. Sr concentrations in melt inclusions and whole rocks are corrected for olivine fractionation. PHEM and EM2 source compositions plot outside of the figure as indicated, at 1/Sr values of $\sim 0.05$ (Sr concentrations of $20.0 \mathrm{ppm}$ ). The published source for EM2 [4] is used in this figure. As a limit, PHEM is given the trace element source abundances and lithology of EM2 in the melt model. Symbols same as in Fig. 3.

${ }^{86} \mathrm{Sr}$ and $\mathrm{Rb} / \mathrm{Sr}$ data can be modeled as binary mixing between a PHEM and an EM2 component, a model originally proposed by Farley et al. [23]. Such a model is consistent with the trace element melting/mixing model proposed above, which suggests that the Ofu melt inclusions sample only a high ${ }^{3} \mathrm{He} /{ }^{4} \mathrm{He}$ PHEM mantle reservoir and the Vailulu'u and Malumalu melt inclusions result from mixing melts from both the PHEM and EM2 mantle reservoirs.

Previous work on the $\mathrm{Pb}$-isotopic variability in melt inclusions [17] suggested that the unradiogenic endmember in EM2 basalts from Tahaa may be depleted (MORB or FOZO?), and thus lie at even lower ${ }^{87} \mathrm{Sr} /{ }^{86} \mathrm{Sr}$ values than observed in the high ${ }^{3} \mathrm{He} /{ }^{4} \mathrm{He}$ PHEM lavas from Ofu (Fig. 3). In fact, an extrapolation of the Samoa melt inclusion and whole-rock basalt array in Fig. 3 does indeed trend toward one of two depleted components that are significantly less radiogenic than PHEM: MORB [22] or a common high ${ }^{3} \mathrm{He} /{ }^{4} \mathrm{He}$ mantle component, called FOZO [24] (Fig. 3). The FOZO component is represented by basalts with the highest ${ }^{3} \mathrm{He} /{ }^{4} \mathrm{He}$ from Hawaii [37], Iceland [38] and Baffin Island [39]. Both MORB and FOZO lie on a similar extension of the
Samoa melt inclusion ${ }^{87} \mathrm{Sr} /{ }^{86} \mathrm{Sr}-\mathrm{Rb} / \mathrm{Sr}$ array, so it is difficult to distinguish which, if either, of these two components is sampled by the Samoan melt inclusions. If the depleted component is MORB, it may be entrained in melt inclusions by shallow anatexis due to preferential cooling and olivine crystallization near magma chamber and conduit walls $[7,8,21]$. However, the presence of FOZO (or any other high ${ }^{3} \mathrm{He} /{ }^{4} \mathrm{He}$ component) in the Samoan melt inclusions would require that the isotopic variability in melt inclusions reflect true source heterogeneity, assuming that a high ${ }^{3} \mathrm{He} /{ }^{4} \mathrm{He}$ component does not exist in the oceanic crust or lithosphere.

\subsection{The case against MORB}

It may be possible to look at other lines of geochemical evidence to discern whether MORB or FOZO play a role in augmenting the isotopic diversity in Samoan melt inclusions. Models suggesting that melt inclusion isotopic variability is caused only by contamination from unradiogenic oceanic crust and lithosphere at shallow levels do not explain how several Samoan melt inclusions have higher ${ }^{87} \mathrm{Sr} /{ }^{86} \mathrm{Sr}$ ratios than their host 
bulk rock compositions (see Fig. 1). For example, Samoan whole-rock basalt sample 71-11 hosts several melt inclusions that have ${ }^{87} \mathrm{Sr} /{ }^{86} \mathrm{Sr}$ ratios (up to $0.70692)$ that are significantly more enriched than its host rock (0.70550). The presence of ${ }^{87} \mathrm{Sr} /{ }^{86} \mathrm{Sr}$ ratios in melt inclusions that are higher than the bulk rock require that at least some of the isotopic variability present in melt inclusions is derived from the mantle source, because the enriched component in melt inclusion 71-11a is too enriched to be found in the oceanic crust and lithosphere. Therefore, if assimilation of oceanic crust and lithosphere contributes heterogeneity to the Samoan melt inclusions, it cannot be the only means by which isotopic heterogeneity is produced in Samoan melt inclusions, and some contribution from the melt source must be involved as well.

On a different tack, the case for the less radiogenic melt inclusions sampling the depleted oceanic crust and lithosphere by assimilation is limited severely by the observation that, within analytical uncertainty, not a single melt inclusion has an ${ }^{87} \mathrm{Sr} /{ }^{86} \mathrm{Sr}$ ratio that is lower than the least radiogenic $\left({ }^{87} \mathrm{Sr} /{ }^{86} \mathrm{Sr}=0.7044\right)$ wholerock basalt measured in the Samoan islands (Fig. 1). The Samoan melt inclusions trace out a range of Sr-isotope variability that is confined to the region of Sr-isotope space defined by the Samoan whole-rock data (Fig. 3). On an island-by-island basis, the interpretation is more complicated, as melt inclusions from two Vailulu'u whole-rocks sample a component more depleted than found in whole rocks measured from the seamount. However, the least radiogenic component found in Vailulu'u melt inclusions is also found in lavas from nearby Samoan islands (e.g., Ta'u and Ofu), exhibits elevated ${ }^{3} \mathrm{He} /{ }^{4} \mathrm{He}$ ratios, and is thus known to exist in the Samoan plume. Many of the downstream Samoan seamounts also are dominated by ${ }^{87} \mathrm{Sr} /{ }^{86} \mathrm{Sr}$ between 0.7044 and 0.7049 [3]. It seems unnecessary, therefore, to invoke contamination from the oceanic crust and lithosphere to explain the presence of the less radiogenic component when it already exists inside the plume! Although the argument can be made that an insufficient number of melt inclusions have been analyzed to detect a component more depleted than what is found in whole rocks, the number of melt inclusions analyzed for $\mathrm{Sr}$ isotopes $(n=41)$ is already significant, and is equal to $\sim 30 \%$ of the number of published ${ }^{87} \mathrm{Sr} /{ }^{86} \mathrm{Sr}$ whole-rock analyses from the Samoan hotspot.

The high ${ }^{3} \mathrm{He} /{ }^{4} \mathrm{He}$, unradiogenic $\mathrm{Sr}$ component in Samoan basalts (PHEM) is unique in that it exhibits ${ }^{87} \mathrm{Sr} /{ }^{86} \mathrm{Sr}$ ratios more enriched than in the high ${ }^{3} \mathrm{He} /{ }^{4} \mathrm{He}$ Hawaii, Iceland or Baffin Island basalts, suggesting that the high ${ }^{3} \mathrm{He} /{ }^{4} \mathrm{He}$ reservoir in the mantle is at least mildly heterogeneous in ${ }^{87} \mathrm{Sr} /{ }^{86} \mathrm{Sr}$ ratios. The same line of reasoning that precludes the presence of entrained melts from oceanic lithosphere in the Samoan melt inclusions also minimizes the possibility that a traditional, depleted FOZO-like component $\left({ }^{87} \mathrm{Sr} /{ }^{86} \mathrm{Sr}=0.7030\right.$ [24] $)$ serves as the unradiogenic $\mathrm{Sr}$ component: If melt inclusion diversity were a result of entrainment of a component (MORB or FOZO) more depleted than found in Samoan basalts, then the melt inclusions would extend to ${ }^{87} \mathrm{Sr} /$ ${ }^{86} \mathrm{Sr}$ ratios lower than found in whole rocks $(0.7044)$. However, the high ${ }^{3} \mathrm{He} /{ }^{4} \mathrm{He}$ Samoan sample OFU-0406 defines the lowest ${ }^{87} \mathrm{Sr} /{ }^{86} \mathrm{Sr}$ portion of the Samoan whole-rock mixing array (see Fig. 3) and the melt inclusions are identical to the whole rock, suggesting that the least radiogenic $\mathrm{Sr}$ composition sampled by the Ofu basalts is the same component found in the melt inclusions. Therefore, we maintain that the unradiogenic $\mathrm{Sr}$ component in Samoan melt inclusions is more enriched than MORB or FOZO, and is likely the same PHEM component sampled by the high ${ }^{3} \mathrm{He} /$ ${ }^{4} \mathrm{He}$ Samoan basalts, suggesting that a two-component EM2-PHEM mixing model may be the most appropriate for melt inclusions originating in the enriched Samoan mantle. Scatter around such a mixing model (Fig. 8) may be due to minor contributions from other components [4] that may exist in the Samoan mantle.

\subsection{Implications for source heterogeneity (or lack thereof)}

The results for Sr-isotope measurements in Samoan melt inclusions support an argument for an origin of the isotopic variability in the melt source, not contamination by oceanic crust and lithosphere. We assume that the isotopic variability (or lack thereof) in Samoan melt inclusions is not a product of variable degrees of homogenization in magma conduits and chambers before olivine entrapment, but rather that the isotopic variability in melt inclusions reflects the heterogeneity of the melt source: When the melt source is heterogeneous, melt inclusions capture the range of heterogeneity while the isotopic composition of the bulk rock lava represents an average of the heterogeneity sampled in the melt. By extension, we infer that the high ${ }^{3} \mathrm{He} /{ }^{4} \mathrm{He}$ whole-rock sample OFU-04-06 tends to sample a more homogeneous source, as the melt inclusions are nearly isotopically homogeneous and identical to the bulk rock. Perhaps, then, only melting of a pure PHEM source allows the high ${ }^{3} \mathrm{He} /{ }^{4} \mathrm{He}$ composition to persist in the 
Ofu whole-rock lavas. Vailulu'u and Malumalu melt inclusions are more isotopically heterogeneous, and thus are inferred to sample a heterogeneous source that captures much of the mixing spectrum between the EM2 and PHEM components. The contribution of an EM2 component may explain the diminished ${ }^{3} \mathrm{He} /{ }^{4} \mathrm{He}$ composition in the lavas from these two volcanoes. Although ${ }^{87} \mathrm{Sr} /{ }^{86} \mathrm{Sr}$ analyses of the melt inclusions from high ${ }^{3} \mathrm{He} /{ }^{4} \mathrm{He}$ basalts from other localities are not yet available, perhaps the high ${ }^{3} \mathrm{He} /{ }^{4} \mathrm{He}$ mantle that these basalts sample is homogeneous and devoid of enriched domains. This hypothesis is consistent with the melting-mixing model above (see Fig. 8), which suggests that the isotopically homogeneous melt inclusions from the high ${ }^{3} \mathrm{He} /{ }^{4} \mathrm{He}$ basalt from Ofu exhibit no evidence of mixing with an EM2 component.

It is notable that while near-pure PHEM melts are observed in Samoan melt inclusions, pure EM2 melts $\left({ }^{87} \mathrm{Sr} /{ }^{86} \mathrm{Sr}=0.7128[4,36]\right)$ were not unequivocally detected in this study (i.e., by measurement of $\mathrm{Sr}$ isotopes). Several melt inclusions with ultra-enriched trace element patterns were observed, but most of the melt inclusions are composed of $<30 \%$ EM2 component. Perhaps this indicates that, compared to the PHEM component, the EM2 component in the Samoan plume is rare. Alternatively, the EM2 component may not be rare in the Samoan plume, but is more refractory and produces less melt than the PHEM component. In this way, perhaps, EM2 melts are less frequently sampled by melt inclusions. Future work on melt inclusions will help resolve the relative contributions of the enriched and high ${ }^{3} \mathrm{He} /{ }^{4} \mathrm{He}$ sources to OIB lavas.

\section{Summary}

The following conclusions can be drawn from this study:

1.) The Sr-isotopic diversity in melt inclusions from Samoan basalts does not extend significantly above or below the range defined by whole rocks from the Samoan hotspot.

2.) A few melt inclusions exhibit ${ }^{87} \mathrm{Sr} /{ }^{86} \mathrm{Sr}$ ratios significantly higher than their host whole rock. This is taken as evidence that assimilation of MORB lithosphere cannot be the only mechanism that contributes isotopic diversity to the melt inclusions

3.) The ${ }^{87} \mathrm{Sr} /{ }^{86} \mathrm{Sr}$ ratio of the high ${ }^{3} \mathrm{He} /{ }^{4} \mathrm{He}$ basalt is essentially indistinguishable from the $\mathrm{Sr}$-isotope ratios (0.7044) measured in its melt inclusions, and the ${ }^{87} \mathrm{Sr} /{ }^{86} \mathrm{Sr}$ ratios in melt inclusions from other Samoan basalts do not exhibit ratios lower than 0.7044 . This observation is consistent with the hypothesis that a high ${ }^{3} \mathrm{He} /{ }^{4} \mathrm{He}$ component, not MORB, is the unradiogenic $\mathrm{Sr}$ endmember in Samoan melt inclusions.

4.) Melt inclusions from a high ${ }^{3} \mathrm{He} /{ }^{4} \mathrm{He}$ Samoan basalt (with less radiogenic ${ }^{87} \mathrm{Sr} /{ }^{86} \mathrm{Sr}$ ) are isotopically more homogeneous than the melt inclusions from basalts with higher ${ }^{87} \mathrm{Sr} /{ }^{86} \mathrm{Sr}$ (more contribution from an EM2 component). This may indicate that the Samoan high ${ }^{3} \mathrm{He} /{ }^{4} \mathrm{He}$ basalts sample a source that is more isotopically homogeneous than the source that produces basalts with an EM2 component.

\section{Acknowledgements}

We thank Lary Ball for his generous analytical wizardry with the NEPTUNE. J. Blusztajn and R. Workman helped document the Sr-isotope basalt glass standards. We also thank N. Shimizu, A. Saal, M. Kurz, J. Wang, A. Koleszar and C. Waters for discussions. Simon Thorrold loaned us his sclerosponge standards, and helped with many technical discussions arising from his unparallel laser ablation Sr isotope work on carbonates. Frank Ramos provided a preprint of his paper, and numerous insightful discussions. Reviews from Vincent Salters and an anonymous reviewer greatly improved the manuscript. An NSF Graduate Research Fellowship is gratefully acknowledged (to MGJ). This research was supported by NSF grant EAR-0125917 (to SRH).

\section{Appendix A. Supplementary data}

Supplementary data associated with this article can be found, in the online version, at doi:10.1016/j.epsl. 2006.02.040.

\section{References}

[1] A. Zindler, S.R. Hart, Chemical geodynamics, Annu. Rev. Earth Planet. Sci. 14 (1986) 493-571.

[2] A.W. Hofmann, Mantle geochemistry: the message from oceanic volcanism, Nature 385 (1997) 219-229.

[3] S.R. Hart, M. Coetzee, R.K. Workman, J. Blusztajn, K.T.M. Johnson, J.M. Sinton, B. Steinberger, J.W. Hawkins, Genesis of the Western Samoa seamount province: age, geochemical fingerprint and tectonics, Earth Planet. Sci. Lett. 227 (2004) 37-56.

[4] R.K. Workman, S.R. Hart, M. Jackson, M. Regelous, K.A. Farley, J. Blusztajn, M. Kurz, H. Staudigel, Recycled metasomatized lithosphere as the origin of the Enriched Mantle II (EM2) endmember: evidence from the Samoan volcanic chain, Geochem. Geophys. Geosyst. 5 (2004), doi:10.1029/2003GC000623. 
[5] W.J. Morgan, Convection plumes in the lower mantle, Nature 230 (1971) 42-43.

[6] R.K. Workman, E. Hauri, S.R. Hart, J. Wang, J. Blusztajn, Volatile and trace elements in basaltic glasses from Samoa: implications for water distribution in the mantle, Earth Planet. Sci. Lett. 24 (2006) 932-951.

[7] L.V. Danyushevsky, M.R. Perfit, S.M. Eggins, T.J. Falloon, Crustal origin for coupled 'ultra-depleted' and 'plagioclase' signatures in MORB olivine-hosted melt inclusions: evidence from the Siquieros Transform Fault, East Pacific Rise, Contrib. Mineral. Petrol 144 (2003) 619-637.

[8] L.V. Danyushevsky, R.A.J. Leslie, A.J. Crawford, P. Durance, Melt inclusions in primitive olivine phenocrysts: the role of localized reaction processes in the origin of anomalous compositions, J. Pet. 45 (2004) 2531-2553.

[9] A.V. Sobolev, N. Shimizu, Ultra-depleted primary melt included in an olivine from the Mid-Atlantic Ridge, Nature 363 (1993) 151-154.

[10] A.A. Gurenko, M. Chaussidon, Enriched and depleted primitive melts included in olivine from Icelandic tholeiites: origin by continuous melting of a single mantle column, Geochim. Cosmochim. Acta 59 (1995) 2905-2917.

[11] J.C. Lassiter, E.H. Hauri, I.K. Nikogosian, H.G. Barsczus, Chlorine-potassium variations in melt inclusions from Raivavae and Rapa, Austral Islands: constraints on chlorine recycling in the mantle and evidence for brine-induced melting of oceanic crust, Earth Planet. Sci. Lett. 202 (2002) 525-540.

[12] E. Cottrell, M. Spiegelman, C.H. Langmuir, Consequences of diffusive reequilibration for the interpretation of melt inclusions, Geochem. Geophys. Geosyst. 3 (2002), doi:10.1029/2001GC000205.

[13] G.A. Gaetani, E.B. Watson, Modeling the major-element evolution of olivine-hosted melt inclusions, Chem. Geol. 183 (2002) 25-41.

[14] G.A. Gaetani, E.B. Watson, Open system behavior of olivinehosted melt inclusions, Earth Planet. Sci. Lett. 183 (2000) 27-41.

[15] P. Schiano, R. Clocchiatti, Worldwide occurrence of silica-rich melts in sub-continental and sub-oceanic mantle minerals, Nature 368 (1994) 621-624.

[16] V. Kamenetsky, Methodology for the study of melt inclusions in Cr-spinel, and implications for parental melts of MORB from FAMOUS area, Earth Planet. Sci. Lett. 142 (1996) 477-484.

[17] A.E. Saal, S.R. Hart, N. Shimizu, E.H. Hauri, G.D. Layne, $\mathrm{Pb}$ isotopic variability in melt inclusions from oceanic island basalts, Polynesia, Science 282 (1998) 1481-1484.

[18] K. Kobayashi, R. Tanaka, T. Moriguti, K. Shimizu, E. Nakamura, Lithium, boron, and lead isotope systematics of glass inclusions in olivines from Hawaiian lavas: evidence for recycled components in the Hawaiian plume, Chem. Geol. 212 (2004) 143-161.

[19] H. Yurimoto, T. Kogiso, K. Abea, H.G. Barsczus, A. Utsunomiya, S. Maruyama, Lead isotopic compositions in olivinehosted melt inclusions from HIMU basalts and possible link to sulfide components, Phys. Earth Planet. Inter. 146 (2004) 231-242.

[20] K.P. Jochum, B. Stoll, A.W. Hofmann, Pb isotopes and trace elements in melt inclusions from Hawaiian basalts using LA-ICPMS and SRXRF, Geochim. Cosmochim. Acta 68 (Sup.1) (2004) A564.

[21] A.E. Saal, S.R. Hart, N. Shimizu, E.H. Hauri, G.D. Layne, J.M. Eiler, $\mathrm{Pb}$ isotopic variability in melt inclusions from the EMIEMII-HIMU mantle end-members and the role of the oceanic lithosphere, Earth Planet. Sci. Lett. 240 (2005) 605-620.

[22] Y. Su, C.H. Langmuir, Global MORB chemistry compilation at the segment scale, Ph.D. Thesis, Department of Earth and Environ- mental Sciences, Columbia University (2003). Available at: http:// petdb.ldeo.columbia.edu/documentation/morbcompilation/.

[23] K.A. Farley, J.H. Natland, H. Craig, Binary mixing of enriched and undegassed (primitive?) components $(\mathrm{He}, \mathrm{Sr}, \mathrm{Nd}, \mathrm{Pb})$ in Samoan lavas, Earth Planet. Sci. Lett. 111 (1992) 183-199.

[24] S.R. Hart, E.H. Hauri, L.A. Oschmann, J.A. Whitehead, Mantle plumes and entrainment-isotopic evidence, Science 256 (1992) 517-520.

[25] M.G. Jackson, M.D. Kurz, S.R. Hart, R. Workman, Implications of new high ${ }^{3} \mathrm{He} /{ }^{4} \mathrm{He}$ values from the Samoan hotspot, Abstr. EOS Tran. AGU, 86, Fall Meet. Suppl., 2005, pp. V41D-V1485.

[26] F.C. Ramos, J.A. Wolff, D.L. Tollstrup, Measuring ${ }^{87} \mathrm{Sr} /{ }^{86} \mathrm{Sr}$ variations in minerals and groundmass from basalts using LAMC-ICPMS, Chem. Geol. 211 (2004) 135-158.

[27] N. Shimizu, C.J. Allegre, Geochemistry of transition elements in garnet lherzolite nodules in kimberlites, Contrib. Mineral. Petrol. 67 (1978) 41-50.

[28] N. Shimizu, A.P. Le Roex, The chemical zoning of augite phenocrysts in alkaline basalts from Gough Island, South Atlantic, J. Volcanol. Geotherm. Res. 29 (1978) 149-199.

[29] P.L. Roeder, R.F. Emslie, Olivine-liquid equilibrium, Contrib. Mineral. Petrol. 29 (1970) 275-289.

[30] W.F. McDonough, S.S. Sun, The composition of the Earth, Chem. Geol. 120 (1995) 223-253.

[31] N. Shimizu, The geochemistry of olivine-hosted melt inclusions in a FAMOUS basalt ALV519-4-1, Phys. Earth Planet. Inter. 107 (1998) 183-201.

[32] H.J.B. Dick, R.L. Fisher, W.B. Bryan, Mineralogic variability of the uppermost mantle along the mid-ocean ridges, Earth Planet. Sci. Lett. 69 (1984) 88-106.

[33] P.B. Kelemen, G.M. Yogodzinski, D.W. Scholl, Along-strike variation in lavas of the Aleutian island arc: implications for the genesis of high $\mathrm{Mg} \#$ andesite and the continental crust, in: J. Eiler (Ed.), Inside the Subduction Factory, AGU Monograph, vol. 138, AGU, 2004, pp. 223-276.

[34] E. Takazawa, F. Frey, N. Shimizu, M. Obata, Evolution of the Horoman peridotite (Hokkaido, Japan): implications from pyroxenite compositions, Chem. Geol. 134 (1996) 3-26.

[35] R.K. Workman, S.R. Hart, Major and trace element composition of the depleted MORB mantle (DMM), Earth Planet. Sci. Lett. 231 (2005) 53-72.

[36] E.H. Hauri, N. Shimizu, J. Dieu, S.R. Hart, Evidence for hotspotrelated carbonatite metasomatism in the oceanic upper mantle, Nature 365 (1993) 221-227.

[37] M.D. Kurz, W.J. Jenkins, S.R. Hart, D. Clague, Helium isotopic variations in volcanic rocks from Loihi seamount and the Islands of Hawaii, Earth Planet. Sci. Lett. 66 (1983) 388-406.

[38] D.R. Hilton, K. Grönvold, C.G. Macpherson, P.R. Castillo, Extreme ${ }^{3} \mathrm{He} /{ }^{4} \mathrm{He}$ ratios in northwest Iceland: constraining the common component in mantle plumes, Earth Planet. Sci. Lett. 173 (1999) 53-60.

[39] F.M. Stuart, S. Lass-Evans, J.G. Fitton, R.M. Ellam, High ${ }^{3} \mathrm{He} /$ ${ }^{4} \mathrm{He}$ ratios in picritic basalts from Baffin Island and the role of a mixed reservoir in mantle plumes, Nature 424 (2003) 57-59.

[40] P.J. Valbracht, T. Staudacher, A. Malahoff, C.J. Allegre, Noble gas systematics of deep rift zone glasses from Loihi Seamount, Hawaii, Earth Planet. Sci. Lett. 150 (1997) 399-411.

[41] S. Lass-Evans, The anatomy of the ancestral Iceland plume: a chemical and isotopic study of the Tertiary basalts and picrites from Baffin Island, Ph.D. Thesis, School of GeoSciences, University of Edinburgh (2005). 


\title{
Background Datasets Text,Figs\&Tables
Click here to download Background Datasets: SuppDataFigsTables.pdf \\ Background Datasets Text,Figs\&Tables
Click here to download Background Datasets: SuppDataFigsTables.pdf
} (

\author{
(a)
}

(n)

(n)

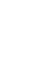

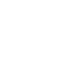

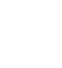

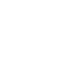
(1) (1) $\sqrt{3}$ (1) (1)

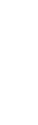

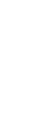
.

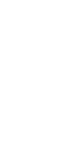
更 . . . . . . . . . . . . 


\section{Supplementary Data (Jackson and Hart, 2006)}

\section{Sr isotopes by laser ablation PIMMS: Application to Samoan basaltic melt inclusions}

\section{Introduction}

We have thoroughly, but not exhaustively, investigated the parameters necessary for precise and accurate $\mathrm{Sr}$ isotope analysis of basalt glasses by in situ laser ablation PIMMS. The lower limit of external precision attained under optimal conditions for the SRM987 Sr solution standard is $\pm 5 \mathrm{ppm}(>25$ volt data, $1 \sigma)$, and is fairly comparable to good TIMS data. For lower intensity data ( 1-5 volts), more comparable to our typical laser ablation work, the external solution precision is in the $20-80 \mathrm{ppm}$ range. We have instituted a new method for $\mathrm{Kr}$ correction that is based on ${ }^{84} \mathrm{Kr}$, and a method for $\mathrm{Rb}$ correction that utilizes basalt glass standards with significant $\mathrm{Rb} / \mathrm{Sr}$ ratios and known ${ }^{87} \mathrm{Sr} /{ }^{86} \mathrm{Sr}$ ratios. Even in basalts requiring very large $\mathrm{Rb}$ corrections, we are able to obtain ${ }^{87} \mathrm{Sr} /{ }^{86} \mathrm{Sr}$ data with $\sim 320 \mathrm{ppm}$ external precision and $45 \mathrm{ppm}$ internal (in-run) precision ( $2 \sigma$ standard deviation) on a suite of Samoan glasses with known ${ }^{87} \mathrm{Sr} /{ }^{86} \mathrm{Sr}$ ratios.

We developed an analytical protocol for the measurement of $\mathrm{Sr}$ isotope ratios by Laser Ablation PIMMS for analysis of melt inclusions in olivine phenocrysts in OIBs (ocean island basalts) from the EM2 (Samoa), EM1 (Pitcairn, Christmas) and HIMU (Mangaia) mantle end-members. We acknowledge a significant existing body of work on Sr isotope measurement by laser ablation PIMMS, but will not attempt to review this literature or compare it with the protocols we have installed on the NEPTUNE at the Woods Hole Oceanographic Institution [1-6].

\section{Techniques}

\subsection{Instrumental Description}

The data discussed here were obtained with a ThermoFinnigan NEPTUNE multicollector ICP-MS, coupled to a NEW Wave UP213 laser, housed in the Plasma Facility at the Woods Hole Oceanographic Institution. This NEPTUNE was installed in June 2003, replacing an earlier one that had been installed in February 2002, but damaged by the October 2002 fire in the Ion Probe Facility.

The typical operating parameters of the NEPTUNE and laser are given in Table 1 (note that our techniques have evolved over time, and some earlier data may have utilized somewhat different protocols). Currently, we aspirate clean dilute (5\%) nitric acid during the lasering, to allow solution standards to be interspersed with laser runs when needed. The arrangement of Faraday cups, and the relevant isotopic masses that are collected, is given in Table 2. Amplifiers are not rotated, as this rotates the Faraday (off-mass)

baselines as well. The mean raw Faraday intensities are transferred after all analyses to an offline data reduction program (TweaKr), for the various corrections.

We have opted to run the laser at $100 \%$ power and in apertured mode. While we could likely emplace higher energy density in focused mode, this tends to throw off larger chips and particles, particularly from basalt glass samples. We have not made any 
investigations of the effects of particle size on mass bias, interferences, and the like. Each analysis takes about 6.5 minutes of lasering, including offpeak baseline integration for 64 seconds and 20 cycles of 16 second integrations (and, more recently, 40 cycles of 8 second integrations). With a $120 \mu \mathrm{m}$ spot and $200 \mu \mathrm{m}$ long raster lines (see Table 1), spaced at only $20 \mu \mathrm{m}$, the final ablation pit is pyramidal, approximately $300 \times 300 \mu \mathrm{m}$, and $250 \mu \mathrm{m}$ deep. Typically, there will be little or no drift of ${ }^{88} \mathrm{Sr}$ intensity with time during ablation of homogeneous basalt glass standards, and the $1 \sigma$ standard deviation of intensity will fall in the range $5-15 \%$.

\subsection{Standards and Canonical Isotope Abundances}

For $\mathrm{Rb}$ and $\mathrm{Sr}$ isotope standards, we have used NIST standards SRM984 and SRM987. The certified values for these standards are listed in Table 3, along with the quoted uncertainties. Note that ${ }^{85} \mathrm{Rb} /{ }^{87} \mathrm{Rb}$ in SRM 984 is only certified to $\pm 423 \mathrm{ppm}$, ${ }^{87} \mathrm{Sr} /{ }^{86} \mathrm{Sr}$ and ${ }^{88} \mathrm{Sr} /{ }^{86} \mathrm{Sr}$ to only $380 \mathrm{ppm}$, and ${ }^{84} \mathrm{Sr} /{ }^{86} \mathrm{Sr}$ to $0.25 \%$. It is likely that the uncertainties in ${ }^{87} \mathrm{Sr} /{ }^{86} \mathrm{Sr}$ and ${ }^{88} \mathrm{Sr} /{ }^{86} \mathrm{Sr}$ are not independent, but possibly related by some fractionation-dependence. Note also that the certified ${ }^{86} \mathrm{Sr} /{ }^{88} \mathrm{Sr}$ value is 0.1193515 , not the consent value of 0.119400 adopted by the community. We have corrected all of the SRM 987 certificate ratios, by exponential law, to be consistent with the consent value of 0.1194 . Ironically, this results in a "corrected" ${ }^{87} \mathrm{Sr} /{ }^{86} \mathrm{Sr}$ ratio of 0.7101938 , which is lower than (but marginally within errors of) the value commonly adopted by the community of 0.710240 (which is itself different from the "uncorrected" certificate value of 0.710339 ). It will obviously be important for published papers to be very clear as to their usage of SRM 987 standard values. For Kr, we adopt the isotope abundances compiled by Ozima and Podosek (2001).

\subsection{Backgrounds and Baselines}

The NEPTUNE software allows a choice of baseline protocols. PIMMS users frequently use "on-peak" baselines, after sample wash-out [1, 3-6]; the NEPTUNE also allows a "defocused" beam baseline. Our experience is that baselines can be measurably $(>50 \mu \mathrm{V})$ elevated across a broad mass region during actual sample analysis and thus different from those measured in a defocused "beam-off" state, or while running gas or acid blanks. We have chosen therefore to adopt the common TIMS procedure of running "off-peak" baselines while sample analysis is underway; while this consumes part of the sample, we see no other way to ensure reliability of baselines. (However, baselines on Samoan basalt standards and basaltic melt inclusions do not change significantly over the course of an analytical session, and we have adopted the practice of applying baselines from larger melt inclusions - run during the same analytical session - to exceptionally small melt inclusions to save precious material). We have chosen to measure baselines at a position $0.70 \mathrm{amu}$ below each mass; this avoids potential baseline interferences from doubly-charged half-mass REE peaks, allows the Faradays that are intentionally set at 83.5 and 85.5 in order to monitor these $\mathrm{REE}^{+2}$ to offset 0.2 amu below mass 83 and 85 during baseline measurement, and places the ${ }^{88} \mathrm{Sr}$ cup near the minimum in the valley between ${ }^{87} \mathrm{Sr}$ and ${ }^{88} \mathrm{Sr}$ during baseline measurement. With this protocol, the only baseline that will have a significant tail contribution is ${ }^{87} \mathrm{Sr}$. With the measured abundance sensitivity at $\mathrm{Sr}$ mass of $\sim 1 \mathrm{ppm}$ at $1 \mathrm{amu}$, the ${ }^{87} \mathrm{Sr} /{ }^{86} \mathrm{Sr}$ ratio will be elevated by $<12$ 
ppm; this error is small compared to our external precision goal, and will also be normalized, to first order, through the use of the SRM987 standard.

\subsection{Kr Correction}

As is well known, there are interferences at ${ }^{84} \mathrm{Sr}$ and ${ }^{86} \mathrm{Sr}$ masses from $\mathrm{Kr}$. Conventionally, the $\mathrm{Kr}$ is considered to be a contaminant in the Ar plasma gas, and is corrected by measurement of ${ }^{82} \mathrm{Kr}$ or ${ }^{83} \mathrm{Kr}$. Over the past two years of measurement here, our ${ }^{83} \mathrm{Kr}$ intensity has varied from $\sim 0.05 \mathrm{mV}$ to $\sim 20 \mathrm{mV}$, and we believe that not all of it comes in with the argon, nor is all of mass 83 actually $\mathrm{Kr}$. Typically, after changing samples in the laser cell, there is a component of air $\mathrm{Kr}$ which slowly decreases as the chamber is purged. Ultimately, the $\mathrm{Kr}$ intensity with He flowing from the cell into the machine will decrease substantially below that in aspirated solutions (because the He has less $\mathrm{Kr}$ than the argon). It appears to us that there is a component of atmospheric $\mathrm{Kr}$ dissolved in aspirated solutions and this contributes to the $\mathrm{Kr}$ background. This could be possibly moderated by hermetically isolating the solutions from the atmosphere. Air entrainment by the plasma at the torch is also probable, but has proven difficult to constrain.

We have typically measured both ${ }^{82} \mathrm{Kr}$ and ${ }^{83} \mathrm{Kr}$ during all $\mathrm{Sr}$ analyses. Deviations of up to a factor of two from the canonical ${ }^{83} \mathrm{Kr} /{ }^{82} \mathrm{Kr}$ ratio of $\sim 1$ are very common in laser runs, with values most often above one, but also frequently below one (Fig. 1). Even solution runs on the 987 standard will frequently show $10-20 \%$ deviations from a ratio of 1 , typically with the ratios being too low (interferences on mass 82 ). Clearly there exist isobaric interferences that seriously hamper efforts to use either of these masses to correct for $\mathrm{Kr}$. We have adopted an alternative scheme which basically uses the most abundant $\mathrm{Kr}$ isotope at mass $84(\sim 57 \%)$ to make the $\mathrm{Kr}$ correction on mass 86 . This mass has a $\mathrm{Sr}$ "interference" on it, but for ${ }^{88} \mathrm{Sr}$ intensities in the 1-2 volt range, the Kr makes up $35-75 \%$ of the mass 84 peak (i.e. the $\mathrm{Kr}$ and $\mathrm{Sr}$ are approximately equal in intensity). By "subtracting" $\mathrm{Kr}$ until the ${ }^{84} \mathrm{Sr} /{ }^{88} \mathrm{Sr}$ ratio equals the canonical value of 0.00675476 (while iterating the mass-bias correction), this allows a robust correction to be made on mass 86 (there is a large error demagnification in this process, due to the fact that ${ }^{86} \mathrm{Kr} /{ }^{84} \mathrm{Kr}$ is 0.30 , while the ${ }^{86} \mathrm{Sr} /{ }^{84} \mathrm{Sr}$ ratio is $\left.\sim 17.7\right)$. Obviously, this technique relies on the absence of any other significant isobaric interferences at mass 84 ; in any event, these are likely to be less fatal than those at mass 83 , because of the ${ }^{84} \mathrm{Kr} /{ }^{83} \mathrm{Kr}$ ratio of $\sim 5$. One indication that this calculation method is helpful is the observation that the external precision of samples and standards run at low-intensity (1-2 volts on mass 88$)$ is typically improved by $30-50 \%$, compared to the same data corrected with ${ }^{83} \mathrm{Kr}$. Further discussion of isobaric interference issues may be found in section II $F$, below.

We are able to correct for $\mathrm{Kr}$ interferences so that elevated $\mathrm{Kr} / \mathrm{Sr}$ ratios do not noticeably diminish the precision or accuracy of glass analysis while using our protocol, provided that the ${ }^{88} \mathrm{Sr}$ intensity is $>1 \mathrm{~V}$ and ${ }^{82} \mathrm{Kr} /{ }^{88} \mathrm{Sr}$ is $<0.004$ (Table 4). At exceptionally high $\mathrm{Kr} / \mathrm{Sr}$ ratios, there may be a tendency for measurement precision to degrade. Therefore, analyses of unknowns that exhibit high $\mathrm{Kr} / \mathrm{Sr}$ ratios $\left({ }^{82} \mathrm{Kr} /{ }^{88} \mathrm{Sr}>\right.$ $0.004)$ are discarded.

Uncertainty in the isotopic ratios of $\mathrm{Kr}$ used in our correction scheme does not significantly contribute to diminishing the accuracy of ${ }^{87} \mathrm{Sr} /{ }^{86} \mathrm{Sr}$ analyses by laser ablation. At elevated $\mathrm{Kr} / \mathrm{Sr}\left({ }^{82} \mathrm{Kr} /{ }^{88} \mathrm{Sr}=0.004\right)$ - where such uncertainties will play the 
largest role in affecting the final $\mathrm{Kr}$-corrected ${ }^{87} \mathrm{Sr} /{ }^{86} \mathrm{Sr}$ ratio-a $1 \%$ uncertainty in any or all of the $\mathrm{Kr}$-isotope ratios will change the final corrected ${ }^{87} \mathrm{Sr} /{ }^{86} \mathrm{Sr}$ ratio by $<15 \mathrm{ppm}$. Additionally, allowing the $\mathrm{Kr}$-isotope ratios to fractionate by up to $2 \%$ (before or during entry into the plasma) changes the ${ }^{87} \mathrm{Sr} /{ }^{86} \mathrm{Sr}$ by $<15 \mathrm{ppm}$.

\section{5. $R b$ Correction}

The analysis of basaltic melt inclusions typically involves samples in which 20$50 \%$ of intensity on mass 87 is due to $\mathrm{Rb}$, and large $\mathrm{Rb}$ corrections are required. Our goal was to devise a protocol where the $\mathrm{Rb}$-corrected ${ }^{87} \mathrm{Sr} /{ }^{86} \mathrm{Sr}$ ratios are accurate to within a few hundred ppm. We adopted the strategy of using natural basalt glasses (Table 5) with precisely known ${ }^{87} \mathrm{Sr} /{ }^{86} \mathrm{Sr}$ ratios (obtained by TIMS) to bracket the basalt glass unknowns; for each "standard" glass, the ${ }^{85} \mathrm{Rb} /{ }^{87} \mathrm{Rb}$ ratio required to give the TIMS ${ }^{87} \mathrm{Sr} /{ }^{86} \mathrm{Sr}$ is calculated, and these bracketing ${ }^{85} \mathrm{Rb} /{ }^{87} \mathrm{Rb}$ ratios are then used for the $\mathrm{Rb}$ corrections in the unknown glasses. This method depends only on the $\mathrm{Rb}$ mass bias being relatively invariant on short time scales (20 minutes), and not being a function of the particular major element composition of the various glasses analyzed.

To assess these issues, we performed laser ablation analyses of a suite of 14 Samoan basalt glasses of known ${ }^{87} \mathrm{Sr} /{ }^{86} \mathrm{Sr}$, with significant variability in major and trace element composition. The results of nine one-day analysis campaigns are shown in Fig. 2; interspersed with these laser ablation analyses during the first two days were a series of runs on mixed 984-987 Rb-Sr solutions. While the total variability of the "Required ${ }^{85} \mathrm{Rb} /{ }^{87} \mathrm{Rb}$ " (basically the variability of the $\mathrm{Rb}$ mass bias factor) is substantial (2317 ppm, excluding the 987-984 Rb-Sr solution runs), the variation with time is relatively smooth, such that the bracketing technique will be fairly effective (note that the error on ${ }^{87} \mathrm{Sr}$ due to the $\mathrm{Rb}$ effect is de-magnified by a factor of $\sim 2.59$ due to the ${ }^{85} \mathrm{Rb} /{ }^{87} \mathrm{Rb}$ ratio).

Several things may be noted. First, the "empirically" determined Rb ratio in lasered basalts has an average value of 2.58745 , which is some $2100 \mathrm{ppm}$ lower than the canonical value certified for the SRM984 Rb standard (the stated uncertainty in SRM984 is $\pm 770 \mathrm{ppm}$ ). Whether this reflects the existence of natural isotope variations in $\mathrm{Rb}$, or simply an underestimate of the SRM certified value is unclear. If the former, then it will perhaps be important to use basalt glass standards that are petrogenetically related the unknowns. Secondly, there is a clear tendency for the Rb-Sr solution runs to lie at the high side of the data series, averaging 2.5900 (1200 ppm lower than the canonical value for the SRM984 Rb standard). This would suggest a slight difference in Rb mass bias for solution runs versus laser ablation runs (and this would not be surprising, given the much larger plasma loading from the laser runs).

To assess the overall accuracy of this correction scheme, we have "corrected" each run in two ways: first, using the contiguous bracketing runs, and secondly, correcting each run with the global average "required" ${ }^{85} \mathrm{Rb} /{ }^{87} \mathrm{Rb}$ ratio of 2.58745 . The resulting "corrected" ${ }^{87} \mathrm{Sr} /{ }^{86} \mathrm{Sr}$ ratios are then compared with the known values (note that the internal precision of the solution runs averaged about $\pm 10 \mathrm{ppm}(1 \sigma$, standard error); that of the laser runs averaged $\pm 17 \mathrm{ppm}$, with 88 intensities ranging from 1-12 volts). For the "bracketing technique", the mean deviation (measured against TIMS) for the nine analytical sessions is 127 ppm (320 ppm, $2 \sigma$ standard deviation, assuming a Gaussian distribution); for the "global average" technique, the mean deviation is 155 ppm (Fig. 3). We adopt the first scheme to correct unknowns and when discussing the accuracy of 
standard glass (and melt inclusion) runs; this technique has the advantage of capturing the downward drift of the ${ }^{85} \mathrm{Rb} /{ }^{87} \mathrm{Rb}$ required values over time (see Fig. 2). While obviously not as precise as TIMS analyses, this level of reproducibility is excellent for an in situ technique, and will allow us to embark on a realistic program of melt-inclusion analysis.

Due to the uncertainty of the ${ }^{85} \mathrm{Rb} /{ }^{87} \mathrm{Rb}$ required value, there will be an error magnification on the corrected ${ }^{87} \mathrm{Sr} /{ }^{86} \mathrm{Sr}$ ratios of basaltic unknowns as $\mathrm{Rb} / \mathrm{Sr}$ increases. In order to model this effect, we selected several glass standard runs with different $\mathrm{Rb} / \mathrm{Sr}$ ratios and similar, low $\mathrm{Kr} / \mathrm{Sr}$ ratios, and varied the ${ }^{85} \mathrm{Rb} /{ }^{87} \mathrm{Rb}$ ratio by 2 standard deviations about the mean global value of 2.58745 ( $\pm 0.00278,2 \sigma$ standard deviation). The propagated error increases linearly to $630 \mathrm{ppm}$ when $\mathrm{Rb} / \mathrm{Sr}$ is 0.14 , and the accuracy appears to scale with the $\mathrm{Rb} / \mathrm{Sr}$ such that the uncertainty in ${ }^{85} \mathrm{Rb} /{ }^{87} \mathrm{Rb}$ magnifies the error on the final ${ }^{87} \mathrm{Sr} /{ }^{86} \mathrm{Sr}$ (Fig. 4). However, the "bracketing method" for the Rb correction reduces the uncertainty in the ${ }^{85} \mathrm{Rb} /{ }^{87} \mathrm{Rb}$ required value by $\sim 20 \%$, so that the propagated error from the reduced uncertainty translates to an improvement in the accuracy of the ${ }^{87} \mathrm{Sr} /{ }^{86} \mathrm{Sr}$ r (i.e., to $505 \mathrm{ppm}$ when $\mathrm{Rb} / \mathrm{Sr}$ is 0.14 ). The internal precision for ${ }^{87} \mathrm{Sr} /{ }^{86} \mathrm{Sr}$ measurements on lasered glasses is generally an order of magnitude better than the accuracy (this is also true for the $\mathrm{Rb} / \mathrm{Sr}$ measurements), and does not appear to worsen with increasing $\mathrm{Rb} / \mathrm{Sr}$ ratios. However, the internal precision of the ${ }^{87} \mathrm{Sr} /{ }^{86} \mathrm{Sr}$, but not the accuracy, does vary with Sr intensities (Fig. 5), and, to a lesser extent, the number and length (8 or 16 second integrations) of cycles of analysis. The precision on the melt inclusion analyses also varies as a function of Sr intensity and the number and length of cycles. However, because the accuracy of the ${ }^{87} \mathrm{Sr} /{ }^{86} \mathrm{Sr}$ of Samoan glasses is not related to $\mathrm{Sr}$ intensity over the range of 1-12 Volts on mass 88 (Table 4), somewhat lower $\mathrm{Sr}$ intensities during the melt inclusion runs (1-6.5 Volts) should not affect the overall accuracy of ${ }^{87} \mathrm{Sr} /{ }^{86} \mathrm{Sr}$.

\subsection{Other Interferences}

We have directly measured possible isobaric mass interferences resulting from $\mathrm{Ca}$ dimers and argides, $\mathrm{FeO}_{2}$, doubly-charged $\mathrm{Er}$ and $\mathrm{Yb}$ and $\mathrm{KrH}$. The $\mathrm{Ca}$ dimers and argides invoke errors of less than $<10 \mathrm{ppm}$, for $\mathrm{Ca} / \mathrm{Sr}$ ratios typical of alkali basalts; there is no straightforward way to monitor or correct for these. Similarly, in a typical basalt laser run (with $500 \mathrm{ppm} \mathrm{Sr}$ ), the total propagated error in ${ }^{87} \mathrm{Sr} /{ }^{86} \mathrm{Sr}$ from $\mathrm{FeO}_{2}$ will then be less than $40 \mathrm{ppm}$ (and could be nil). Additionally, the $\mathrm{REE}^{++}$invoke errors of $<30 \mathrm{ppm}$ for typical $\mathrm{Sr} / \mathrm{REE}$ ratios in alkali basalts; these can in principal be corrected for by monitoring the 83.5 and 85.5 half-mass peaks due to ${ }^{167} \mathrm{Er}^{++}$and ${ }^{171} \mathrm{Yb}^{++}$. Finally, there seems to be some evidence for the formation of $\mathrm{KrH}$ in the plasma, with $\mathrm{Kr} / \mathrm{KrH}$ exhibiting ratios from 35-70. Kr hydrides create isobaric interferences on masses 83, 84, 85 and 87 , and they may play an important role when $\mathrm{Kr} / \mathrm{Sr}$ ratios are elevated. In practice, however, it appears that there are frequently other unexplained interferences at these masses, as well as at the $\mathrm{Kr}$ and $\mathrm{Rb}$ masses, so that correction for these isobaric interferences is not always successful. These problems not only limit the attainable precision of laser ablation analyses, but can limit the precision of straightforward $\mathrm{Sr}$ solution analyses as well, even of the SRM987 standard. A continuing investigation of these issues (and a fuller discussion of interferences from $\mathrm{Ca}$ dimers, argides, $\mathrm{FeO}_{2}, \mathrm{KrH}$ and doubly charged Er and $\mathrm{Yb}$ ) is underway (Hart et al., in prep). 


\subsection{Measurement of Rb/Sr by LA-ICP-MS}

Masses 85 and 88 represent pure $\mathrm{Rb}$ and $\mathrm{Sr}$, respectively, so that fairly precise measurement of $\mathrm{Rb} / \mathrm{Sr}$ ratios can be generated. After correcting for mass fractionation during each run, $\mathrm{Rb} / \mathrm{Sr}$ ratios on Samoan basalt glasses measured by laser ablation are accurate to $7 \%$ ( 1 mean deviation, compared to ratios obtained by XRF/ICP techniques on the same glasses), and precise $(0.67 \%, 1$ mean deviation) during multiple runs on a suite of Samoan glasses (Fig. 6). We note that this technique does not appear to work when running a "dry" plasma; $\mathrm{Rb}$ and $\mathrm{Sr}$ are strongly fractionated from each other, so that the measured $\mathrm{Rb} / \mathrm{Sr}$ ratios are up to $80 \%$ higher than in the standard glass (see last 4 analyses in Table 4).

\subsection{Replicability}

We have not yet made a comprehensive study of reproducibility of sample analyses. We have done an analysis of a group of 50 runs on the SRM987 standard, spread over a 17 month time period, using solutions varying in concentration from $10 \mathrm{ppb}$ to $600 \mathrm{ppb}$. All errors discussed here will be given at the $1 \sigma$ level. Considering first the 200 and $600 \mathrm{ppb}$ solutions, the average internal precision for these was $7 \mathrm{ppm}$ (for ${ }^{88} \mathrm{Sr}$ intensities varying from 8-28 volts). The average external precision, calculated from the variations within a single day's analysis session, was $12 \mathrm{ppm}$ (and the number of standards run during each of these sessions varied from 2-6). While the overall ratio of external to internal precision was $\sim 1.8$, there was not a significant correlation between external and internal precision on a session-to-session basis (i.e. the internal precision on individual runs is not a good guide to the expected external precision). For the daily means of 11 sessions over the 17 month time period, the average ${ }^{87} \mathrm{Sr} /{ }^{86} \mathrm{Sr}$ was 0.710255 , with a $1 \sigma$ standard deviation of a single analysis of $15 \mathrm{ppm}$. We should note that this time period involved a number of different baseline protocols and cup configurations, so the statistics may not be representative of our current procedures. There is one obvious conclusion, however, and that is that the precision on a daily basis is similar to the longterm precision; in other words, the variability in standard runs has almost as much "daily" scatter as it does "yearly" scatter.

Within this data set, there is a fair correlation between Sr intensity and the precision of the data; external precision for a given session is $\pm 5 \mathrm{ppm}$ for $>25$ volt data, $\pm 7-20 \mathrm{ppm}$ for $9-15$ volt data and $\pm 50-80 \mathrm{ppm}$ for $0.3-1$ volt data. Overall, the $1 \sigma$ external precision in ppm, as a function of ${ }^{88} \mathrm{Sr}$ intensity in volts, may be empirically expressed as: $\sim\left[80 /(\text { volts })^{0.8}\right]$.

\section{Summary}

The Finnigan NEPTUNE multi-collector ICP-MS has proven to be an excellent instrument for developing robust $\mathrm{Sr}$ isotope analysis protocols. Among its advantages are the stability of the Faraday-amplifier system, the ability to run with intensities up to 50 volts, and the stability of the mass bias for $\mathrm{Sr}$ and $\mathrm{Rb}$. While the external precision of solution analyses are not yet comparable to the best TIMS techniques, the in situ laser ablation technique appears to be a reliable and very promising tool for the study of small scale-length isotopic heterogeneities, even in samples with a significant $\mathrm{Rb}$ component. 


\section{References Cited}

[1] M. Bizzarro, A. Simonetti, R. K. Stevenson, and S. Kurszlaukis, In situ ${ }^{87} \mathrm{Sr} /{ }^{86} \mathrm{Sr}$ investigation of igneous apatites and carbonates using laser-ablation MC-ICP-MS, Geochim. Cosmochim. Acta, 67 (2003) 289-302.

[2] J.N. Christensen, A. N. Halliday, D. C. Lee, and C. M. Hall, In situ isotopic analysis by laser ablation, Earth Planet. Sci. Lett., 136 (1995) 79-85.

[3] J.P Davidson, F. J. Tepley, Z. Palacz and S. Meffan-Main, Magma recharge, contamination and residence times revealed by in situ laser ablation isotopic analysis of feldspar in volcanic rocks, Earth Planet. Sci. Lett., 184 (2001) 427-442.

[4] S.S. Schmidberger, Simonetti, A., and D. Francis, Small-scale Sr isotope investigation of clinopyroxenes from peridotite xenoliths by laser ablation MC-ICP-MSImplications for mantle metasomatism, Chemical Geology, 199 (2003) 317-329.

[5] T. Waight, J. Baker and D. Peate, Sr isotope ratio measurements by double-focusing MC-ICPMS: techniques, observations and pitfalls, International Journal of Mass Spectrometry, 221 (2002) 229-244.

[6] F.C. Ramos, J. A. Wolff and D. L. Tollstrup, Measuring ${ }^{87} \mathrm{Sr} /{ }^{86} \mathrm{Sr}$ variations in minerals and groundmass from basalts using LA-MC-ICPMS, Chemical Geology, 211 (2004) 135-158.

[7] R.K. Workman, S. R. Hart, M. Jackson, M. Regelous, K. A. Farley, J. Blusztajn, M. Kurz, H. Staudigel, Recycled metasomatized lithosphere as the origin of the Enriched Mantle II (EM2) end-member: Evidence from the Samoan volcanic chain, Geochem. Geophys. Geosys. 5 (2004), doi:10.1029/2003GC000623. 


\section{Figure Captions}

Fig. 1. Variation of intensity ratio of mass 82 to mass 83 over time. Series of Samoan basalt glasses analyzed by laser ablation (colored symbols) and mixed $\mathrm{Sr}-\mathrm{Rb}$ standard solutions (SRM987-SRM984, black diamonds). The certificate value for ${ }^{82} \mathrm{Kr} /{ }^{83} \mathrm{Kr}$ is 1.004. We observe no relationship between mass $82 /$ mass 83 and the precision or accuracy of ${ }^{87} \mathrm{Sr} /{ }^{86} \mathrm{Sr}$ measurement by LA-MC-ICPMS.

Fig. 2. ${ }^{85} \mathrm{Rb} /{ }^{87} \mathrm{Rb}$ ratio required to give correct ${ }^{87} \mathrm{Sr} /{ }^{86} \mathrm{Sr}$ of a series of Samoan basalt glasses (analyzed by TIMS, open diamonds) and mixed $\mathrm{Sr}-\mathrm{Rb}$ standard solutions (SRM987-SRM984, filled diamonds). The certificate value for ${ }^{85} \mathrm{Rb} /{ }^{87} \mathrm{Rb}$ in SRM984 is $2.593 \pm 0.002$; all of the "calculated" $\mathrm{Rb}$ ratios are lower than the certificate value, and outside quoted error limits. Runs using a dry plasma not shown.

Fig. 3. Reproducibility of ${ }^{87} \mathrm{Sr} /{ }^{86} \mathrm{Sr}$ for 12 Samoan basalt glass standards (with known $87 \mathrm{Sr} / 86 \mathrm{Sr}$ by TIMS) by LA-MC-ICPMS. Two data trends represent reproducibility (external precision) using the "global average" and the "bracketing" correction schemes for the isobaric interference of $\mathrm{Rb}$ on mass 87 . The bracketing method gives better overall external precision, and is adopted as the correction scheme in the manuscript. Mixed NBS987 and NBS984 solution runs not included in the figure. The downward drift of ${ }^{85} \mathrm{Rb} /{ }^{87} \mathrm{Rb}$ (see Fig. 2) is noted in the downward drift of error using the "global average" Rb correction scheme. Error bars on symbols are internal (in-run) precision (2 mean deviations). Dashed lines mark external precision of \pm 320 ppm $(2 \sigma$, standard deviation). Larger scatter in later runs is due to higher $\mathrm{Rb} / \mathrm{Sr}$ ratios of the glass standards analyzed. Better external precision in early runs is due to smaller variation in ${ }^{85} \mathrm{Rb} /{ }^{87} \mathrm{Rb}$ over time. The glass standard runs at the beginning and the end of each analytical session are not correctible using the bracketing technique and are not plotted. However, all glass standards are correctible using the "global average" Rb correction scheme, so more data points are plotted for this latter correction scheme.

Fig. 4. Rb/Sr vs. propagated error on ${ }^{87} \mathrm{Sr} /{ }^{86} \mathrm{Sr}$ measurement due to uncertainty of the ${ }^{85} \mathrm{Rb} /{ }^{87} \mathrm{Rb}$ required value. The average ${ }^{85} \mathrm{Rb} /{ }^{87} \mathrm{Rb}$ required values (used for correcting the ${ }^{87} \mathrm{Rb}$ isobaric interference on ${ }^{87} \mathrm{Sr}$ ) during all laser runs on Samoan glass standards is $2.58745( \pm 0.00278,2 \sigma)$, and this uncertainty generates larger errors on the final ${ }^{87} \mathrm{Sr} /{ }^{86} \mathrm{Sr}$ at higher $\mathrm{Rb} / \mathrm{Sr}$ ratios. The upper model line shows the error $(2 \sigma$, standard deviation) on final ${ }^{87} \mathrm{Sr} /{ }^{86} \mathrm{Sr}$ ratio when using the "global average" technique for the Rb correction (see text for description). Symbols on line represent error propagation on (from the uncertainty on the ${ }^{85} \mathrm{Rb} /{ }^{87} \mathrm{Rb}$ ) using actual basalt analyses by laser ablation.

Alternatively, error using the "bracketing" method for the Rb correction is $20 \%$ lower, and is described by the lower line. The $\mathrm{Rb}$ correction contributes the vast majority of the error on the final ${ }^{87} \mathrm{Sr} /{ }^{86} \mathrm{Sr}$ in our protocol for measuring basal glasses by LA-MCICPMS. Therefore, we consider the lower model curve to be a good approximation of the reproducibility of our method. 
Fig. 5. Relationship between intensity on mass 88 and internal precision during laser ablation analysis of Samoan glass standards. Various Neptune and laser operating conditions and variations in basalt and plasma chemistry, inclusing $\mathrm{Rb} / \mathrm{Sr}$ and $\mathrm{Kr} / \mathrm{Sr}$, show little or no relationship with measurement precision. The curve models the relationship between intensity and internal precision ( 1 mean deviation), and is described by the following relationship: Precision $=45 *(\sqrt{ }$ Intensity $) /$ Intensity.

Fig. 6. Samoan glass Rb/Sr measured by LA-MC-ICPMS Neptune plotted against Rb/Sr measured by standard techniques (XRF or ICP) on powders of the same glasses. Error bars ( $2 \sigma$ standard deviation from the mean of measured values) are shown on samples with at least 9 laser analyses. All other glasses had one or two analyses. One-to-one line is solid, and weighted least squares regression (including equation) is dashed. 
Table 1. Typical NEPTUNE and Laser Operating Parameters

\section{RF Power}

Argon cooling gas, flow rate

Ar auxiliary gas, flow rate

He sample gas, flow rate

Interface cones

Mass analyzer pressure

Resolution mode

Abundance sensitivity

Detection system

Signal analysis set-up

Background-baseline protocol

Nebuliser and uptake rate

Spray chamber

Sensitivity, solution $\mathrm{Sr}$

Sensitivity, laser $\mathrm{Sr}$

Laser type

Carrier gas

Beam optics

Spot size

Raster pattern

Pulse rate

Power setting

Power delivered

Pre-ablation
$1200 \mathrm{~W}$

$15 \mathrm{~L} / \mathrm{min}$

$0.8 \mathrm{~L} / \mathrm{min}$

$0.5 \mathrm{~L} / \mathrm{min}$

$\mathrm{X}$-cones

$5 \times 10^{-9} \mathrm{mbar}$

Low (400)

$\sim 1$ ppm at -1 amu, mass 88 (RPQ off)

Faraday cups (9)

$8 \mathrm{sec}$ or $16 \mathrm{sec}$ integration/cycle, 40 or 20 cycles

1 min integration pre-analysis, -0.7 amu all Faradays

Elemental Scientific, Inc., PFA 20-50 microliters per minute

Elemental Scientific, Inc., Stable Introduction System (SIS)

$75 \mathrm{~V}^{88} \mathrm{Sr}$ per ppm $\mathrm{Sr}$ in $5 \% \mathrm{HNO}_{3}$

$\sim 1$ volt ${ }^{88} \mathrm{Sr}$ per $100 \mathrm{ppm} \mathrm{Sr}$ in basalt at $1 \mathrm{mj}$

New Wave UP213, quad Nd YAG $213 \mathrm{~nm}$

Helium

Apertured mode

120 um (60 um or less in high-Sr carbonates)

200 x $200 \mathrm{um}, 20 \mathrm{um}$ line spacing, $4 \mathrm{um} / \mathrm{sec}$

$20 \mathrm{~Hz}$

$100 \%$ (lower for high-Sr carbonates)

$\sim 1.0-1.3 \mathrm{mj}$

same raster and spot size, $5 \mathrm{~Hz}, 45 \%$ power, $30 \mathrm{um} / \mathrm{sec}$ 


\begin{tabular}{|cc|}
\hline \multicolumn{2}{|c|}{ Table 2. Faraday Cup Configuration } \\
Laser Ablation Sr Isotope Analysis \\
\hline Cup & $\frac{\text { Mass }}{88}$ \\
H4 & 87 \\
H3 & 86 \\
H2 & 85 \\
H1 & 84 \\
C & 83 \\
L1 & 82.5 \\
L2 & 82 \\
L3 & 81.5 \\
L4 & \\
&
\end{tabular}


Table 3. Adopted Isotopic Abundances.

\begin{tabular}{cc} 
Krypton & Isotopic Abunance \\
\cline { 1 - 1 } 78 & 0.003469 \\
80 & 0.02257 \\
82 & 0.11523 \\
83 & 0.11477 \\
84 & 0.56998 \\
86 & 0.17398
\end{tabular}

From Ozima and Podosek, 2001

$\underline{\text { Strontium SRM987 Isotopic Abundance }}$ I* Isotopic Abundance*

$\begin{array}{lll}84 & 0.005578 & 0.005574 \\ 86 & 0.098600 & 0.098566 \\ 87 & 0.070029 & 0.070015 \\ 88 & 0.825793 & 0.825845\end{array}$

\begin{tabular}{|c|c|c|c|c|}
\hline & Isotopic Ratios** & Isotopic Ratios* & & \\
\hline $84 / 86$ & 0.056573 & 0.056549 & \pm 2529 & ppm \\
\hline $87 / 86$ & 0.710194 & 0.710339 & \pm 367 & ppm \\
\hline $88 / 86$ & 8.375209 & 8.37861 & \pm 388 & ppm \\
\hline $84 / 88$ & 0.006755 & 0.006749 & \pm 2529 & ppm \\
\hline $86 / 88$ & 0.119400 & 0.119352 & \pm 388 & ppm \\
\hline
\end{tabular}

${ }^{*}$ NIST Certificate Values for SRM987 with quoted uncertainties.

** Renormalized to 0.1194 using exponential law; this value has been used by community consensus for decades. The corresponding ${ }^{87} \mathrm{Sr} /{ }^{86} \mathrm{Sr}$ value adopted by most of the community is $\mathbf{0 . 7 1 0 2 4}$.

$\underline{\text { Rubidium SRM984 }}$

$\begin{array}{cccc}85 & 0.72168 & & \\ 87 & 0.27832 & & \\ 85 / 87^{*} & 2.593 \quad \pm 771 & \text { ppm }\end{array}$

*NIST Certificate Values for SRM984, with quoted uncertainties. 


\section{Table 4. Corrected and normalized ${ }^{87} \mathrm{Sr}{ }^{86} \mathrm{Sr}$ glass standard data, including $\mathrm{Rb} / \mathrm{Sr}$ ratios and raw exported Neptune data (in Volts) on masses 82 to 88}

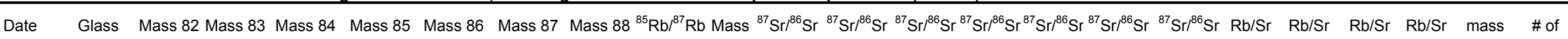

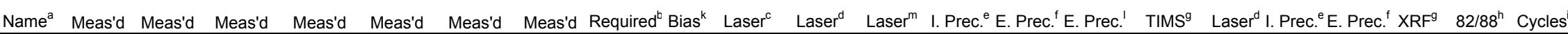

\begin{tabular}{|c|c|c|c|c|c|c|c|c|c|c|c|c|c|c|c|c|c|c|c|c|c|}
\hline 01/26/04 75-10 & .0019 & 0015 & 0.070160 & 0.3830761 .161550 & 0.981164 & 9.99332 & 2.58799 & 1.45 & 0.70451 & 0.70450 & -- & 10 & 41 & -- & 0.704533 & 0.041 & 1.18 & 8.4 & 0.045 & 0.00019 & 20 \\
\hline $1 / 26 / 04 \quad 75-10$ & 0.0019 & 0015 & 68130 & 109051.130253 & 0.970173 & 9.72817 & 2.58762 & 1.47 & 0.70452 & 0.70452 & 0.70454 & 11 & 19 & 12 & 0.704533 & 0.045 & 0.42 & 0.9 & 0.045 & .00020 & 20 \\
\hline $1 / 26 / 04 \quad 75-10$ & 0.0019 & 0.0015 & 0.056972 & 0.3165600 .928578 & 0.788522 & 7.99055 & 2.58761 & 1.48 & 0.70452 & 0.70452 & 0.70456 & 10 & 16 & 39 & 0.704533 & 0.042 & 0.97 & 5.4 & 0.045 & 0.00023 & 20 \\
\hline $1 / 26 / 04 \quad 75-10$ & 0.0018 & 0.0014 & 0.038589 & 0.2106800 .591571 & 0.505435 & 5.08531 & 2.58867 & 1.49 & 0.70447 & 0.70446 & 0.70450 & 11 & 97 & 41 & 0.704533 & 0.044 & 1.00 & 1.1 & 0.045 & 0.00035 & 20 \\
\hline 01/26/04 75-10 & 0.0019 & 0.0015 & 0.059566 & 0.3105590 .978671 & 0.821938 & 8.42300 & 2.58865 & 1.48 & 0.70448 & 0.70447 & 0.70456 & 9 & 85 & 34 & 0.704533 & 0.039 & 3.32 & 12.0 & 0.045 & 0.00022 & 20 \\
\hline $1 / 26 / 04 \quad 76-13$ & 0.0017 & 0.0014 & 0.055907 & 0.5444590 .915110 & 0.871425 & 7.87805 & 2.58963 & 1.50 & 0.70620 & 0.70619 & 0.70633 & 13 & 285 & 89 & 0.706395 & 0.074 & 0.30 & 4.5 & 0.077 & 0.00022 & 20 \\
\hline $1 / 26 / 04 \quad 76-8$ & 0.0017 & 0.0014 & 0.054455 & 0.5263630 .889211 & 0.845639 & 7.65417 & 2.58922 & 1.49 & 0.70621 & 0.70621 & 0.70639 & 11 & 231 & 22 & 0.706374 & 0.073 & 0.16 & 9.8 & 0.081 & 0.00023 & 20 \\
\hline 1/26/04 63-13 & 0.0017 & 0.0013 & 0.045648 & 0.4413950 .731734 & 0.698360 & 6.29660 & 2.58914 & 1.50 & 0.70536 & 0.70536 & 0.70547 & 11 & 226 & 71 & 0.705520 & 0.075 & 0.90 & 4.7 & 0.071 & 0.00028 & 20 \\
\hline $1 / 26 / 04 \quad 68-3$ & 0.0018 & 0.0013 & 0.045375 & 0.3737550 .727534 & 0.668448 & 6.26096 & 2.58796 & 1.50 & 0.70535 & 0.70534 & 0.70542 & 15 & 62 & 51 & 0.705388 & 0.064 & 0.60 & 7.3 & 0.069 & 0.00029 & 20 \\
\hline $1 / 26 / 04 \quad 72-2$ & 0.0019 & 0.0013 & 0.048745 & $0.436044 \quad 0.789158$ & 0.737371 & 6.79224 & 2.58771 & 1.50 & 0.70537 & 0.70537 & 0.70538 & 19 & 37 & 16 & 0.705395 & 0.069 & 0.37 & 15.1 & 0.060 & 0.00028 & 20 \\
\hline 1/26/04 73-12 & 0.0019 & 0.0013 & 0.045637 & 0.4508650 .733196 & 0.704204 & 6.30990 & 2.58719 & 1.50 & 0.70668 & 0.70667 & 0.70670 & 14 & 28 & 63 & 0.706653 & 0.076 & 0.58 & 0.1 & 0.076 & 0.00030 & 18 \\
\hline $1 / 26 / 04 \quad 71-2$ & 0.0019 & 0.0013 & 0.045247 & 0.4121290 .726657 & 0.683560 & 6.25381 & 2.58762 & 1.50 & 0.70593 & 0.70592 & 0.70597 & 14 & 27 & 37 & 0.705943 & 0.070 & 0.22 & 6.8 & 0.075 & 0.00030 & 20 \\
\hline $1 / 26 / 04 \quad 73-1$ & 0.0018 & 0.0013 & 0.050270 & 0.5332920 .818134 & 0.797957 & 7.04356 & 2.58866 & 1.51 & 0.70660 & 0.70660 & 0.70666 & 10 & 175 & 86 & 0.706720 & 0.081 & 0.49 & 0.3 & 0.081 & 0.00026 & 20 \\
\hline $1 / 26 / 04 \quad 70-1$ & 0.0016 & 0.0010 & 0.035357 & 0.2701990 .577103 & 0.519443 & 4.96111 & 2.58846 & 1.43 & 0.70530 & 0.70530 & 0.70540 & 14 & 107 & 41 & 0.705371 & 0.058 & 0.70 & 2.1 & 0.060 & 0.00033 & 20 \\
\hline 1/26/04 71-11 & 0.0016 & 0.0010 & 0.036493 & 0.3164050 .590123 & 0.547012 & 5.07213 & 2.58908 & 1.43 & 0.70526 & 0.70526 & 0.70537 & 12 & 194 & 27 & 0.705394 & 0.067 & 0.27 & 4.7 & 0.070 & 0.00031 & 20 \\
\hline 1/26/04 71-22 & 0.0017 & 0.0013 & 0.041431 & 0.3621450 .673708 & 0.625087 & 5.79313 & 2.58923 & 1.44 & 0.70533 & 0.70532 & -- & 14 & 211 & -- & 0.705473 & 0.067 & 0.55 & 6.1 & 0.071 & 0.00029 & 20 \\
\hline $1 / 27 / 04 \quad 73-1$ & 0.0015 & 0.0010 & 0.042357 & 0.5014910 .715500 & 0.713457 & 6.18177 & 2.58963 & 1.65 & 0.70655 & 0.70648 & -- & 14 & 336 & -- & 0.706720 & 0.086 & 0.54 & 7.0 & 0.081 & 0.00024 & 20 \\
\hline 1/27/04 76-13 & 0.0012 & 0.0009 & 0.041502 & 0.4270550 .703095 & 0.674792 & 6.07676 & 2.58938 & 1.67 & 0.70628 & 0.70621 & 0.70641 & 14 & 259 & 25 & 0.706395 & 0.075 & 0.45 & 3.4 & 0.077 & 0.00020 & 17 \\
\hline $1 / 27 / 04 \quad 63-13$ & 0.0011 & 0.0009 & 0.035692 & 0.3557030 .599686 & 0.571649 & 5.18396 & 2.58951 & 1.69 & 0.70539 & 0.70533 & 0.70553 & 17 & 270 & 8 & 0.705520 & 0.073 & 1.43 & 1.8 & 0.071 & 0.00021 & 20 \\
\hline $1 / 27 / 04 \quad 78-1$ & 0.0011 & 0.0008 & 0.041195 & 0.6393970 .702572 & 0.761301 & 6.07662 & 2.58977 & 1.70 & 0.70862 & 0.70856 & 0.70875 & 16 & 462 & 185 & 0.708886 & 0.112 & 1.26 & 11.1 & 0.126 & 0.00018 & 20 \\
\hline $1 / 27 / 04 \quad 75-10$ & 0.0011 & 0.0008 & 0.042356 & 0.2807780 .725189 & 0.631261 & 6.27295 & 2.58813 & 1.70 & 0.70455 & 0.70449 & 0.70463 & 12 & 61 & 137 & 0.704533 & 0.047 & 0.41 & 6.1 & 0.045 & 0.00017 & 20 \\
\hline $1 / 27 / 04 \quad 76-13$ & 0.0016 & 0.0013 & 0.055752 & 0.5525200 .923794 & 0.881225 & 7.95726 & 2.58977 & 1.51 & 0.70624 & 0.70618 & 0.70632 & 12 & 304 & 111 & 0.706395 & 0.074 & 0.27 & 4.1 & 0.077 & 0.00020 & 10 \\
\hline 1/27/04 76-13 & 0.0016 & 0.0013 & 0.055497 & 0.5546830 .920418 & 0.879848 & 7.93062 & 2.58968 & 1.53 & 0.70625 & 0.70619 & 0.70641 & 10 & 295 & 17 & 0.706395 & 0.075 & 0.26 & 3.5 & 0.077 & 0.00020 & 20 \\
\hline 1/27/04 76-13 & .0016 & 0.0013 & 0.058108 & 0.5786870 .970494 & 0.925562 & 8.36646 & 2.58986 & 1.55 & 0.70624 & 0.70617 & 0.70638 & 11 & 315 & 24 & 0.706395 & 0.074 & 0.41 & 0.8 & 0.077 & 0.00019 & 20 \\
\hline $1 / 27 / 0476-$ & 0015 & 0.0013 & 800 & 70.8 & 391 & 391 & 58966 & 1.54 & 0.70625 & 0.70618 & -- & 12 & 301 & -- & 0.706395 & 0.077 & 0.42 & 4.6 & 0.077 & 0.00022 & 20 \\
\hline 471 & 0.0020 & 0.0020 & 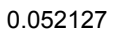 & 0. & 59 & 3 & 58794 & 1.41 & 542 & 5 & -- & 1 & 62 & -- & 94 & 0.065 & 0.2 & 6.5 & 0.070 & 30 & 4 \\
\hline 2/13/04 78-8 & $00 ?$ & 0.0019 & 67 & 720.740226 & 02 & 140 & 3835 & 1.42 & 757 & 50 & -- & 13 & 159 & -- & 14 & 0.098 & .40 & 0.5 & .097 & 32 & 0 \\
\hline $3 / 26 / 04 \quad 70-1$ & 0019 & 16 & 911 & 6740.7 & 3370 & 6.06027 & 3680 & 1.56 & 0545 & 0541 & -- & 17 & 60 & -- & 5371 & 0.058 & 0.27 & 3.2 & .060 & 032 & 20 \\
\hline $12 / 09 / 04 \quad 75-10$ & 0.0027 & 0.0026 & 0.062513 & 0.3211990 .902189 & 0.770682 & 7.75525 & 2.58656 & 1.56 & 0.70465 & 0.70458 & -- & 9 & 64 & -- & 704533 & 0.044 & 0.34 & 1.4 & 0.045 & 0.00035 & 19 \\
\hline $12 / 09 / 04 \quad 75-10$ & 0.0025 & 0.0025 & 0.062778 & 0.3274320 .917974 & 0.785039 & 7.90096 & 2.58672 & 1.61 & 0.70464 & 0.70457 & 0.70459 & 10 & 52 & 82 & 0.704533 & 0.044 & 0.17 & 1.5 & 0.045 & 0.00032 & 48 \\
\hline $12 / 09 / 04 \quad 76-13$ & 0.0025 & 0.0024 & 0.063843 & 0.5576620 .950939 & 0.902924 & 8.19690 & 2.58901 & 1.67 & 0.70632 & 0.70625 & 0.70629 & 10 & 203 & 144 & 0.706395 & 0.072 & 0.13 & 6.5 & 0.077 & 0.00030 & 49 \\
\hline
\end{tabular}




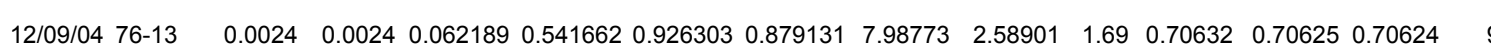
$12 / 09 / 0475-10$ 12/09/04 75-10 01/10/05 76-13 01/10/05 76-13 01/10/05 71-2 01/10/05 71-2 01/10/05 76-13 01/10/05 71-2 01/10/05 71-2 $01 / 10 / 0571-2$ 01/10/05 76-13 01/10/05 76-13 01/10/05 76-13 01/10/05 71-2 01/11/05 71-2 01/11/05 71-2 01/11/05 71-2 01/11/05 76-13 $01 / 11 / 0576-13$ 01/11/05 76-13 01/11/05 71-2 $01 / 11 / 0576-13$ 01/11/05 71-2 01/11/05 71-2 $01 / 11 / 0576-13$ 01/11/05 76-13 01/11/05 71-2 $01 / 11 / 0571-2$ 01/11/05 71-2 01/11/05 71-2 01/11/05 71-2 01/11/05 71-2 08/09/05 71-2

$\begin{array}{llllllllllll}0.0021 & 0.0022 & 0.041088 & 0.190853 & 0.563339 & 0.478042 & 4.85665 & 2.58560 & 1.77 & 0.70469 & 0.70463 & 0.70466\end{array}$ $\begin{array}{lllllllllll}0.0020 & 0.0019 & 0.044719 & 0.210583 & 0.648179 & 0.547229 & 5.59980 & 2.58695 & 1.82 & 0.70462 & 0.70456\end{array}$ $\begin{array}{lllllllllll}0.0029 & 0.0032 & 0.062592 & 0.558316 & 0.908212 & 0.873053 & 7.83316 & 2.58638 & 1.73 & 0.70650 & 0.70649\end{array}$

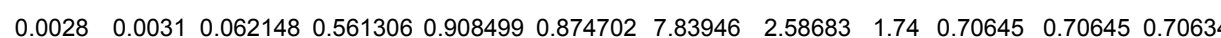
$\begin{array}{llllllllllll}0.0033 & 0.0035 & 0.045848 & 0.326355 & 0.560609 & 0.529545 & 4.81303 & 2.58615 & 1.70 & 0.70606 & 0.70605 & 0.70601\end{array}$ $\begin{array}{llllllllllll}0.0035 & 0.0038 & 0.053988 & 0.403808 & 0.691899 & 0.654374 & 5.94536 & 2.58697 & 1.69 & 0.70599 & 0.70598 & 0.70585\end{array}$ $\begin{array}{llllllllllll}0.0036 & 0.0044 & 0.065799 & 0.643348 & 0.910299 & 0.907215 & 7.83305 & 2.58571 & 1.66 & 0.70658 & 0.70658 & 0.70655\end{array}$

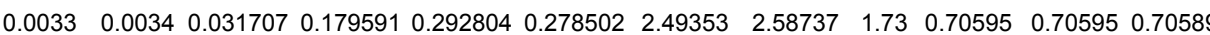
$\begin{array}{llllllllllll}0.0019 & 0.0019 & 0.019831 & 0.129680 & 0.205503 & 0.197576 & 1.75832 & 2.58781 & 1.78 & 0.70591 & 0.70590 & 0.70600\end{array}$ $\begin{array}{llllllllllll}0.0019 & 0.0020 & 0.018789 & 0.111868 & 0.176592 & 0.169506 & 1.50584 & 2.58933 & 1.77 & 0.70576 & 0.70575 & 0.70575\end{array}$

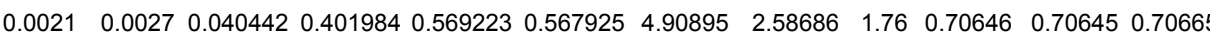

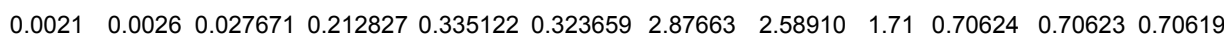

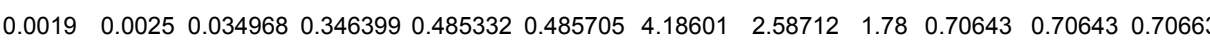

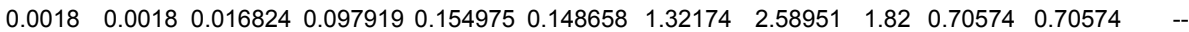
$\begin{array}{llllllllllll}0.0046 & 0.0051 & 0.069247 & 0.570788 & 0.881891 & 0.852357 & 7.52080 & 2.58694 & 1.29 & 0.70599 & 0.70596 & --\end{array}$

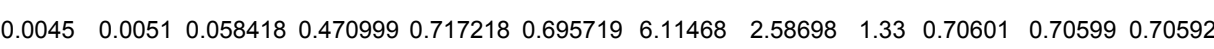

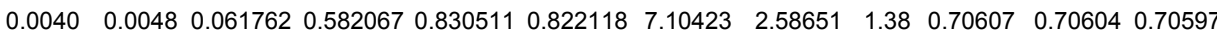

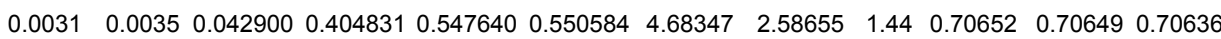
$\begin{array}{llllllllllll}0.0034 & 0.0041 & 0.054000 & 0.586498 & 0.753766 & 0.770557 & 6.45857 & 2.58594 & 1.43 & 0.70659 & 0.70657 & 0.70643\end{array}$

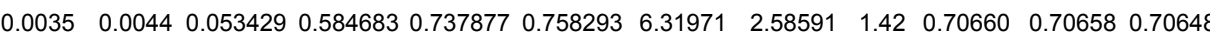

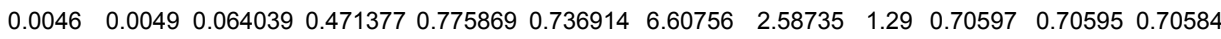
$\begin{array}{llllllllllll}0.0049 & 0.0053 & 0.064899 & 0.528307 & 0.775994 & 0.759615 & 6.60372 & 2.58653 & 1.27 & 0.70651 & 0.70649 & 0.70650\end{array}$

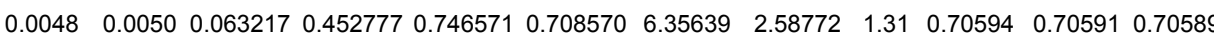

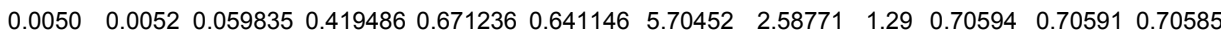
$\begin{array}{llllllllllll}0.0052 & 0.0066 & 0.099696 & 1.041701 & 1.410914 & 1.417626 & 12.0573 & 2.58577 & 1.27 & 0.70661 & 0.70658 & 0.70649\end{array}$

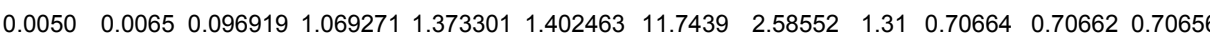

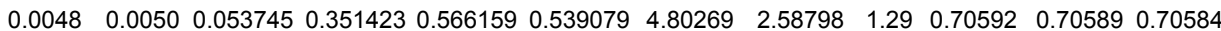

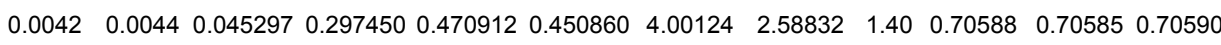

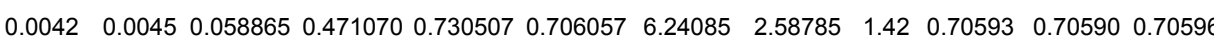

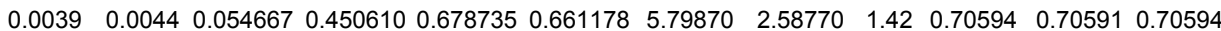

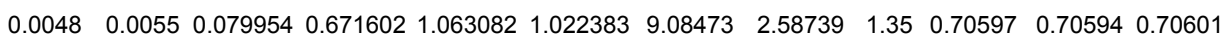
$\begin{array}{lllllllllllll}0.0047 & 0.0050 & 0.052864 & 0.347356 & 0.566080 & 0.537973 & 4.80994 & 2.58846 & 1.35 & 0.70587 & 0.70584 & -\end{array}$ $\begin{array}{lllllllllll}0.0014 & 0.0011 & 0.022728 & 0.258610 & 0.388432 & 0.379989 & 3.33312 & 2.58724 & 1.28 & 0.70596 & 0.70596\end{array}$

203
133
32
136
76
158
54
258
5
56
268
83
233
44
291
26
60
135
135
245
255
7
128
43
42
260
315
78
126
63
43
1
141
23

\begin{tabular}{|c|c|c|c|c|c|c|}
\hline 15 & 0.706395 & 0.072 & 0.13 & 6.9 & 0.077 & 0.00030 \\
\hline & 0.704533 & 0.042 & 1.64 & 7.0 & 0.045 & 0.00043 \\
\hline & 0.704533 & 0.040 & 2.09 & 11.2 & 0.045 & 0.00035 \\
\hline - & 0.706395 & 0.076 & 0.17 & 2.2 & 0.077 & 0.00037 \\
\hline 76 & 0.706395 & 0.076 & 0.19 & 1.8 & 0.077 & 0.00036 \\
\hline 95 & 0.705943 & 0.072 & 0.24 & 4.7 & 0.075 & 0.00069 \\
\hline 132 & 0.705943 & 0.072 & 0.30 & 4.5 & 0.075 & 0.00059 \\
\hline 223 & 0.706395 & 0.087 & 0.36 & 12.9 & 0.077 & 0.00046 \\
\hline 31 & 0.705943 & 0.076 & 0.51 & 1.2 & 0.075 & 0.00133 \\
\hline 75 & 0.705943 & 0.078 & 0.34 & 3.4 & 0.075 & 0.00106 \\
\hline 278 & 0.705943 & 0.079 & 0.68 & 4.2 & 0.075 & 0.00129 \\
\hline 360 & 0.706395 & 0.087 & 0.38 & 12.2 & 0.077 & 0.00043 \\
\hline 90 & 0.706395 & 0.078 & 0.98 & 1.5 & 0.077 & 0.00073 \\
\hline 38 & 0.706395 & 0.088 & 0.30 & 13.3 & 0.077 & 0.00046 \\
\hline - & 0.705943 & 0.078 & 0.84 & 3.8 & 0.075 & 0.00133 \\
\hline -- & 0.705943 & 0.082 & 0.66 & 8.1 & 0.075 & 0.00061 \\
\hline 36 & 0.705943 & 0.083 & 0.58 & 9.6 & 0.075 & 0.00073 \\
\hline 39 & 0.705943 & 0.088 & 0.63 & 16.3 & 0.075 & 0.00056 \\
\hline 53 & 0.706395 & 0.092 & 0.65 & 19.6 & 0.077 & 0.00066 \\
\hline 48 & 0.706395 & 0.097 & 0.66 & 25.8 & 0.077 & 0.00052 \\
\hline 126 & 0.706395 & 0.099 & 0.47 & 28.2 & 0.077 & 0.00055 \\
\hline 140 & 0.705943 & 0.077 & 0.54 & 1.6 & 0.075 & 0.00070 \\
\hline 148 & 0.706395 & 0.086 & 0.60 & 11.3 & 0.077 & 0.00074 \\
\hline 79 & 0.705943 & 0.076 & 0.49 & 1.4 & 0.075 & 0.00075 \\
\hline 121 & 0.705943 & 0.079 & 0.47 & 4.7 & 0.075 & 0.00087 \\
\hline & 0.706395 & 0.093 & 0.23 & 20.2 & 0.077 & 0.00043 \\
\hline 227 & 0.706395 & 0.098 & 0.46 & 26.6 & 0.077 & 0.00043 \\
\hline 112 & 0.705943 & 0.079 & 0.39 & 4.2 & 0.075 & 0.00101 \\
\hline 55 & 0.705943 & 0.080 & 0.71 & 5.5 & 0.075 & 0.00106 \\
\hline กา & 0.705943 & 0.081 & 0.58 & 7.0 & 0.075 & 0.00067 \\
\hline 11 & 0.705943 & 0.083 & 0.24 & 10.2 & 0.075 & 0.00067 \\
\hline 94 & 0.705943 & 0.079 & 0.35 & 5.1 & 0.075 & 0.00053 \\
\hline & 0.705943 & 0.077 & 0.89 & 2.6 & 0.075 & 0.00098 \\
\hline & 0.705943 & 0.083 & 1.38 & 10.5 & 0.07 & 0.00041 \\
\hline
\end{tabular}


08/09/05 71-2 08/09/05 75-10 08/09/05 71-2 08/09/05 75-10 08/09/05 76-13 08/09/05 76-13 08/09/05 71-2 08/09/05 75-10 08/10/05 71-2 08/10/05 75-10 08/10/05 76-13 08/10/05 71-2 08/10/05 75-10 08/10/05 71-2 08/10/05 76-13 08/11/05 71-2 08/11/05 71-2 08/11/05 71-2 08/11/05 71-2 08/11/05 71-2 08/11/05 71-2 08/11/05 71-2 08/11/05 71-2 08/11/05 71-2 01/16/06 78-1 01/16/06 78-1 01/16/06 78-1 01/16/06 78-1 01/16/06 78-1 01/16/06 78-1 01/16/06 78-1 01/16/06 78-1 01/16/06 71-2 01/16/06 71-2i

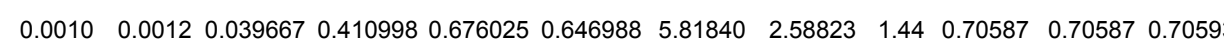

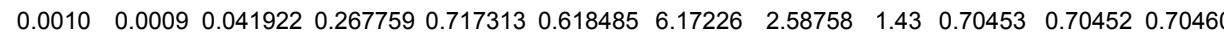

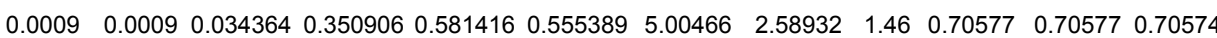
$\begin{array}{llllllllllll}0.0010 & 0.0012 & 0.044398 & 0.305593 & 0.761972 & 0.665350 & 6.55471 & 2.58663 & 1.41 & 0.70458 & 0.70458 & 0.70468\end{array}$

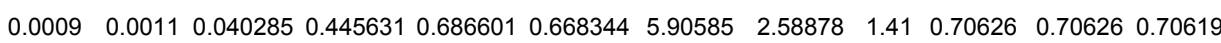
$\begin{array}{llllllllllll}0.0011 & 0.0021 & 0.058298 & 0.720332 & 1.014084 & 1.011925 & 8.72086 & 2.58676 & 1.38 & 0.70647 & 0.70646 & 0.70663\end{array}$

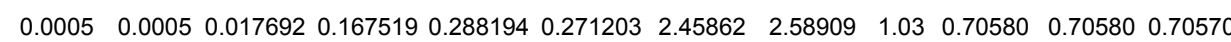
$\begin{array}{lllllllllllll}0.0006 & 0.0008 & 0.029739 & 0.191258 & 0.502920 & 0.433086 & 4.29411 & 2.58584 & 1.03 & 0.70463 & 0.70462 & --\end{array}$ $\begin{array}{llllllllllll}0.0008 & 0.0008 & 0.030262 & 0.298953 & 0.507454 & 0.483010 & 4.38372 & 2.58702 & 1.65 & 0.70598 & 0.70598 & -\end{array}$ $\begin{array}{llllllllllll}0.0008 & 0.0010 & 0.038555 & 0.249734 & 0.660744 & 0.572473 & 5.70962 & 2.58474 & 1.65 & 0.70469 & 0.70469 & 0.70462\end{array}$

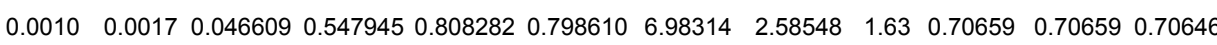

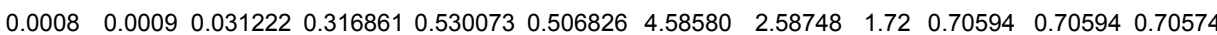

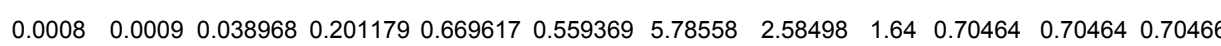

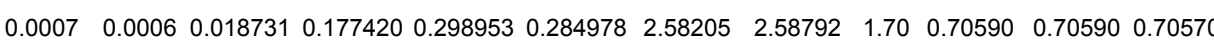

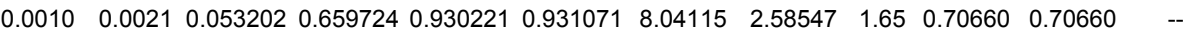
$\begin{array}{llllllllllll}0.0008 & 0.0008 & 0.028474 & 0.280326 & 0.481040 & 0.457445 & 4.16744 & 2.58755 & 1.80 & 0.70593 & 0.70593 & -\end{array}$ $\begin{array}{llllllllllll}0.0008 & 0.0009 & 0.025628 & 0.249742 & 0.428075 & 0.407073 & 3.70673 & 2.58701 & 1.78 & 0.70598 & 0.70598 & 0.70597\end{array}$

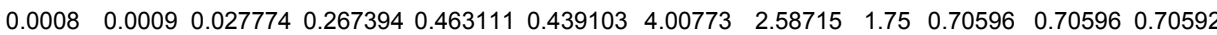
$\begin{array}{llllllllllll}0.0006 & 0.0008 & 0.025284 & 0.255547 & 0.433576 & 0.413754 & 3.75980 & 2.58677 & 1.83 & 0.70600 & 0.70600 & 0.70597\end{array}$ $\begin{array}{llllllllllll}0.0007 & 0.0008 & 0.026528 & 0.274040 & 0.455528 & 0.436904 & 3.94988 & 2.58697 & 1.83 & 0.70598 & 0.70598 & 0.70597\end{array}$

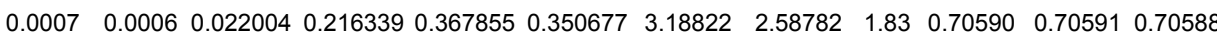

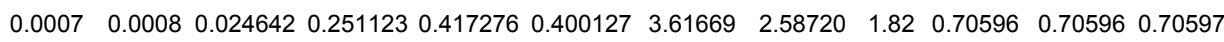

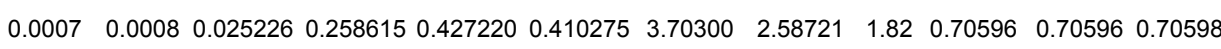
$\begin{array}{llllllllllll}0.0007 & 0.0007 & 0.023358 & 0.232289 & 0.395225 & 0.376807 & 3.42680 & 2.58804 & 1.84 & 0.70589 & 0.70589 & \ldots\end{array}$ $\begin{array}{llllllllllll}0.0062 & 0.0061 & 0.070911 & 0.689532 & 0.762508 & 0.818940 & 6.52057 & 2.58430 & 1.69 & 0.70947 & 0.70932 & \ldots\end{array}$ $\begin{array}{llllllllllll}0.0059 & 0.0058 & 0.050415 & 0.365045 & 0.405995 & 0.432392 & 3.43846 & 2.58490 & 1.72 & 0.70939 & 0.70924 & 0.7089\end{array}$

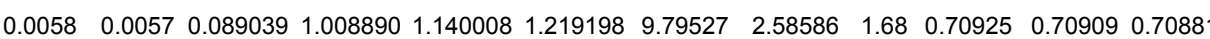

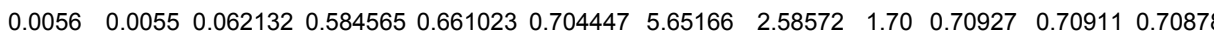

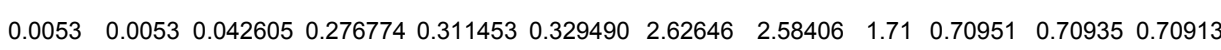

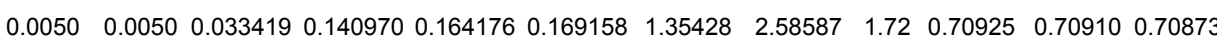

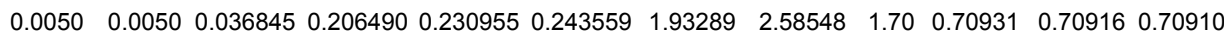
$\begin{array}{llllllllllll}0.0085 & 0.0085 & 0.049816 & 0.121730 & 0.146879 & 0.145002 & 1.15711 & 2.58816 & 1.77 & 0.70894 & 0.70878 & 0.70854\end{array}$

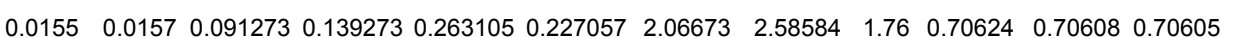
$\begin{array}{llllllllllll}0.0183 & 0.0185 & 0.123513 & 0.333251 & 0.611060 & 0.551464 & 5.04318 & 2.58586 & 1.72 & 0.70623 & 0.70608 & \ldots\end{array}$

24




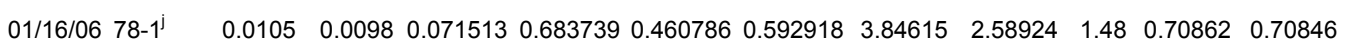

$\begin{array}{lllllllllllll}01 / 16 / 06 & 78-1^{j} & 0.0111 & 0.0104 & 0.090872 & 1.314651 & 0.775036 & 1.069266 & 6.54519 & 2.58742 & 1.44 & 0.70904 & 0.70888\end{array}$

$\begin{array}{lllllllllllll}01 / 16 / 06 & 71-2^{\mathrm{j}} & 0.0119 & 0.0112 & 0.086823 & 0.653507 & 0.631526 & 0.700407 & 5.29883 & 2.58759 & 1.45 & 0.70607 & 0.70591\end{array}$

$-\quad 37$

602

$-\quad 24$

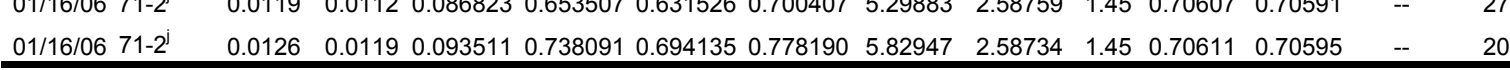

Analyses are listed in chronological order. Cycles are 16 second integrations of measurement during analysis until 3/26/04. Cycles are 8 second integrations thereafter.

${ }^{a}$ All samples are dredge samples from the AVON3 dredging cruise (Workman et al., 2004) [7]

${ }^{\mathrm{b}}{ }^{85} \mathrm{Rb} /{ }^{87} \mathrm{Rb}$ required values are obtained after correcting for $\mathrm{Kr}$ and $\mathrm{Rb}$ interferences, fractionation correction, and normalization to NBS 987 solution run:

during each analytical session. The average ${ }^{85} \mathrm{Rb} /{ }^{87} \mathrm{Rb}$ required value is 2.58745 , which is used to obtain the $\mathrm{Rb}$ correction using the "global average" technique

${ }^{\mathrm{c}} \mathrm{Sr}$-isotopes are corrected for $\mathrm{Kr}$ and $\mathrm{Rb}$ interferences and fractionation corrected

${ }^{\mathrm{d}}$ After correction for $\mathrm{Rb}$ and $\mathrm{Sr}$ interferences and fractionation, glass standard runs are corrected for 987 standard solution runs for each analytical sessior

${ }^{\mathrm{e}}$ Internal (in-run) precision (I. Prec.) is quoted as $1 \sigma$ standard error, and is calculated offline using the TweaKr program. In the above dataset, the average internal precision is $17 \mathrm{ppm}$ for ${ }^{87} \mathrm{Sr}^{86} \mathrm{Sr}$, and $0.67 \%$ for $\mathrm{Rb} / \mathrm{Sr}$.

${ }^{\mathrm{f}}$ External precision (E. Prec.) is calculated assuming that the $\mathrm{TIMS}{ }^{87} \mathrm{Sr} /{ }^{86} \mathrm{Sr}(\mathrm{ppm})$ and $\mathrm{XRF} \mathrm{Rb} / \mathrm{Sr}(\%)$ values obtained on bulk powders are correct. The average external precision of ${ }^{87} \mathrm{Sr} /{ }^{86} \mathrm{Sr}$ measurements

on the above glass standards is $155 \mathrm{ppm}$ mean deviation (1 $\sigma)$, which translates to $388 \mathrm{ppm}$ standard deviation $(2 \sigma)$ if a Gaussian distribution is assumed. The average external precision on Rb/Sr

measurements on glass standards is $6.7 \%$ (mean deviation, $1 \sigma$ ), which translates to a standard deviation of $16.7 \%(2 \sigma)$. Uses global average ${ }^{85} \mathrm{Rb} /{ }^{87} \mathrm{Rb}$ value $(2.58745)$ for isobaric $\mathrm{Rb}$ interference.

${ }^{87} \mathrm{Sr}{ }^{86} \mathrm{Sr}$ and $\mathrm{Rb} / \mathrm{Sr}$ values obtained by conventional methods (XRF or ICP) are reported in Workmanet al ., 2004 [7].

${ }^{\mathrm{h}}$ Raw voltages on mass 82 divided by mass 88 . This is a proxy for $\mathrm{Kr} / \mathrm{Sr}$ during analysis

'Samples are run at less than $100 \%$ laser power (between $45-90 \%$ power)

¡Unlike all other Samoan glass standard and melt inclusion analyses, these four analyses were performed with a "dry" plasma (i.e., no aspiration of the $5 \%$ nitric solution during laser analysis).

These dry runs are not used in calculations or in the figures, and were performed for comparative purposes only. We find that the $\mathrm{Rb}$ is strongly fractionated from $\mathrm{Sr}$, and that th $\epsilon^{85} \mathrm{Rb}{ }^{87} \mathrm{Rb}$ required

and mass bias tend to me lower than similar runs made with a wet plasma during the same analytical session.

${ }^{\mathrm{k}}$ The amount of mass bias correction required to obtain the canonical value for ${ }^{86} \mathrm{Sr} /{ }^{88} \mathrm{Sr}$. Units are $\% / a m u$.

'External precision is calculated assuming that the $\mathrm{TIMS}^{87} \mathrm{Sr}{ }^{86} \mathrm{Sr}$ is correct. External precision is calculated using the "bracketing" technique for the correction of the isobaric interference from Rb on mass 87. The external precision is somewhat improved (127 ppm, 1 mean deviation) compared to the global average technique for the Rb correction (155 ppm) when comparing the same set of glass analyses.

Bracketing is a useful technique for individual, 1-day analytical sessions only, as ${ }^{85} \mathrm{Rb} /{ }^{87} \mathrm{Rb}$ values can change significantly between analytical sessions. Therefore,

the first and last runs of the Samoan glass standards of each analytical session cannot be corrected with the bracketing technique. Runs with a dry plasma are not examined.

${ }^{\mathrm{m}}$ Same as previous column, but ${ }^{87} \mathrm{Sr}{ }^{86} \mathrm{Sr}$ values calculated by correcting for the $\mathrm{Rb}$ interferece using the "bracketing method", our preferred correction scheme and the one adopted in the manuscripl

for correcting unknowns. 
Table 5. Compositions of Samoan glasses ("standards") used in determining ${ }^{85} \mathrm{Rb} /{ }^{8 /} \mathrm{Rb}$ required values in this study.

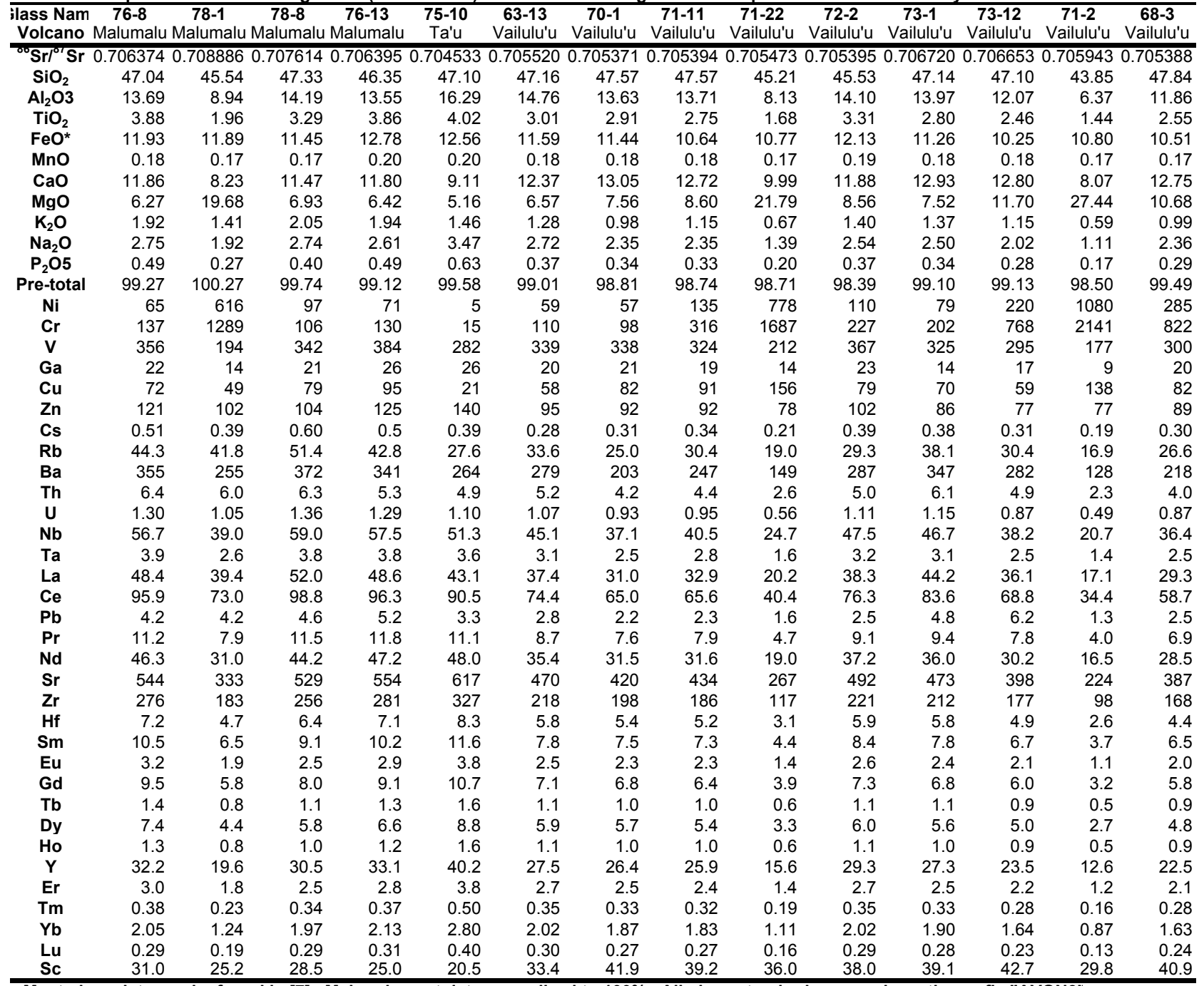

Most glass data can be found in [7]. Major element data normalized to $100 \%$. All glass standards names have the prefix "AVON3" 


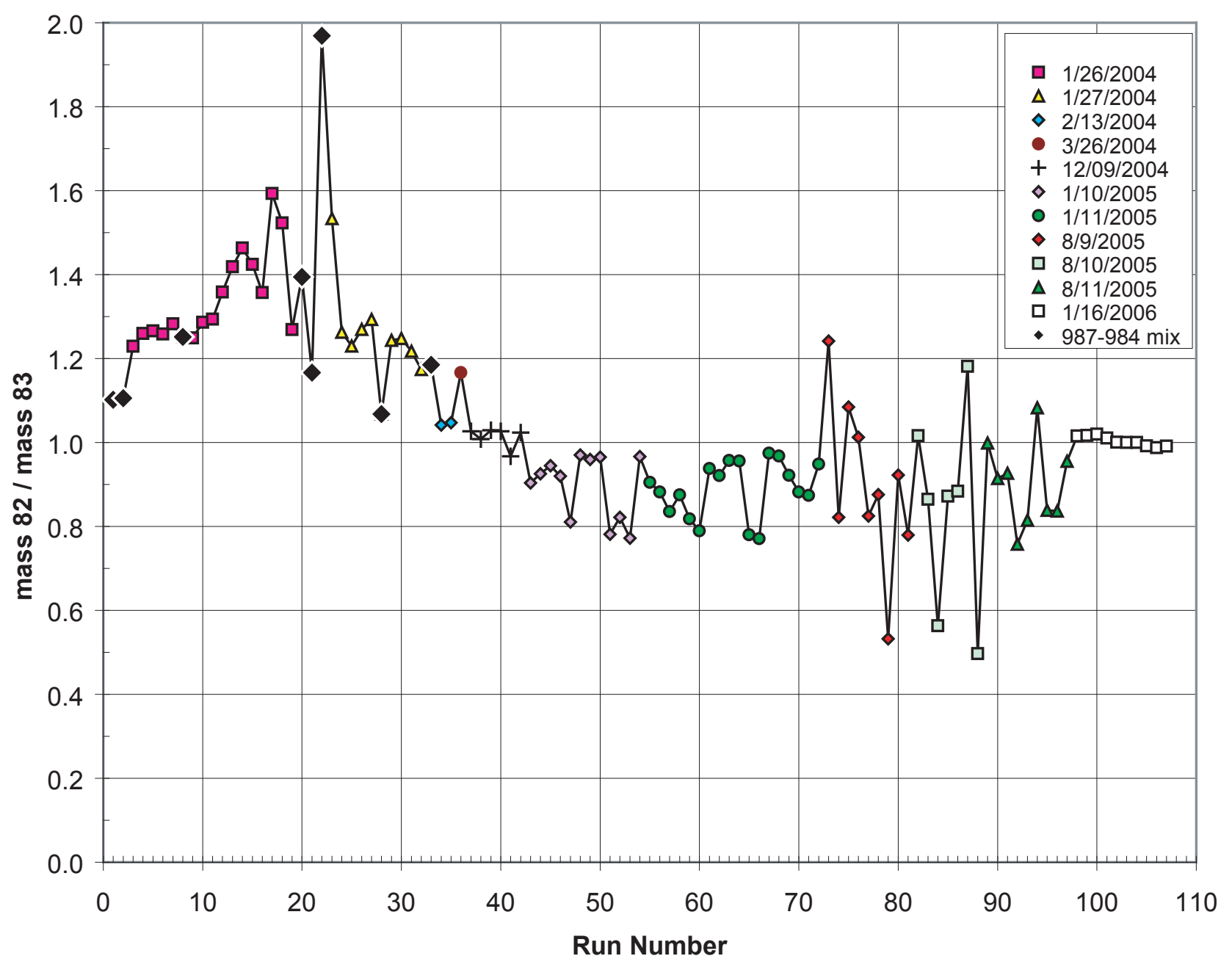

Fig. 1 


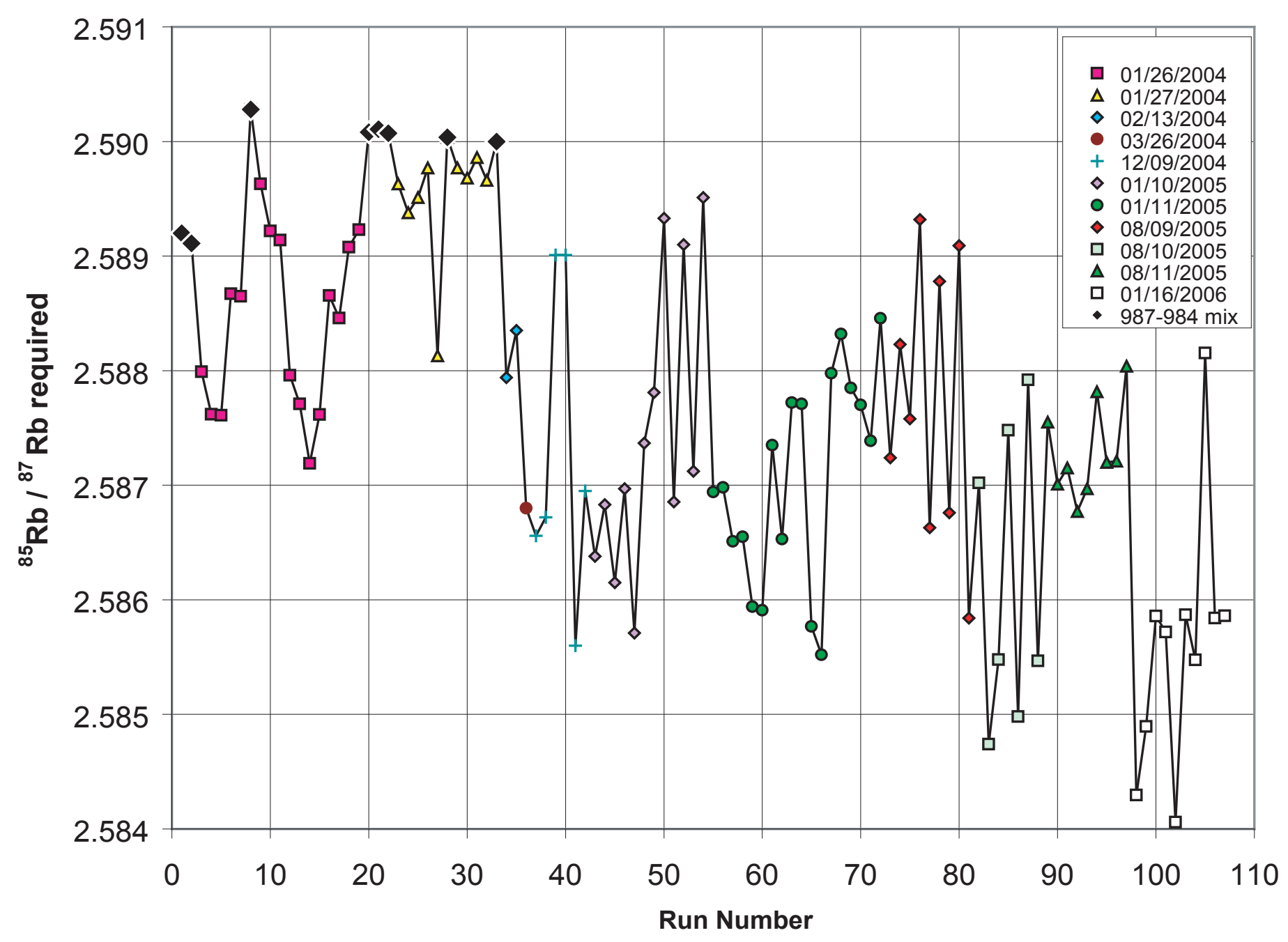

Fig. 2 


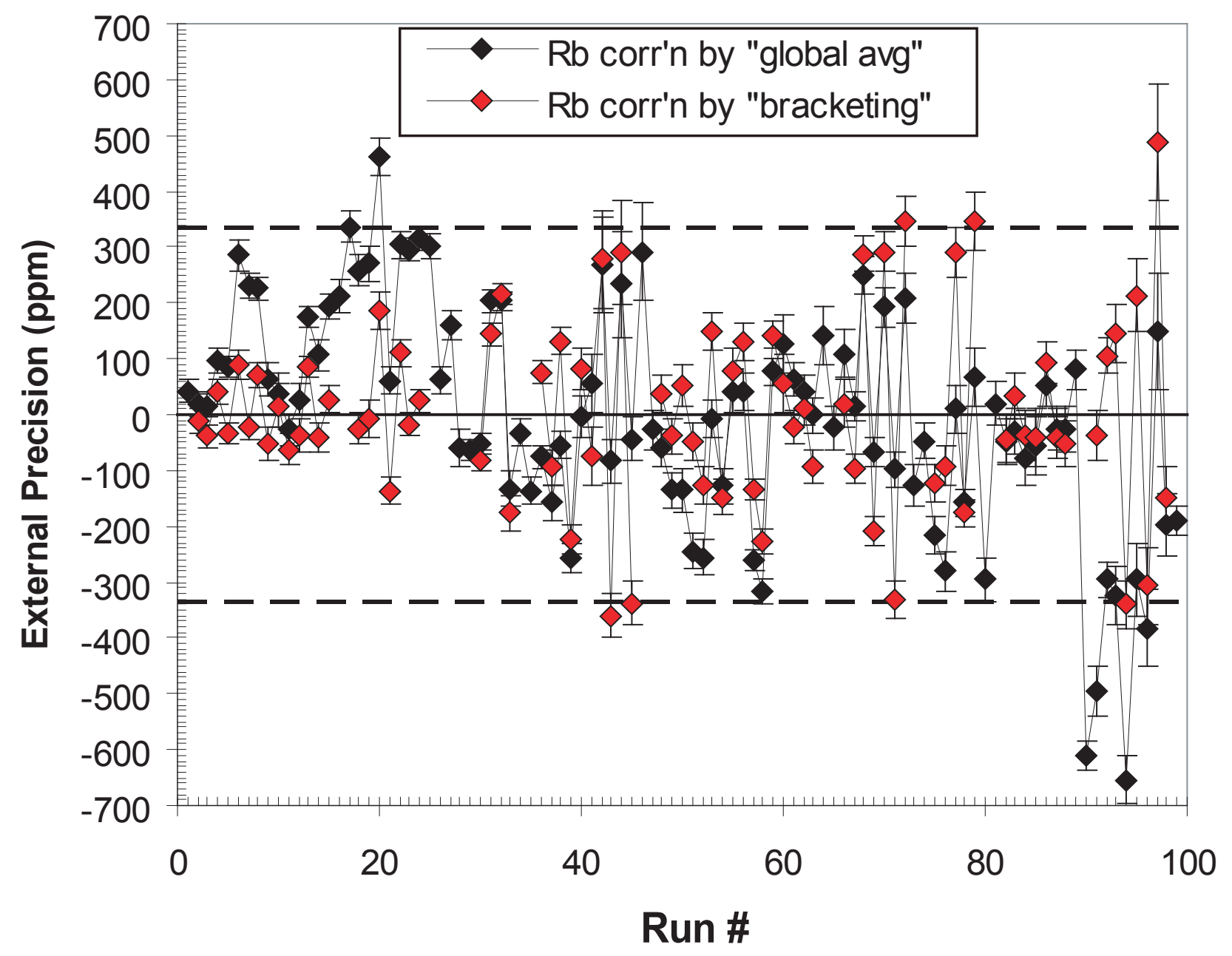

Fig. 3 


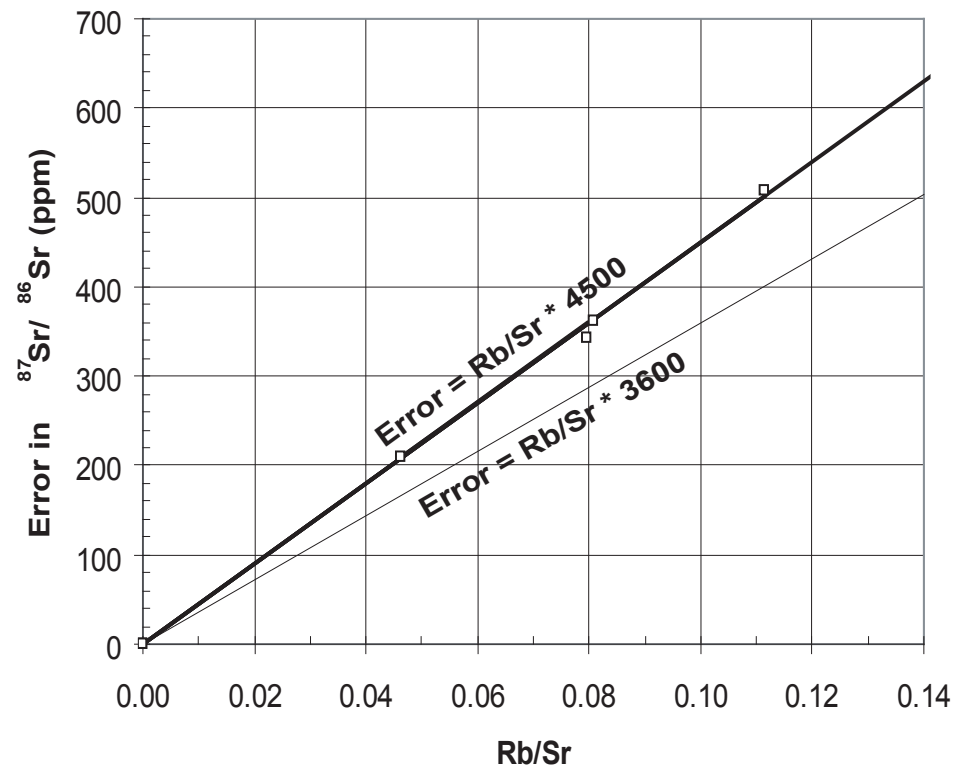

Supp Data Fig. 4 


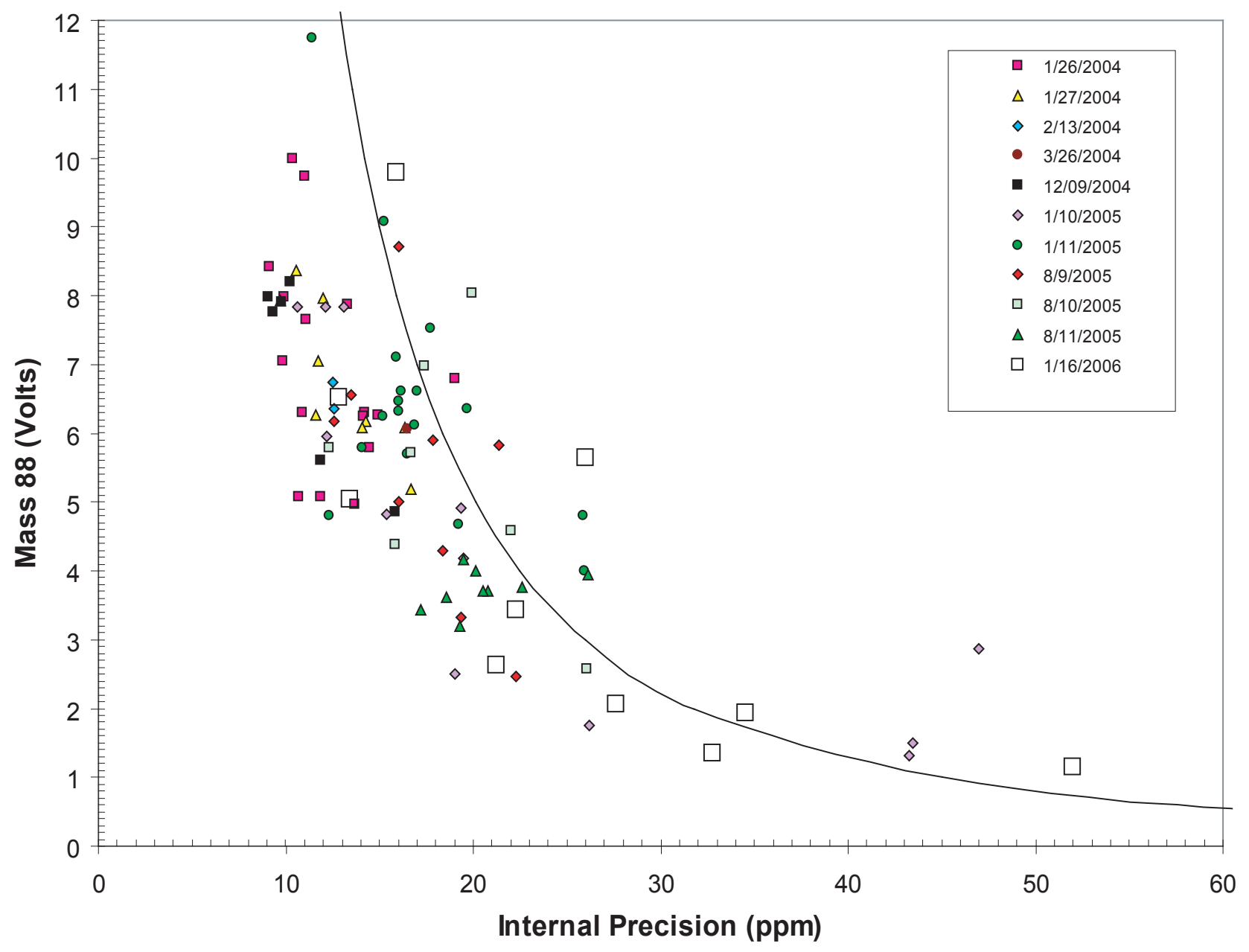

Fig. 5 


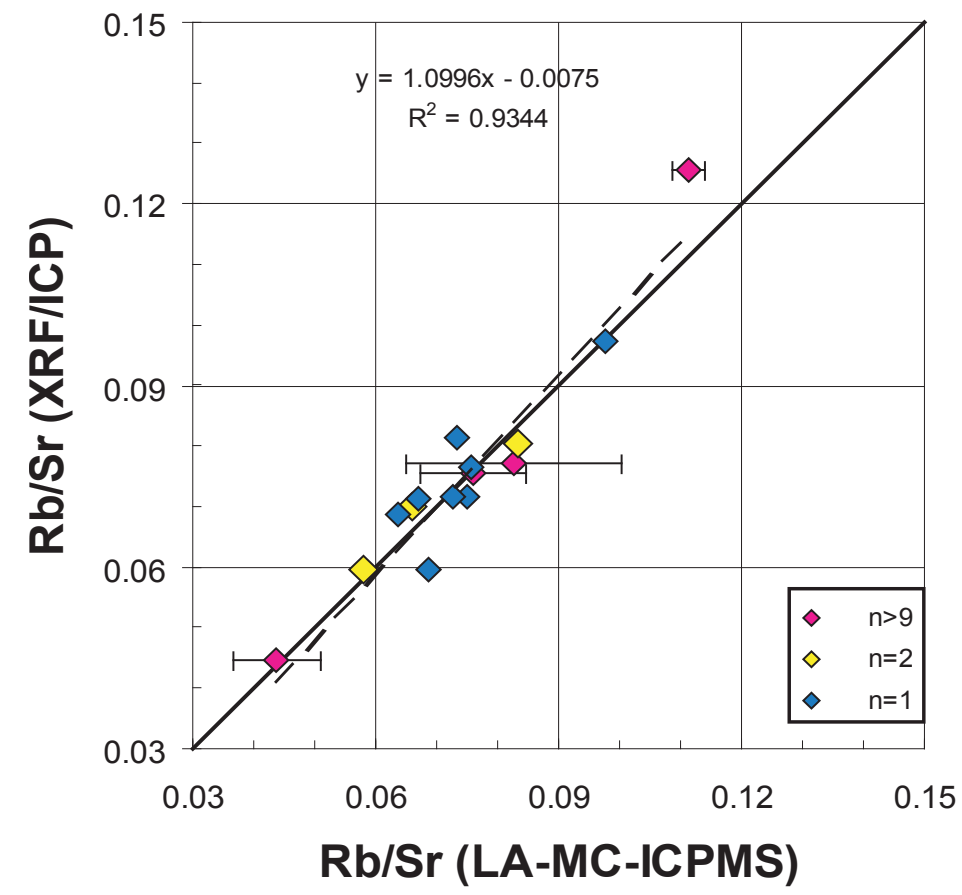

Fig. 6 